UNIVERSIDADE DE SÃO PAULO

INSTITUTO DE GEOCIENCIAS

\title{
ESTUDO DA REABILITAÇÃO DE SOLOS EM ÁREAS BAUXÍTICAS MINERADAS EM POÇOS DE CALDAS (MG): UMA ABORDAGEM AMBIENTAL E UMA CONTRIBUIÇÃO TÉCNICA PARA OTIMIZAÇÃO.
}

lara Weissberg

Orientadora: Profa. Dra. Maria Cristina Motta de Toledo

TESE DE DOUTORAMENTO

Programa de Pós-Graduação em Geoquímica e Geotectônica 


\section{UNIVERSIDADE DE SÃO PAULO INSTITUTO DE GEOCIENCIAS}

\section{ESTUDO DA REABILITAÇĀO DE SOLOS EM ÁREAS BAUXÍTICAS MINERADAS EM POÇOS DE CALDAS (MG): UMA ABORDAGEM AMBIENTAL E UMA CONTRIBUIÇÃO TÉCNICA PARA OTIMIZAÇĀO.}

lara Weissberg

Orientadora: Profa. Dra. Maria Cristina Motta de Toledo

TESE DE DOUTORAMENTO

COMISSÃO JULGADORA

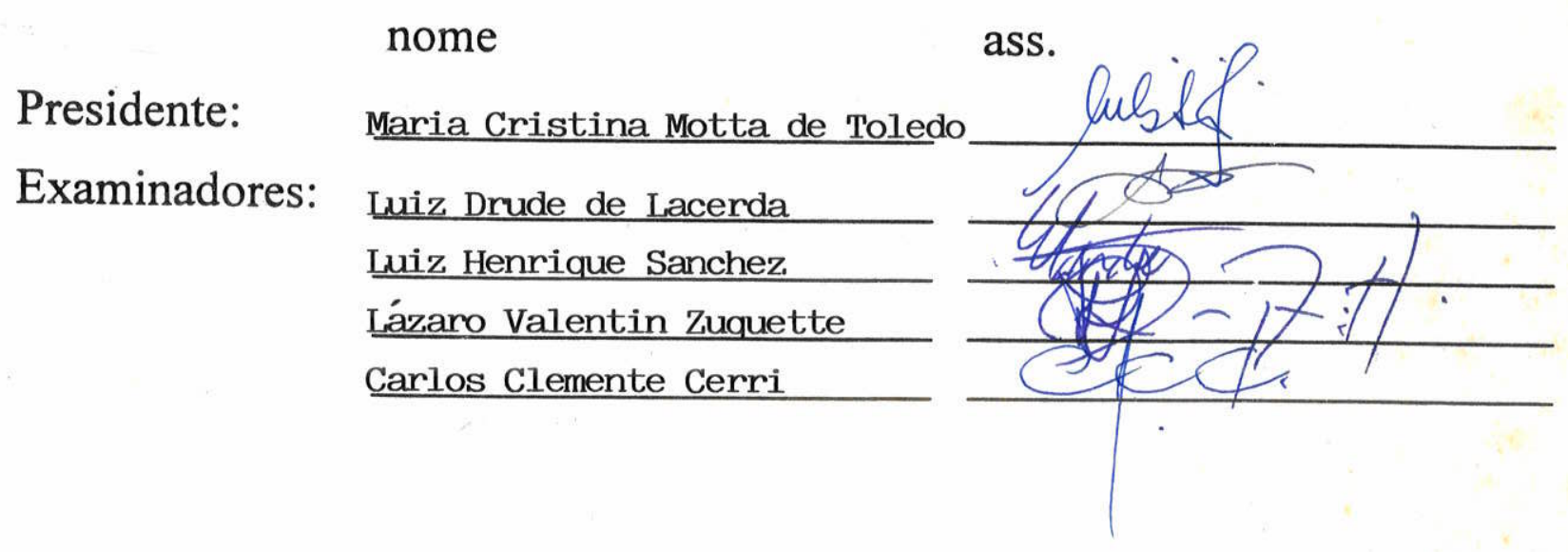






\section{ESTUDO DA REABILITAÇAO DE SOLOS EM AREAS BAUXÍTICAS MINERADAS EM POÇOS DE CALDAS (MG): UMA ABORDAGEM AMBIENTAL E UMA CONTRIBUIÇÃO TÉCNICA PARA OTIMIZAÇÃO.}

lara Weissberg

Orientadora: Profa. Dra. Maria Cristina Motta de Toledo

\section{TESE DE DOUTORAMENTO}

Programa de Pós-Graduação em Geoquímica e Geotectônica

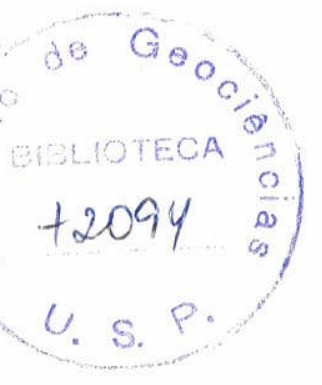

São Paulo 1995 
RESUMO

ABSTRACT

CAPITULOO 1 - ORIGEM DA PESQUISA

1.1. INTRODUÇÃO

1.3. OBJETIVOS

1.2. REVISÃO BIBLIOGRÁFICA

CAPÍTULO 2 - CARACTERIZAÇÃO DA ÁREA DE ESTUDO

2.1. GEOLOGIA

2.2. GEOMORFOLOGIA, CLIMA E VEGETAÇÃO

2.3. RECURSOS HIDRICOS

2.4. SOLOS

2.5. MINERAÇÃO

CAPÍTULO 3 - METODOLOGIA

3.1. MATERIAIS ESTUDADOS

3.2. MÉTODOS DE ESTUDO

3.3. EXPERIMENTO DA SOLUBILIDADE DO ALUMÍNIO

CAPÍTULO 4 - RESULTADOS OBTIDOS E DISCUSSÕES

4.1. ESTUDO DOS PERFIS

4.1.1. PERFIS DE SOLOS NATURAIS

4.1.2. PERFIS DE SOLOS NOVOS

4.1.3. DISCUSSÕES PARCIAIS 
4.2. CARACTERIZAÇÃO DOS MATERIAIS

4.2.1. ESTUDOS FISICOS, QUIMICOS, FISICO-QUIMICOS E MINERALÓGICOS DOS MATERIAIS

4.2.1.1. pH, UMIDADE RESIDUAL, CARBONO, MATERIA ORGÂNICA, TEXTURA E MINERALOGIA DOS SOLOS

4.2.1.2. DISCUSSÖES PARCIAIS

4.2.2. ESTUDOS MICROMORFOLÓGICOS E MICROGEOQUIMIICOS

4.2.2.1. MICROSCOPIA ÓPTICA

a) Estudo microscópico dos solos naturais

b) Análise de imagem de solo

86

c) Estudo microscópico dos solos novos

88

90

4.2.2.2. OBSERVAÇŌES E ANÁLISES AO M.E.V. - EDS 94

4.2.2.3. ESTUDOS MICROGEOQUÍMICOS À M.E 94

4.2.2.4. DISCUSSÕES PARCIAIS

4.3. RESULTADOS DA SOLUBILIDADE DO ALUMINIO

4.3.1. DISCUSSÖES PARCIAIS

CAPÍTULO 5 - CONCLUSÕES E SUGESTÕES TÉCNICAS

5.1. CONCLUSÖES

5.2. SUGESTÕES TÉCNICAS

REFERENNCIAS BIBLIOGRÁFICAS 


\section{INDICE DE FIGURAS}

Figura 1. Mapa da localização do Maciço Alcalino de Poços de Caldas

Página

03

Figura 2. Planta da Cidade de Poços de Caldas com as áreas de pesquisa 04 de concessão à ALCOA

Figura 3. Mapa Geológico de Poços de Caldas e região segundo Ellert, 19 1959.

Figura 4. Desenho esquemático do manto de alteração com os bolsões bauxíticos e o corte de lavra

Figura 5. Gráfico da Pluviometria nas áreas de estudo

Figura 6. Esquema do Equipamento para o Experimento de Solubilidade do 43 Alumínio

Figura 7. Perfil descritivo da foto $8 \mathrm{~F}$

Figura 8. Perfil descritivo da Foto $8 \mathrm{G}$

63

Figura 9. Diagramas de Textura dos solos: Diagrama 1 - Área 1; Diagrama 2 - Área 2 reabilitada há 3 anos; Diagrama 3 - Área 2 reabilitada há 6 anos; 74

Diagrama 4 - Área 3; Diagrama 5 - Área 4 reabilitada há 6 anos; Diagrama 6 - Área 5 reabilitada há 7 meses

Figura 9A - Gráfico do estudo do efeito da textura na capacidade do solo de reter água (USDA 1961)

Figura 9B - Diagrama da Textura dos Solos (Associação Internacional de Solos) 
Figura 10.Diagramas de Textura dos Solos: Diagrama 7 - Área 5 reabilitada

há 2 anos; Diagrama 8 - Área 5 reabilitada há 3 anos; Diagrama 9 - Área 6 reabilitada há 15 anos; Diagrama 10 - Área 7 reabilitada há 7 meses; Diagrama 11 - Área 7 reabilitada há 2 anos; Diagrama 12 - Área 8 área-piloto após 7 meses

Figura 11 - Diagramas de Textura do Solos: Diagrama 13 - Área 8 revegetada há 7 meses; Diagrama 14 - Área 8 reabilitada com serapilheira há 3 anos;

Diagrama 15 - Textura do "top-soil" - página

Figura 12 - Gráfico das medidas de pH nas áreas estudadas

80

Figura 13 - Gráfico das medidas de Carbono nas áreas estudadas

Figura 14 - Gráfico das medidas de Matéria Orgânica Total nas áreas estudadas

Figura 15 - Gráfico de Umidade Residual das áreas estudadas

Figura 16 - Difratograma típico das análises de Difração de Raio $X$ dos solos

Figura 17 - Imagem analisada com uso de cores pelo SITIM

Figura 18 - Diagramas da Composição Mineralógica: Diagrama M.1 - 17 pontos em lâmina de solo natural da Área 1, profundidade $7-10 \mathrm{~cm}$; Diagrama M.2 - 4 pontos de lâmina de solo natural da Área 1, profundidade $35-40 \mathrm{~cm}$

Figura 19 - Diagramas da Composição Mineralógica: Diagrama M.3 - 15 pontos em lâmina de solo novo da Área 2, profundidade $7-10 \mathrm{~cm}$; Diagrama M.4 - 32 pontos da lâmina de solo novo da Área 6, profundidade $6-15 \mathrm{~cm}$

Figura 20 - Diagrama da Composição Mineralógica: Diagrama M.5 - 12 pontos em lâmina de solo novo da Área 8 revegetada, profundidade $2-10 \mathrm{~cm}$; Diagrama M.6 - 11 pontos em lâmina de solo novo da Área 8 sem vegetação (área-piloto), profundidade 2-10cm; Diagrama M.7 - 3 pontos com vegetação, profundidade $43 \mathrm{~cm}$ 
Figura 21 - Espectros EDS: Espectro EDS-1 - análise de partículas 104 arredondadas (imagem da foto 20); Espectro EDS-2 - análise de cristal alongado (imagem do substrato - placas, cristais alongados e romboédricos); Espectro EDS - 3 análise do substrato através de uma linha horizontal no centro da foto 22 


\section{INDICE DE FOTOGRAFIAS}

Foto 1 - Área 1 Vegetação de campo cerrado

Página

Foto $1 \mathrm{~A}$ - Perfil aberto na Área 1 50

Foto 2 - Área 2 revegetada há 3 anos 50

Foto $2 \mathrm{~A}$ - Experiência com serapilheira na Área 2 50

Foto 2B - Área 2 com capim-gordura seco 50

Foto 3 - Área 3 vegetação de floresta subtropical 53

Foto 3 A - Perfil aberto na Área 3

Foto 4 - Área 4 reabilitada há 6 anos com Bracaatinga 53

Foto $4 A$ - Perfil no interior da Área 4 com capim-gordura seco 53

Foto 4B - Perfil na borda da Área 4

Foto 5 - Área 5 reabilitada há 7 meses

Foto $5 \mathrm{~A}$ - Área 5 reabilitada com capim-gordura há 2 anos

Foto 5B - Área 5 reabilitada há 3 anos com Cassia speciosa há 1 ano

Foto 6 - Área 6 reabilitada há 12 anos com eucalipto

Foto 7 - Área 7 reabilitada há 7 meses

Foto 7A - Perfil aberto na Área 7 com 7 meses

Foto 7B - Área 7 reabilitada há 3 anos com semeagem de Cassia speciosa há 1 ano 
Foto 7C - Perfil aberto na Área 7 com Cassia speciosa

Foto 8 - Área 8 após preparo da superficie, parte subsolada, parte não

Foto $8 \mathrm{~A}$ - Área 8 na sub-área que recebeu serapilheira ( 1 a sub-área)

Foto $8 \mathrm{~B}$ - Área 8 mostrando parte da sub-área com capim-gordura em contato com a área-piloto após 7 meses

Foto $8 \mathrm{C}$ - Áre 8 mostrando parte da sub-área com capim-gordura em contato com a área piloto após 2 anos

Foto 8D - Área 8 na $3^{2}$ sub-área (sem capim-gordura nem serapilheira)

Foto $8 \mathrm{E}$ - Áre 8 na $1^{a}$ sub-área com várias espécies secundárias (da 61 serapilheira) e mudas (do viveiro) após 3 anos

Foto 8 F - Perfil na área-piloto após 2 anos

63

Foto $8 G$ - Perfil na 2a sub-área (com capim-gordura) há 2 anos

Foto 9 - Imagem da lâmina de solo natural de campo cerrado ao microscópio com luz natural

Foto 9A - Mesma imagem da foto anterior com luz parcialmente polarizada

Foto 10 - Imagem da lâmina de solo natural de floresta na profundidade entre $2-10 \mathrm{~cm}$ com luz natural

Foto $10 \mathrm{~A}$ - Mesma imagem com luz parcialmente polarizada

Foto 11 - Imagem da lâmina de solo natural na profundidade entre $10-15 \mathrm{~cm}$ com luz natural

Foto $11 \mathrm{~A}$ - Mesma imagem com luz parcialmente polarizada 
Foto 12 - Imagem de revestimento de fissura numa lâmina de solo novo da Área 7 após 7 meses

Foto 13 - Imagem de fissura modificada em plasma não reativado da Área 2 92 após 3 anos

Foto 13A - Mesma imagem com luz polarizada 92

Foto 14 - Imagem de vazio em forma de cunha (vazio novo) da Área 8 revegetada há 2 anos

Foto 14A - Mesma imagem com luz polarizada

Foto 14B - Mesma imagem com luz polarizada e cunha de gipso

Foto 15 - Imagem de plasmas diferentes, um não reativado com antigas 93 fissuras modificadas e outro reativado com luz natural

Foto 15B - Mesma imagem com luz polarizada e cunha de quartzo

Foto 16 - Imagem de tres plasmas diferentes, um reativado, outro preto com cristais bem desenvolvidos e outro parcialmente reativado com luz natural

Foto $16 \mathrm{~A}$ - Mesma imagem com luz polarizada e cunha de gipso

Foto 17 - Imagem de solo novo apresentando fissuras novas dentro dos plasmas e revestidas por cristais bem desenvolvidos com luz polarizada

Foto $17 \mathrm{~A}$ - Mesma imagem com cunha de gipso

Foto 18 - Agregado do solo natural de floresta

Foto 19 - Bloco do substrato pós-minerado

Foto 20 - Imagem do MEV de fragmento do agregado ampliada 2.000 vezes

Foto 21 - Imagem do MEV de fragmento do bloco de substrato ampliada 3.500 
Foto 22 - Imagem do MEV de fragmento do bloco de substrato ampliada 5.000 vezes 


\section{INDICE DE TABELAS}

Tabela 1 - Análise dos nutrientes dos materiais usados na reabilitação

Página

Tabela 2 - Áreas de Estudo

Tabela 3 - Preparo típico de sementes e fertilizantes para as partes 32 horizontais das bancadas e para os taludes das bancadas

Tabela 4 - Preparo típico das covas que recebem as mudas para revegetação

Tabela 5 - Relação das espécies vegetais nativas que estão sendo desenvolvidas no viveiro

Tabela 6 - Características dos materiais da Área 1

Tabela 7 - Características dos materiais da Área 2

Tabela 8 - Caracteristicas dos materiais da Área 3

Tabela 9 - Características dos materiais da Área 4

Tabela 10 - Caracteristicas dos materiais da Área 5

Tabela 11- Características dos materais da Área 6

Tabela 12 - Características dos materiais da Área 7

Tabela 13 - Características dos materiais da Área 8

Tabeal 14 - Resultados das análises à M.E. - Área $1(0-7 \mathrm{~cm})$

Tabela 15 - Resultados das análises à M.E. - Área $1(33-40 \mathrm{~cm})$

Tabela 16 - Resultados das análises à M.E. - Área 2 
Tabela 18 - Resultados das análises à M.E. - Área 8 revegetada

Tabela 19 - Resultados das análises à M.E. - Área 8 s/ vegetação

Tabela 20 - Resultados das análises à M.E. - Área $8(40-46 \mathrm{~cm})$

Tabela 21 - Resultados das análises de solubilidade do aluminio após $24 \quad 107$ horas

Tabela 22 - Resultados das análises de solubilidade do alumínio após $168 \quad 108$ horas

Tabela 23 - Resultados das análises de disponibilidade de Al+++ e $\mathrm{H}+$ no solo da Área 8 revegetadas

Tabela 24 - Resultado das análises de Al+++ e H+ na Área 8 s/ vegetação 


\section{AGRADECIMENTOS}

Ao Museu Paraense Emílio Goeldi, instituição de pesquisa da qual faço parte, pelo apoio durante os últimos 12 anos de trabalho.

Ao Instituto de Geociências da Universidade de São Paulo. estudadas.

A ALCOA pelo apoio logístico no campo e pelo acesso às informações sobre as áreas

Ao CENA-USP pela realização de análises de solos.

Ao CEPAS pelo apoio.

A Universidade Federal da Bahia pelos trabalhos realizados no Laboratório de Microssonda Eletrônica. estudos.

Ao Conselho Nacional de Desenvolvimento Científico e Tecnológico pela bolsa de

A minha orientadora, Profa. Maria Cristina Toledo que muito colaborou com idéias e conduzindo os trabalhos de maneira muito franca e amiga.

Ao Prof. A. Mermut da Universidade Saskatchewan, Saskatoo, Canadá, que me incentivou na busca de métodos alternativos para a pesquisa.

Ao Geólogo Don Williams, que mais que um colega, foi um incentivador da pesquisa quando o dinheiro do projeto acabou.

Ao Prof. Cartos Cerri pela ajuda nas análises de solos. informações.

Ao Agrônomo Cleyton Ferreira Morais pela ajuda nos trabalhos de campo e pelas

Ao Prof. Michael Heath da Universidade de Exeter, Inglaterra, que acreditou na minha pesquisa e colaborou enviando publicações inglesas no campo de estudo. sugestões.

Ao Pesquisador René Boulet da ORSTOM, França, pelo apoio nas pesquisas e pelas

Ao Prof. José Vicenti Valarelli, pela ajuda na busca de auxílio para a pesquisa e pelo apoio a pesquisa com sugestões e idéias sempre oportunas.

Ao Prof. Aldo da Cunha Rebouças pelo apoio geral.

A Profa. Selma Simões de Castro pela ajuda no organização dos meus trabalhos de estudo dos perfis de solo e nas observações de lâminas de solo.

Aos técnicos do Instituto de Geociências: Sueli, Cleide, Mário, Verônica e outros que ajudaram muito no preparo de amostras e nas análises de laboratório.

Aos meus filhos Michel e Sarah pela paciência e pelo apoio durante este periodo difícil. Aos meus pais.

A memória de Oscar do Amaral Neto, meu companheiro de muitos anos.

A todos aqueles que de uma maneira ou de outra colaboraram com idéias e sugestões para este trabalho. 


\section{RESUMO}

A região bauxítica de Poços de Caldas vem sendo minerada por várias empresas e, nos últimos 10 anos, com a exigência dos orgãos ambientais, as áreas mineradas estão sendo reabilitadas (revegetadas) com o emprego de diferentes procedimentos de preparo do solo e de plantio usando várias espécies vegetais.

Foram escolhidas algumas destas áreas, com diferentes idades de reabilitação, para compor o campo do presente estudo que objetivou, através de comparação entre os vários resultados obtidos $e$ as observações relativas ao desenvolvimento da vegetação e dos solos, reconhecer a evolução da reabilitação dos solos novos para propor procedimentos mais apropriados para o êxito dos trabalhos que buscam reintegrar as áreas mineradas à paisagem natural.

As técnicas de preparo do terreno colocam à superfície materiais que anteriormente estavam em profundidade, iniciando um novo processo pedogenético relacionado ao clima da região. Apesar destas ações naturais sobre os materiais, a adição de fertilizantes, de "top-soil", a sulcagem da superficie e as espécies vegetais escolhidas para cobrir as áreas influem, por sua vez, de modo a acelerar os processos naturais. Os resultados desta pesquisa evidenciaram a importância de procedimentos que permitam a rápida reestruturação dos solos para sucesso da reabilitação.

O estudo dos teores de carbono orgânico e matéria orgânica mostrou que a estruturação dos solos, fenômeno importantíssimo para as funções de ciclagem de nutrientes para a biota associada à planta, ocorre em presença de teores mínimos desta matéria orgânica. As áreas que apresentaram melhor desenvolvimento da vegetação continham valores acima de $2 \%$ de carbono e de $2,5 \mathrm{~g}$ de matéria orgânica total em cada $50 \mathrm{~g}$ de solo ou seja $5 \%$. Entretanto a erosão mostrou-se muito atuante nas meia-encostas onde está a maioria das áreas mineradas, como foi medido nas análises de granulometria e na evolução da textura das áreas. Desta maneira a matéria orgânica pode ser perdida muito facilmente. Por isto a escolha da vegetação é muito importante uma vez que o desenvolvimento rápido de raizes ajuda a fixar os materiais mais finos que se aglutinam com a participação da matéria orgânica e da água que está nas raízes e pelo fenômeno da osmose passa para fora.

$O$ estudo microestrutural dos solos permitiu visualizar o arranjo geral dos seus componentes e a disposição dos poros, permitindo uma classificação evolutiva dos solos naturais em relação aos novos. O estudo microgeoquímico à microssonda eletrônica contribuiu para identificação do processo geoquímico que ocorre com o revestimento dos poros, talvez ampliado pelas substâncias adicionadas no preparo das áreas para a revegetação. Nos solos naturais, os revestimentos de poros são principalmente ferruginosos, enquanto que nos solos novos, principalmente gibbsíticos. Neste aspecto, o estudo mostrou que o mecanismo de gibbsitização, 
responsável pela formação das jazidas da área, continua ocorrendo, sob ação da pedogênese, nos materiais retrabalhados pela reabilitação, e em curto intervalo de tempo.

Os minerais secundários predominantes nestes solos são a gibbsita, a caulinita e a goethita. Os solos naturais apresentam um estágio evolutivo muito adiantado com fissuras interconectadas a grandes fissuras no interior das quais aparecem microagregados ricos em matéria orgânica. Os solos novos apresentam esta evolução fissural muito modificada na forma com revestimento por materiais remobilizados. Este aspecto pode estar relacionado ao desenvolvimento precário da vegetação em algumas áreas, além dos tratamentos artificiais.

A importância da reabilitação de áreas mineradas reside não somente na fixação da vegetação mas também no desenvolvimento pedológico dos materiais. Os solos assim desenvolvidos passam a reduzir a atividade das águas de chuva não só na erosão mas também na dissolução de elementos ou substâncias tóxicas existentes nos materiais descartados pela mineração. A passagem para os recursos hidricos superficiais ou subterrâneos destas substâncias ou íons tóxicos podem atingir tanto a vegetação como os animais $e$, no caso de cidade próxima, a população. Um experimento realizado com solo e bauxita mostrou que uma camada de solo reduziu a teores abaixo dos limites de detecção a solubilidade do alumínio, que, em contato direto com água, seria solubilizado. 


\section{ABSTRACT}

Mining companies in the region of Poços de Caldas has been exploiting bauxiteand in the last ten years, obeying environmental agency exigencies, mined areas have been rehabilitated by different material preparation and plantation of selected vegetal species.

Natural areas and several rehabilitated areas of different ages were chosen for the study. By comparison of the data obtained and observations on soil evolution and plant growth, the rehabilitation process on new soils was analysed. The aim was to propose the best methods which could return these areas, in the time, to the state of the natural landscape.

The preparation techniques place on the surface materials which were present in deeper points of the natural soil profile. The obtained data shows that climatic action modifies the preparation. Fine materials are eroded, and the regional pedogenetic processes initiates modification within the new top-soil. Besides this natural action, some artificial improvements occur through use of fertilizers and addition of stored original top-soil. Deep and straight furrows have been opened, by ripper equipment, crossing the land surfaces and special vegetal species were seeded and planted to cover these areas. All these actions were efforts to accelerate the rehabilitation.

Comparing the measures of Carbon and Organic Matter in the natural and new soils and the evolution of soil structuring by roots of plants, it was possible to conclude that a small quantity of these substances $10.2 \%$ of Carbon or $0.5 \%$ of total Organic Matter) is enough to start soil structuring in presence of vegetation development. Natural soils in areas which presented the best vegetation development contained $2 \%$ of Carbon and $5 \%$ of Organic Matter.

On the other hand, erosion was stronger in the rehabilitated areas because they are on inclined relief. Carbon and organic matter are eroded together with the fine particles of soils. Because of this, the choice of grass species is very important. The "capim gordura" is a good option because it covers the surface very rapidly, its roots contribute to the structuring of soils and consequently it helps to retain fine particles
and associated organic matter.

The most important minerals in these soils are gibbsites, kaulinites and goethites. The microscopic studies on the natural soils presented a well-evolved agglomeroplasmic microstructure or interconnected fissural system, with rounded particles, while new soils presented this fissural system but with modified particle
shapes or with coatings of remobilized materials.

Aluminum solubility was studied by a laboratory lixiviation experiment of water percolation through bauxite and soil. The results showed the soil to be a system with
low water activity.

In conclusion, soil rehabilitation is important to integrate mined areas into the landscape and to reduce the solubility of toxic elements. 


\section{ORIGEM DA PESQUISA}

\subsection{INTRODUÇÃO}

Esta pesquisa começou em dezembro de 1982, numa visita feita ao Projeto Ferro Carajás, Marabá-Pará. Conhecendo o que era a polêmica do momento, foi possivel sentir bem de perto o que é a Floresta Amazônica. Dentro da mata, coletando amostras de água em vários igarapés da região, foi possivel sentir o que significa uma floresta tropical úmida: as árvores imensas com flores multicores, outras com frutos e quase todas portando bromélias e orquídeas floridas. Como seria bom entender um pouco daquela diversidade de espécies vegetais, do solo que tem um tapete espesso de materiais caídos das árvores que chamava a atenção porque dificultava andar. A vegetação e o solo parecem ser um, continuidade do outro.

Os animais eram vários, que apareciam em muitos pontos, desde os insetos de cores e tamanhos variados, andando em grupos ou isolados, até a enorme onça pintada, além das belas araras de cores exuberantes. Todo este contexto chamou a atenção para uma harmonia evidente. Todas aquelas formas de vida estavam interagindo sobre o solo que lhes dá suporte e alimento, mantidos por um clima onde a água está presente abundantemente em dois estados, vapor e liquido. A temperatura é alta e constante e a ausência de brisa predomina neste contexto. Os igarapés e os riachos são de água muito límpa onde uma intensa vida aquática é uma atração a parte.

Este contato de dez dias atravessando montanhas de matas fechadas e campos de vegetação aberta, tiveram como objetivo coletar amostras de água. Lagos formados sobre as depressões na superfície da canga limonítica sobre os platôs elevados são recursos hídricos importantes porque desenvolvem os processos dinâmicos de um lago vivo com a presença de jacarés, capivaras e antas às margens.

Um aroma diferente era a mistura de vapor de água, transpiração das plantas e perfume das flores sentido em todos os pontos. Era o primeiro contato com o equilibrio ecológico numa região tão peculiar. Apesar de todas as observações, o objetivo da 
viagem foi conhecer as características das águas da região, direta ou indiretamente afetadas pelas modificações decorrentes da implantação do Projeto Fero Carajás.

Este projeto previa a fixação de 20 mil pessoas, mas a quantidade de trabalhadores já quase atingia este número. A Cia. Vale do Rio Doce estava se instalando na Amazônia para explorar o minério de ferro dentre outros minérios que ocorrem no contexto geológico da região.

Foi então, em contato com os trabalhos de instalação do Projeto Carajás que se sentiu o que significa modificar profundamente a paisagem ou modificar as condições de equilibrio de um ecossistema que participa de um geossitema rico em minérios de alto teor e boa qualidade tecnológica.

Muitas árvores já tinham dado lugar às moradias coletivas e residências isoladas, estradas e taludes em vias de revegetação, e a vegetação própria da canga de limonita já estava parcialmente retirada sendo substituida por escritórios e toda a infraestrutura de apoio a mineração.

A expectativa criada por um empreendimento de grande porte como este, fez com que pessoas sem emprego se vissem atraídas pela esperança de alguma colocação. Por outro lado muitas pessoas que foram para Amazônia em busca de ouro, que ocorre nos aluviões dos vários igarapés e rios, se instalaram nas proximidades, ainda mais considerando que a área do projeto está a pouco mais de cem quilômetros de Serra Pelada. Formou-se uma enorme favela, ou uma cidade sem infraestrutura semelhante às do velho oeste dos Estados Unidos. As modificaçōes do ambiente foram evidentes, sem condições de controle por parte dos orgãos do governo ou da própria empresa mineradora.

Os garimpeiros, que foram os primeiros habitantes, chegaram e se instalaram em pontos ainda intactos e provocaram uma forte modificação da paisagem, arrasando - leito dos rios e deixando um rastro de destruição da floresta, com marcas profundas. O leito de alguns igarapés se transformaram numa sequência de buracos porque o aluvião foi revolvido para separar o ouro do cascalho. Com a chegada das chuvas esses buracos se transformaram em criadouros de mosquitos, alguns transmissores de malária, o que levou esta doença a ser endêmica nesta região.

Esta destruição ambiental descontrolada feita pelos garimpeiros e a modificação organizada da empresa de mineração são uma realidade que exigiu sérias medidas 


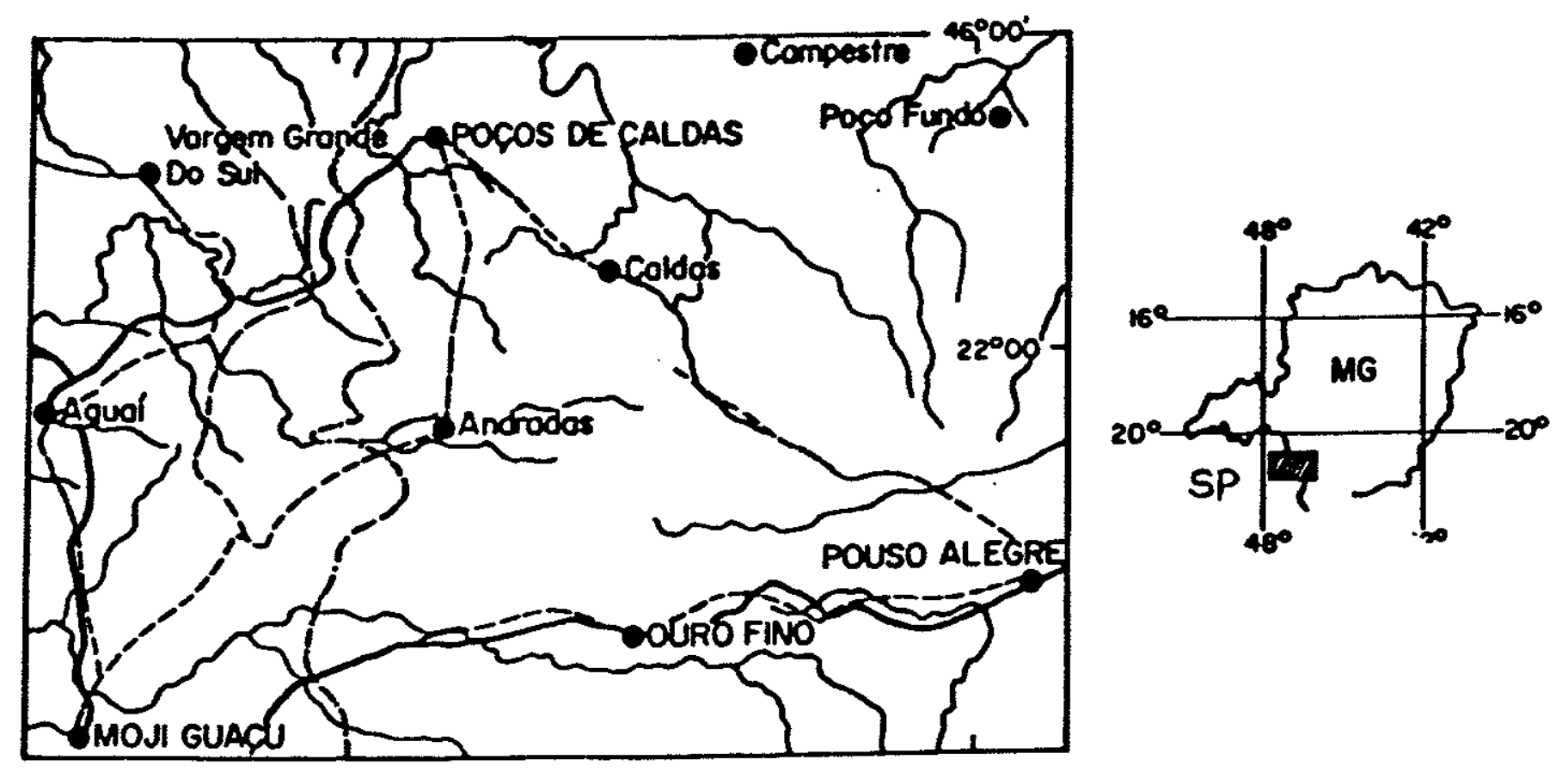

Flgura 1. Mapa do Locallzegäo do Maclgo Alcallno de Pogos de Caldas (ulbuich 1.983) 


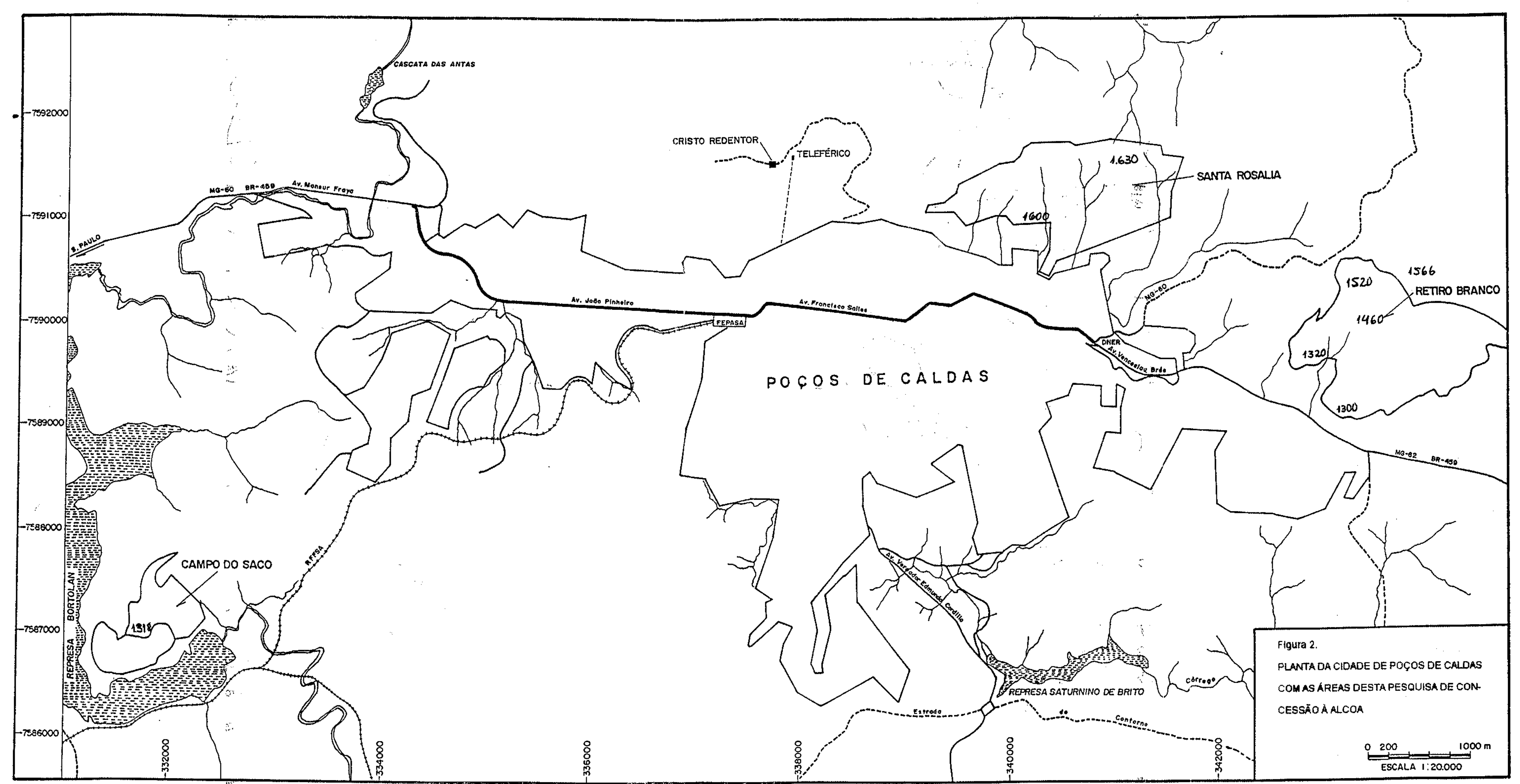


mitigadoras de impactos ambientais para que o desenvolvimento do Projeto Carajás não se visse prejudicado. Em vista destes problemas foi iniciada esta linha pesquisa que depois de 6 anos chegou ao primeiro resultado com a apresentação da Dissertação de Mestrado (Weissberg, 1989), que mostrou o potencial poluidor da mineração sobre os recursos hidricos através do ciclo das chuvas, que lavam e dissolvem os minérios e os rejeitos da mineração.

Desde o início, a pesquisa abordava o problema da reabilitação dos solos em caixas de empréstimo marginais a rodovia Serra dos Carajás - Marabá, dentro da área de responsabilidade da CVRD. As medições feitas revelaram que os nutrientes disponiveis nos solos de mata natural não se perdiam na reabilitação, ou seja os teores deles mantinham-se praticamente os mesmos. A continuidade da pesquisa só foi possível ocorrer em Poços de Caldas (M.G.), outra região do pais (figura 1), em busca de uma metodologia para preparo e revegetação das áreas mineradas.

As atuais leis ambientais no Brasil exigem a recuperação das áreas degradadas pela mineração e para os projetos em planejamento, exigem planos de recuperação, que devem apresentar projeto para reabilitar as áreas modificadas. Por isso várias tentativas têm sido feitas pelas empresas de mineração para que seja viável a exploração das jazidas e o posterior uso das áreas mineradas. Os sítios revegetados em Poços de Caldas são exemplos destas tentativas um tanto bem sucedidas.

Inicialmente foram usados Eucaliptus e Pinus e também Bracaatinga (uma leguminosa de grande porte), como monoculturas, em algumas áreas. Mais recentemente, cumprindo exigências das entidades ecológicas e das próprias leis ambientais, estão sendo usadas várias espécies arbóreas e arbustivas, algumas exóticas, mas a maioria são mudas desenvolvidas em viveiro próprio da companhia, a partir de sementes colhidas nas matas dos arredores.

As seis áreas em reabilitação, escolhidas para esta pesquisa, estão distribuidas pelas encostas, no Campo do Retiro Branco, no Campo de Santa Rosália, estando uma delas em situação menos acidentada (Campo do Sacco), mais afastada da cidade (figura 2). As idades de preparo das áreas escolhidas variavam de 12 anos a recém reabilitadas, no inicio da pesquisa. 


\subsection{OBJETIVOS}

Esta pequisa teve como objetivo geral o estudo da reabilitação de solos na área minerada para bauxita em Poços de Caldas (MG) através de comparação entre características dos solos naturais e dos solos novos com várias idades de reabilitação, desde 0 até 12 anos (do início da pesquisa), preparados segundo diferentes procedimentos. Os solos acompanhados desde o inicio (três áreas) foram monitorados durante 4 anos com observações e análises sobre os materiais.

Este estudo comparativo levou em consideração características de ordem textural (granulometria), estrutural (macro e micromorfologia), mineralógica, físicoquimica ( $\mathrm{pH}$ e umidade residual) e química (comportamento do Al, Si e Fe, M.O. e C).

Como objetivo especifico, a pesquisa visou a definição dos procedimentos com maior sucesso na reabilitação das áreas, em termos de estruturação pedogenética dos materiais que passaram a funcionar como solos novos, e de desenvolvimento da vegetação plantada em relação a evolução dos teores de carbono orgânico e de matéria orgânica total nos solos.

\subsection{REVISÃO BIBLIOGRÁFICA}

Esta revisão bibliográfica é mais uma procura dos temas direta ou indiretamente relacionados à pesquisa desenvolvida. Isto se deve principalmente porque esta pesquisa trata de uma abordagem nova sobre a recuperação de áreas degradadas. Nela procura-se mostrar que para recuperar uma área é necessário promover a reabilitação dos solos, um processo pedobiogeoquímico que se desenvolve para suportar uma vegetação inicial e depois, a própria evolução ambiental se encarrega de adaptar a nova área ao contexto geral.

A preocupação com o desenvolvimento ecológica e economicamente sustentado, deve ser hoje parte das pesquisas que tratam de problemas ambientais. As atividades humanas para ocupação dos espaços e para exploração dos recursos naturais vêm, ao longo do tempo, modificando a paisagem com uma intensidade crescente, relativa ao aumento da população e a demanda cada vez maior dos produtos explorados. Se avaliados friamente os pontos de referência do nosso desenvolvimento recente, pode-se concluir que a instalação de indústrias de todos os portes, bem como o consumo cada vez maior das diferentes matérias primas, têm 
contribuido para que ocorram verdadeiros sacrifícios ambientais, em nome do desenvolvimento.

O nível de sofisticação que o Homem vem atingindo em bens manufaturados e a velocidade com que estes produtos se tornam obsoletos, vêm despertando o interesse do profissional que lida com as fontes destas matérias primas minerais, o Geólogo, e dos pesquisadores que têm estudado o ambiente para medir o limite de modificações suportáveis, ou seja, sua resiliência.

A divisão do mundo atual em países desenvolvidos e paises em desenvolvimento, abre uma questão muito séria no que diz respeito às modificações ambientais locais ou regionais, que podem contribuir para as modificações que, com o passar do tempo, podem prejudicar a saúde ambiental e consequentemente a saúde das populações atingidas. Uma breve revisão dos fatos pode mostrar que os países em desenvolvimento, por näo terem atingido um desenvolvimento tecnológico suficiente para produzirem bens altamente acabados, têm exportado as matérias primas de seu sub-solo, primeiro, como fonte de recursos financeiros (a exportação de minérios atinge até $80 \%$ do total da exportação de alguns países), e, segundo, para tentarem seu próprio desenvolvimento, tendo em vista seus problemas estruturais que os mantêm dependentes de outros paises. O Brasil é um país que explora muito dos seus recursos minerais, por isto não está muito longe desta realidade.

É importante, então, alertar para a seguinte realidade: a exportação de matérias primas para suprir o desenvolvimento de paises desenvolvidos, tem mantido o subdesenvolvimento ambiental, social, cientifico e tecnológico de muitos paises. Hoje é muito forte a pressão de muitos ramos da sociedade, no sentido de lutar por maior integração entre os dois grandes grupos de países, na busca de um equilibrio comercial e social, a partir de uma troca de informações técnico-científicas.

Hoje ainda predomina a idéia de que "quem investe dinheiro quer ter um retorno cada vez maior e quer administrar o que investe", o que significa uma perda de autonomia nos vários setores atingidos. Frente a este quadro aqui vão ser abordados vários autores que ajudaram a definir a mentalidade desta pesquisa.

A primeira referência é um trabalho de Odum (1969) onde suas primeiras palavras são: "Um entendimento da sucessão ecológica supre o embasamento para solucionar o conflito do Homem com a Natureza". O termo "sucessão ecológica" envolve o desenvolvimento da sociedade humana. O ecossistema ou o sistema 
ecológico é a união da organização biológica interagindo com o ambiente físico, onde os fluxos de energia direcionam a cadeia trófica e os ciclos dos nutrientes, dentro do sistema. A sucessão ecológica deve ser entendida com base em três parâmetros: 1 . 0 progresso ordenado do desenvolvimento da comunidade que deve ser planejado; 2 . a modificação do ambiente físico pela comunidade, que deve ser controlado considerando que o ambiente físico determina o modelo $e$ os limites do desenvolvimento; 3. a estabilidade do ecossistema considerando os limites disponíveis para se manter a qualidade de vida (interação Homem-Natureza), em relação ao substrato (solo água, ar e energia).

Este artigo alertou para a importância de um planejamento para nortear o desenvolvimento, a todos os niveis num pais, e deve ser pensado em base mais cientificas, conhecendo os limites das modificações que o ambiente pode suportar. Todos estes limites precisam ser conhecidos e portanto estudados. Hoje, quando se fala que a aptidão da região amazônica é para a floresta ou culturas perenes, significa que as experiências desenvolvidas, planejadas ou não, já esclareceram limites de modificações suportadas pelo ecossitema amazônico ou seja a floresta não pode ser removida.

Fyfe (1981) discute o "Global 2000 Report to the President" e apresenta um quadro bastante interessante sobre o consumo da matéria mineral e alerta para os novos elementos procurados para atender ao desenvolvimento tecnológico. Ele diz que "o consumo desenfreado de matéria mineral leva ao "stress" ambiental, que está se intensificando e irá determinar a qualidade de vida em nosso planeta. Será responsabilidade dos geoquímicos providenciarem dados básicos necessários para adequar o planejamento às solicitações, lembrando que o último objetivo da Geoquimica é entender a história detalhada dos elementos químicos e como eles tomam parte nos grandes processos terrestres".

O autor considera que os processos externos que envolvem a terra, oceanos, atmosfera, biomassa, sedimentos e rochas são óbvios. Se tratamos de ambientes, devemos ter em mente que os resultados das interações entre os processos externos produzem o equilíbrio dinâmico necessário para que cada um dos processos evolua, ao longo do tempo, e que cada parte envolvida nos processos também está em constante evolução como geoesferas, e deve-se considerar também as transformações introduzidas pelo Homem como a ação da Antroposfera. 
As questões abaixo levantadas é também a preocupação desta pesquisa: "A Floresta Amazônica existirá no próximo século?"; "O inferno verde vai se transformar em deserto vermelho?"

Os aspectos salientados no artigo servem sobremaneira para nos alertar para a importância da geoquímica, na tentativa de resolver os problemas ambientais, de origem natural ou artificial, com uma visão interativa do que pode acontecer entre as mais simples e as mais complexas transformações do planeta, que se interrelacionam, num contexto mais amplo ou mais restrito.

Prigogine (1978) fala com propriedade de como a segunda lei da termodinâmica serviu de base para várias teorias e para este texto que ele traduz como "Os aspectos macroscópicos e microscópicos da Segunda Lei da Termodinâmica".

A importância de se conhecer as bases teóricas que discutem a irreversibilidade dos processos, tem dois aspectos para o estudo do meio ambiente. $O$ aspecto microscópico, onde a dimensão não importa e sim a capacidade de se alternarem as reações químicas porque existe a sua energia própria para reagirem (energia livre de reação), e o aspecto macroscópico ou o das interações entre sistemas, ou "geoesferas", que acontecem num sentido de manter um equilibrio dinâmico. $\dot{E}$ este equilíbrio dinâmico que envolve várias escalas. Convém então comparar a escala microscópica das reações químicas com a escala macroscópica das interações entre sistemas. O termo estabilidade, neste contexto, diz respeito à manutenção dos sistemas, dentro das condições mínimas, para que o equilibrio se mantenha. Fora deste intervalo de condições mínimas ocorre o desequilibrio, que interrompe as reações e as interações. Aplicado ao meio ambiente este enunciado traduz o impacto ambiental como a interrupção dos processos de reações e de interações.

Os processos reversiveis são consideramos atuantes na dimensão microscópica, ou seja, aqueles que se processam através das reações químicas, podem ocorrer nos dois sentidos: substâncias reagindo e formando outras, e ocorrendo a precipitação de um dos produtos se estabelece o sentido da reação, independendo do tempo. Quando se modificam as condições de concentração desta solução resultante o sentido da reação pode se inverter e passa a existir as substâncias inicialmente em solução. Os processos irreversíveis, que ocorrem na escala das interações (escala macroscópica), são responsáveis pelos equilibrios dinâmicos, onde os sistemas interativos têm sua própria independência e as energias internas de cada sistema são trocadas externamente através de pontes muito fracas, 
mas fortes o suficiente para manterem a interdependência entre os sistemas. O solo pode ser considerado um sistema-ponte ou um meio intersistêmico. Seria a interação entre: 1. evolução mineralógica ou as alteritas; 2. evolução da biomassa; 3. ação da água; 4. ação dos gases atmosféricos; e 5. ação da energia solar. O solo seria a interface destas interações.

Esta pesquisa buscou explicar o significado desta irreversibilidade, mostrando que o equilibrio dinâmico que existe nos solos pode ser "renovado" artificialmente. A natureza busca um novo equilibrio a partir do preparo artificial que promove o desenvolvimento rápido da vegetação, principalmente a semeada. Desta maneira o impacto é minimizado e as interações tendem a se restabalacer, numa nova condição, podendo evoluir e se aproximar muito da condição original, pois as condições externas do ambiente são mantidas (água, energia solar, gases e o substrato inorgânico).

Ricklefs (1987) trata do enriquecimento em espécies (diversidade) em associações locais de plantas e animais - comunidade biológica - onde ocorre os processos de formação de espécies novas e a sua dispersão (dispersão geográfica). Contra o enriquecimento em espécies estão os processos locais de predação, exclusão competitiva, adaptação e variação no estoque de espécies, que podem promover a extinção local de espécies. Durante as três décadas passadas os ecologistas têm procurado explicar a influência do ambiente físico sobre a diversificação das espécies, nas interações locais, interações que são geralmente devidas ao grande número de espécies coexistentes. Esta interdependência as vezes não acontece sob condições físicas similares e a diversidade local mostra uma dependência da diversidade regional. Estas observações sugerem que os processos regionais influenciam profundamente a estrutura da comunidade local.

A reabilitação dos solos pode ser comparada com a dependência de espécies em relação a um substrato, ao qual elas se adaptam, se fixam, se desenvolvem e passam a contribuir para a manutenção dele próprio de forma natural. Quanto maior o estágio de interação do solo com a biomassa, melhores condições ele pode oferecer às espécies para sua evolução.

A remoção da vegetação e do próprio solo reverte o processo a niveis bem rudimentares do sistema, mas a tentativa de reconduzir os processos, e a própria existência da comunidade regional (áreas naturais) pode acelerar os processos de retomada das espécies naturais. 
Groot (1987) fala da crescente preocupação dos governos com os problemas ambientais de degradação e poluição, apesar de não controlá-los. Algumas das principais razões do abuso sobre o ambiente são, a curto prazo, originadas a partir do processo de planejamento econômico, que ignora os efeitos a longo prazo, sobre o ambiente, e também o fato de que os critérios de estipular preços, principalmente concentrados em produtos e serviços, consideram os recursos naturais como sendo "produtos livres de taxação". Assim, do mesmo modo que se quantificam os bens produzidos e serviços, os custos ambientais também devem ser considerados e planejados nos procedimentos econômicos.

Desta maneira pode-se e deve-se pensar em termos de planejamento econômico considerando os gastos para preservação ou recomposição do ambiente, que sofre as açōes do uso dos recursos naturais. Deve-se ainda planejar recursos econômicos para o desenvolvimento de pesquisas que serão dirigidas a aperfeiçoar a minimização dos impactos ambientais.

Briassoulis (1989) apresenta alternativas para planejamento ambiental que visam adequar a teoria e a prática. Na ausência de um plano de ação, para se avaliar tendências, deve-se implementar o acompanhamento periódico dos aspectos em questão, o que significa monitorar os parâmetros alvos de modificações. Esta pesquisa usou esta técnica porque os efeitos poderiam ser estudados e comparados em diferentes estágios da reabilitação.

Johnson (1988) discute a possibilidade de monitorar variáveis que serviriam de indicadores do estado do ecossistema em estudo. Desta maneira seria possivel estabelecer um quadro diagnóstico da situação do sistema ou o seu estado de saúde. Neste trabalho foram escolhidos parâmetros físicos, físico-químicos e químicos que podem indicar a evolução dos processos associados a reabilitação dos solos.

Schaeffer et al (1988) fala dos dados que devem ser analisados e estudados para conheçer realmente o que se passa no meio em questão. Os dados devem, então fornecer informações concretas a respeito do ecossistema e quais as condições que mantêm seu equilibrio dinâmico. O estudo do solo, como sistema com vida própria, precisa ser estudado através de dados que caracterizam a sua função de suporte e nutrição da vegetação e da microfauna, e meio de percolação das águas. A importância de se restaurar a saúde do ambiente está no sucesso do trabalho de reabilitação do solo. Se a vegetação consegue se desenvolver, o sistema solo também 
evolui para um novo equilíbrio dinâmico e, ao longo do tempo a área se reintegra a paisagem.

Sedjo (1989) discute a problemática do $\mathrm{CO}_{2}$ como fator controlado na atmosfera pela existência das florestas. Medidas mostraram a eficiência das florestas para diminuir o teor de $\mathrm{CO}_{2}$ da atmosfera. Outro ponto importante é a retenção da umidade pelo ambiente em consequência da liberação lenta de vapor de água pelas plantas (transpiração).

Esta parte filosófica da bibliografia dá lugar agora a parte dos fundamentos teóricos dos estudos sobre os solos, indicando como estudar seus componentes orgânicos e inorgânicos, suas funções, suas propriedades e suas características intrínsecas, citando técnicas de estudos no campo e no laboratório.

Rai \& Kittric (1989) apresentam os principais minerais formadores dos solos, como produtos de alteração supérgena, que estabelecem um equilíbrio entre as condiçōes de umidade, matéria orgânica presente e atividade biológica, com o grau de estruturação do solo.

Oades (1989) trata da importância da matéria orgânica no desenvolvimento das pedofeições no material mineral, bem como das funções de adsorver cátions das argilas e dos materiais não argilosos de dimensōes das argilas, como o caso dos oxihidróxidos que os adquirem, em presença de baixos teores de matéria orgânica. Outras funções químicas da M.O. também são discutidas, pois apesar de ser um composto apolar, está relacionada com a formação de complexos organo-minerais cujas funções ainda estão sendo estudadas mais amplamente.

Alen et al (1989), Hsu (1989), Schwertmann (1989), Dixon (1989) e Drees et al (1989), em seus artigos apresentam as características dos minerais que ocorrem nos solos, sua origem e os processos formadores, bem como sua função no desenvolvimento dos solos. Ocorrência de minerais secundários, óxidos e hidróxidos de alumínio, óxidos de ferro, grupos de argilominerais, etc, são estudados como parte dos solos e como substâncias que participam nas reações físico-químicas que ocorrem dentro do sistema solo e que interagem na nutrição das plantas e animais.

Douglas et al (1982) trata de uma nova classificação dos solos, baseada no estudo micromorfológico aliado a outros estudos tradicionais. Este estudo é feito sobre amostras indeformadas de solo e compara as observaçōes de campo e de laboratório, 
utilizando equipamentos dos mais simples aos mais sofisticados. A utilização de amostras indeformadas é fundamental pois a arquitetura do solo é resultado dos vários processos biogeoquímicos, e sua dinâmica nas trocas solo-planta é caracterizada pelo tipo de microestruturação do solo".

Ruellan 1989, dá importância aos estudos dos solos utilizando-se as várias escalas (escala de campo, escala macroscópica das amostras indeformadas e a escala microscópica que relaciona as feições do solo com os componentes evolutivos ou seja as feições pedogenéticas) Ruellan, 1987; 1988 e 1991 deixa claro que o maior problema de degradação do solo é a perda das estruturas formadas por processos biogeoquímicos decorrentes das condições de superficie e fatalmente modificadas e degeneradas por manejo inadequado ou por várias atividades que mudam radicaimente a paisagem.

A evolução das estruturas do solo é o resultado da interação de vários processos que incluem a água (advindas dos vários compartimentos), a composição mineralógica primária e secundária dos materiais de superfície, a estrutura inicial e a estrutura da rocha-mãe e a atividade dos organismos e da matéria orgânica em sua contínua transformação sobre a superfície dos terrenos.

Reichardt (1985) apresenta um estudo da dinâmica do solo como um sistema semi-fechado que interage com as plantas e com a atmosfera (gases e água). Desta maneira fica claro que o funcionamento do sistema solo obedece às leis físicas. $O$ sistema solo então merece uma definição que inclui certas características de desenvolvimento, como formação de micro e macroagregados, micro e macrovazios (porosidade bem desenvolvida), atividade biológica intensa, existência de chuvas bem distribuidas ou irrigação, etc. Estes solos devem ser bem analisados nos seus aspectos gerais para fins de aproveitamento agrícola ou manutenção de cobertura vegetal perene.

Mermut (1992) apresenta o solo como um meio intersistêmico onde a mineralogia, a textura e o conteúdo de matéria orgânica são os principais responsáveis pelas interações com o clima e com a biota para desenvolvimento de uma dinâmica físico-química, na escala dos colóides. A importância dos estudos deste autor é mostrar que as reações a niveis tão minúsculos (escala uitramicroscópica) é o ponto-chave das interações orgânicas e inorgânicas que desenvolvem as microestruturas, os microagregados e as microfeições ligadas às funções dos solos. As análises de imagens de amostras indeformadas de solos mostram os fenômenos 
através das pedofeições, da distribuição e quantidade de matéria orgânica e das dimensões e composição mineralógica dos grãos e a função de suas cargas elétricas distribuídas à superficie para manter os pedoprocessos.

Tardy \& Roquin (1991) apresentam um aspecto muito importante da evolução dos materiais de superficie, desenvolvendo carapaças ferralíticas em ambientes tropicais, causando a destruição das estruturas do solo, porque as soluções de subsuperfície sobem e se precipitam sobre os terrenos por processos de oxidação, formando couraças duras e impermeáveis, descaracterizando o solo pré-existente. Este trabalho contribuiu para o entendimento da origem dos nódulos ou pedaços de couraça, encontradas em abundância, fazendo parte dos solos da região em estudo, cuja composição mineralógica apresentada pelo trabalho dos autores acima é: silica $5 \%$, caulinita $30 \%$, goethita $35 \%$ e hematita $30 \%$. Estes couraças são litodependentes e portanto autóctones, mas ao longo do tempo vários processos de alteração superficial transformam grande parte delas em pequenos blocos e seixos, grãos de areia, até siltes e argila, quando então passa a fazer parte do solo.

Outro aspecto importante apontado neste artigo mostra que o lençol freático, nas suas oscilações de nivel, interfere no avanço das acumulações de ferro e alumínio na superfície do solo e nas frentes de alteração dos materiais, além de estar relacionado com os fenômenos de hidratação e dehidratação dos minerais secundários. Um exemplo que interessa a este estudo é a transformação gibbsitacaolinita-gibbsita nos latossolos. Nesta discussão a atividade da silica e a atividade da água são importantes na definição do equilibrio acima descrito. Os autores demonstram que a atividade da água nos solos é controlada pela capilaridade. Quanto menor o raio do poro onde a água penetra, menor a sua atividade. A atividade da água é também igual a $p / p_{0}$ (razão entre a pressão parcial da água em ar seco $p$ e em ar saturado $p_{o}$ ). Como conclusõe importantes este trabalho afirma que o $\mathrm{pH}$ do solo e o teor de M.O. são fatores típicos de cinética dos processos do solo, enquanto temperatura e atividade da água são fatores termodinâmicos. além disso a atividade da água pode ser controlada pela pluviosidade, pelo tamanho dos poros e pela profundidade do nivel da água subterrânea.

Foi consultada também bibliografia para embasar o estudo micromorfológico do solo, uma ferramenta de estudo relativamente nova, porque parte desta pesquisa pretende verificar as diferenças entre os solos naturais e os materiais reabilitados (solos novos) a nivel das feições micromorfológicas. 
Bullock et al (1985) prepararam o "Handbook for soil thin section description", que se presta a ajudar no estudo de lâminas delgadas dos vários tipos de amostras indeformáveis de solo, observando e identificando as pedofeições e as estruturas próprias dos solos. Para complementar este estudo Selma S. Castro, (1989) organizou uma compilação de vários cursos e publicações, de vários autores, que se presta a ajudar no estudo de lâminas delgadas de amostras indeformadas de solos e foi consultado ao longo desta pesquisa.

A análise de imagens dos solos, estudo das pedofeições que são identificadas nas amostras indeformadas, utiliza equipamentos sofisticados para que sejam reproduzidas, analisadas quimicamente e quantificadas na escala em questão.

Protz et al (1992) utilizando imagens digitais de seçōes polidas de solos produzidas através de um Eikonix Scanner (4096 detectores em arranjo linear dos raios), faz um trabalho sobre a aplicação deste equipamento para análise espectral de imagem da micromorfologia do solo. O método de análise consiste em usar imagens separadas, coletadas em cada uma das ondas longas (vermelhas, verdes e azuis) da luz visivel (fonte incandescente) e nas ondas longas azuis por iluminação ultravioleta. Estes conjuntos de dados espectrais foram registrados, expostos e analisados como imagens de combinação de cores com um sistema de análise espectral de imagem (EASI/PACE). A identificação individual e delineação das feições pedológicas foram baseadas em suas morfologias e cores. A esta tarefa foi adicionada a capacidade de ampliação da imagem do sistema. Feições classificadas incluiam grãos de esqueleto, espaços vazios, manchas, matéria orgânica, concreçōes de manganês, carbonatos e zonas de esvaziamento. Um código interpretativo de cores para a apresentação das imagens das feições classificadas deste solo foi proposto e implementado. A porcentagem da área da imagem total ocupada por cada uma destas feições pedológicas foi derivada da classificação final da imagem.

Sweeney et al (1992) apresenta uma aplicação de análise espectral de imagem da micromorfologia, comparando dois solos: um nunca cultivado e outro cultivado por 30 anos com milho. Ele usou todos os equipamentos usados por Protz (1992) e concluiu que existe compactação no solo cultivado, com a redução da macroporosidade e dispersão de matéria orgânica e concentração ao longo de macroporos.

Chauvel et al (1991) estudando a porosidade de solos revegetados após o primeiro desmatamento, na Amazônia Central, verificaram que ocorrem mudanças 
muito acentuadas na distribuição relativa dos espaços porais do solo além de uma grande modificação a composição química dos latossolos da região. Para medida da porosidade foi utilizado um porozímetro de mercúrio.

Os trabalhos publicados sobre a área até o início da pesquisa são:

Dias (1980, 1981, 1982, 1983, 1984 e 1985) apresentou resultados dos trabalhos realizados na reabilitação das áreas mineradas pela ALCOA em Poços de Caldas, relativos aos métodos de preparo dos terrenos, usando vários implementos $e$ cita também os tipos de adubação, além das espécies de forrageiras e arbóreas utilizadas na revegetação das áreas. De maneira geral os materiais usados na reabilitação são os estéreis da lavra. Informações sobre o tipo de vegetação existente antes da lavra e a vegetação predominate na região encontra-se descrita nestes trabalhos. Dados climatológicos da região de estudo são os da estação meteorológica instalada no Campo do Retiro Branco, área bastante minerada no período de 19801990.

Williams (1986) apresenta um histórico das atividades de reabilitação de solos implementadas pela ALCOA durante os anos 80 e chama a atenção para a preocupação ambiental, que deve nortear estes trabalhos, procurando inovar com métodos cada vez mais adaptados e conhecer os melhores resultados para então estabelecer critérios para a recuperação de áreas mineradas. Este autor fala ainda das várias opções de novos usos das áreas, o que deve nortear o planejamento da reabilitação. Outro aspecto importante deste artigo foi avaliar o custo da reabilitação, concluindo que apenas 18 cents de dolar são gastos por tonelada de óxido de alumínio produzido. Desta maneira ficou demonstrado que a reabilitação é viável, de baixo custo e pode ser eficiente se levada a sério.

Weissberg 1989 apresentou os primeiros resultados da investigação sobre a reabilitação mal sucedida em caixas de empréstimo na Serra do Carajás. Este trabalho apresenta os resultados das análises de fertilidade que foram realizadas em vários perfis de solos de vegetação primária, de vegetação secundária, nas caixas de empréstimo e em áreas terraplenadas. Foi constatado que os nutrientes disponíveis nos solos de mata primária estavam presente nas demais áreas em teores muito próximos e pode-se concluir que o problema da reabilitação mal sucedida não se devia à falta de nutrientes nos solos. Por esta razão a pesquisa em questão não se preocupou com esta questão de fertilidade e sim com a estruturação dos solos. 
A revisão bibliográfica compõe uma abordagem ambiental que apresenta o ponto de vista e os resultados de pesquisas de vários autores que se procupam em sensibilizar a classe científica para um exame dos problemas decorrentes das mudanças sofridas pelos ecossistemas em função do desenvolvimento da sociedade e do consumo.

A bibliografia disponível não trata dos solos avaliando a evolução dos processos pedogeoquímicos atuantes. A reabilitação ainda é tida como um processo de revegetação e não como um processo artificial de desenvolvimento de um novo solo. Logo, os estudos desta pesquisa é um primeiro resultado que pretende apresentar a reabilitação dos solos como um assunto técnico-científico. 


\section{CAPITULO 2}

\section{APRESENTACÃO DA ÁREA DE ESTUDO}

As caracteristicas da área estudada serão apresentadas através da geologia, da geomorfologia, do estudo dos solos, dos recursos hídricos e das atividades da mineração. A geomorfologia da área inclui também dados sobre o clima e sobre a vegetação.

\subsection{GEOLOGIA}

O maciço alcalino de Poços de Caldas se apresenta sob forma de uma grande cratera vulcânica, que mede aproximadamente $30 \mathrm{Km}$ de diâmetro. As bordas da cratera estão a uma altitude média de $1.600 \mathrm{~m}$ e a parte central fica numa cota mais baixa $350 \mathrm{~m}$. A região em torno da cratera está a uma altitude de $600 \mathrm{~m}$ e é constituida de gnaisses e sedimentos recentes. Na periferia externa, os taludes são relativamente abruptos, enquanto o platô central apresenta uma topografia menos irregular, ressaltada pelas diferenças litológicas, principalmente a presença de corpos intrusivos de rochas intermediárias a básicas.

As rochas mais comuns são sienitos, que apresentam as texturas: fina (tinguaitos), média (fonolitos) e grosseira (foiaitos). Uma grande parte do maciço alcalino sofreu uma fenitização tardia e foi objeto de alteração hidrotermal intensa (metassomatismo potássico), responsável pelo aparecimento dos chibinitos e lujauritos, que ocorreram na última fase da formação do maciço (Boletim DNPM, 1978; Ulbrich et al 1979; Ulbrich \& Gomes 1981; Ulbrich 1981). O mapa geológico de Ellert et al. (1959) da figura 3 , mostra os tipos de rochas que deram origem aos materiais de alteração supérgena, inclusive às grandes ocorrências de bauxita.

Segundo Schorscher (1992) a introdução do complexo alcalino fenitizou duas principais áreas das rochas interiores do maciço e Ellert (1959) descreveu o matassomatismo como responsável pela redução no conteúdo de quartzo nas rochas
do complexo alcalino. 

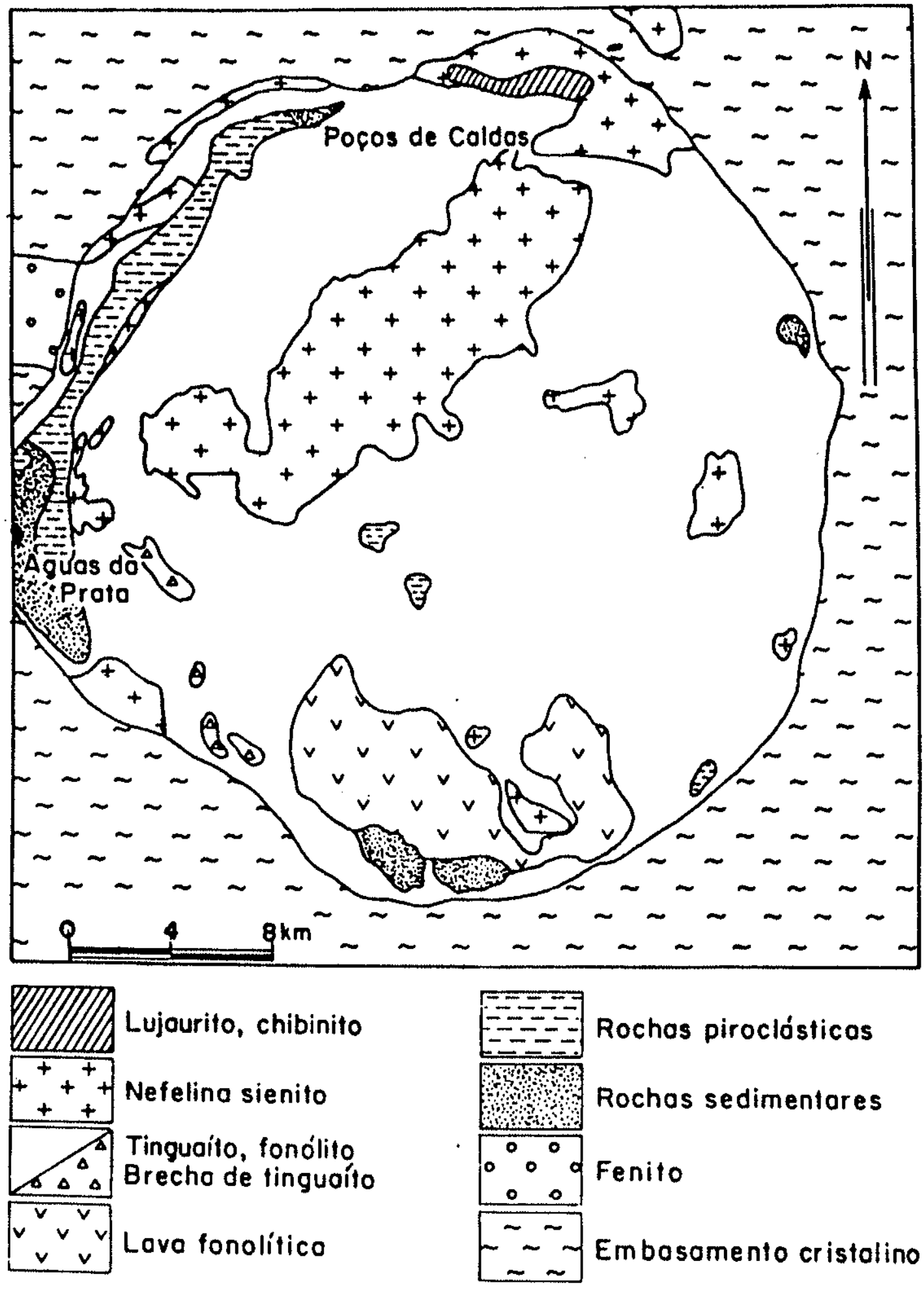

Figura 3. Mapa Geológico de Poços de Caldas e região (conforme mapa de Ellert, Coutinho e Bjornberg em Ellert, 1956. 
Segundo Ulbrich (1984) a alteração supérgena gerou um espesso manto de alteração, chegando a dezenas de metros, constituido basicamente de argilominerais tipo caulinita, oxihidróxidos de alumínio (gibbsita) e de ferro (goethita). Grandes volumes, no interior do manto de alteração sofreram uma lixiviação em sílica particularmente intensa, como parte do processo de hidrólise, formando os boisões de bauxita, onde a presença de caulinita é pequena. A caulinita ocorre principalmente no manto de alteração, fora dos bolsões bauxíticos.

Para esta pesquisa é importante saber que existia pouco quartzo presente nas rochas que sofreram uma grande lixiviação em sílica em geral, e que os processos superficiais, ajudados pelas fraturas abertas pelas reativações magmáticas, originaram as alteritas que incluem os bolsōes de bauxita e a partir destas alteritas os solos se desenvolveram através dos processos pedogenéticos adaptados às características climáticas da região.

A geologia de uma região é o estudo das rochas (mineralógia primária) e quase nada se fala sobre os processos que atuaram e deram origem aos materiais de alteração. Apesar disso é importante caracterizar o manto porque os materiais de alteração fazem parte das alteritas (materiais de alteração intempérica das rochas) e próximos da superficie sob ação de processos pedogenéticos formam os componentes inorgânicos dos solos. A figura 4 mostra o perfil esquemático que relaciona as rochas sãs e o manto de alteração autóctone, com os bolsões de bauxita. Também está apresentado o esquema do corte de lavra, cuja cubagem é feita a trado para delimitar os corpos bauxíticos e a área a ser atingida pela mineração.

\subsection{GEOMORFOLOGIA, CLIMA E VEGETAÇÃO}

O relevo muito acidentado do interior da cratera vulcânica se deve principalmente as várias remobilizaçōes magmáticas que intrundiram vários corpos de diferentes dimensões e formas. Obviamente a crosta pré-existente sofreu um intenso fraturamento, bem como as rochas formadas a partir das intrusões, com as atividades magmáticas posteriores. Os processos de superficie moldaram o relevo e geraram as lateritas e os solos da região. A evolução das lateritas, através de lixiviação da sílica, gerou corpos bauxíticos residuais que se distribuem dentro do manto (figura 4) e o controle pode ter sido estrutural (Schorscher, 1992) que orientou a distribuição dos 


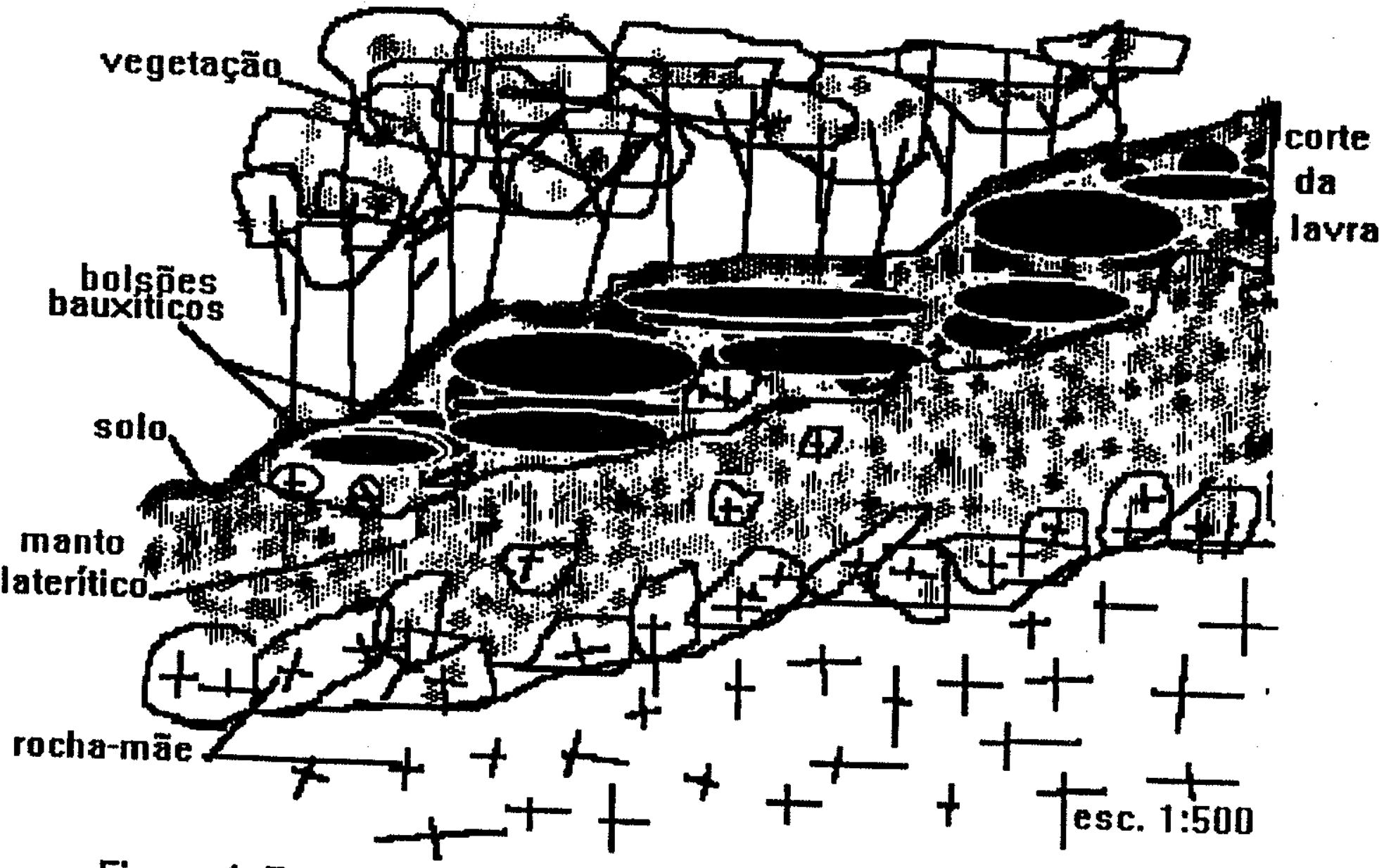

Figura 4. Perfil esquemático do manto apresentando os bolsões e
o corte de lavra 
fraturamentos que por sua vez facilitaram a hidrólise e o rápido escoamento das soluções.

Existe evidência de uma fase de desenvolvimento de couraças, que estão presentes em vastas áreas da região, sobre as quais se acumulam grandes volumes de água e onde se iniciou o desenvolvimento de solo nas linhas de fraturamento da couraça onde se desenvolve uma vegetação especial (campus rupestris).

Considerando que o relevo inicial foi controlado pela formação do maciço alcalino e outras várias intrusões, os recursos hidricos e o relevo evoluiram de modo interdependente pois as drenagens se encaixaram nas fraturas que sofreram alteraçäo mais cedo que a rocha menos fraturada. As drenagens de primeira a quarta ordem obedecem a um padrão que direciona todas elas para uma única bacia. Ao longo das drenagens estão concentradas a vegetação natural de floresta subtropical que são atualmente reservas ambientais pois são as çabeceiras dos mananciais da região do planalto de Poços de Caldas.

O clima atual da região é do tipo de clima de altitude (quente e úmido), com pluviometria média anual de $1.700 \mathrm{~mm}$. O período de chuvas mais intensas vai de outubro a abril e o período mais seco de junho a agosto (gráfico da figura 5). Os dados pluviométricos usados foram registrados na Estação Retiro Branco da ALCOA durante o período de 1985 a 1989.

Segundo Dias (1980) a temperatura média anual é de $17.7^{\circ} \mathrm{C}$, variando entre a máxima de $33^{\circ}$ e a minima de $-6^{\circ}$. As temperaturas mais elevadas ocorrem justamente no período de maior intensidade de chuvas (de novembro a março) e as temperaturas mais baixas durante o período mais seco (junho, juiho e agosto), quando podem ocorrer geadas.

A umidade relativa do ar (média anual) é de $78.2 \%$, variando entre o índice máximo de $83 \%$ e o minimo de $68.8 \%$. A evaporação média anual é de $808.1 \mathrm{~mm}$, sendo agosto o mes de maior evaporação - $93 \mathrm{~mm}$ (fim do período seco) e janeiro o período de menor evaporação $-57.3 \mathrm{~mm}$.

A vegetação natural é formada de matas subtropicais (subcaducifólias) com algumas espécies de zona temperada como Araucaria angustifolia. Predominam árvores de porte que não ultrapassa $20-25 \mathrm{~m}$ e alguns poucos individuos atingem 30 a $35 \mathrm{~m}$ (Dias, 1980). Ao longo do tempo esta vegetação foi sendo substituida por campos 


\section{PLUVIOMETRIA}

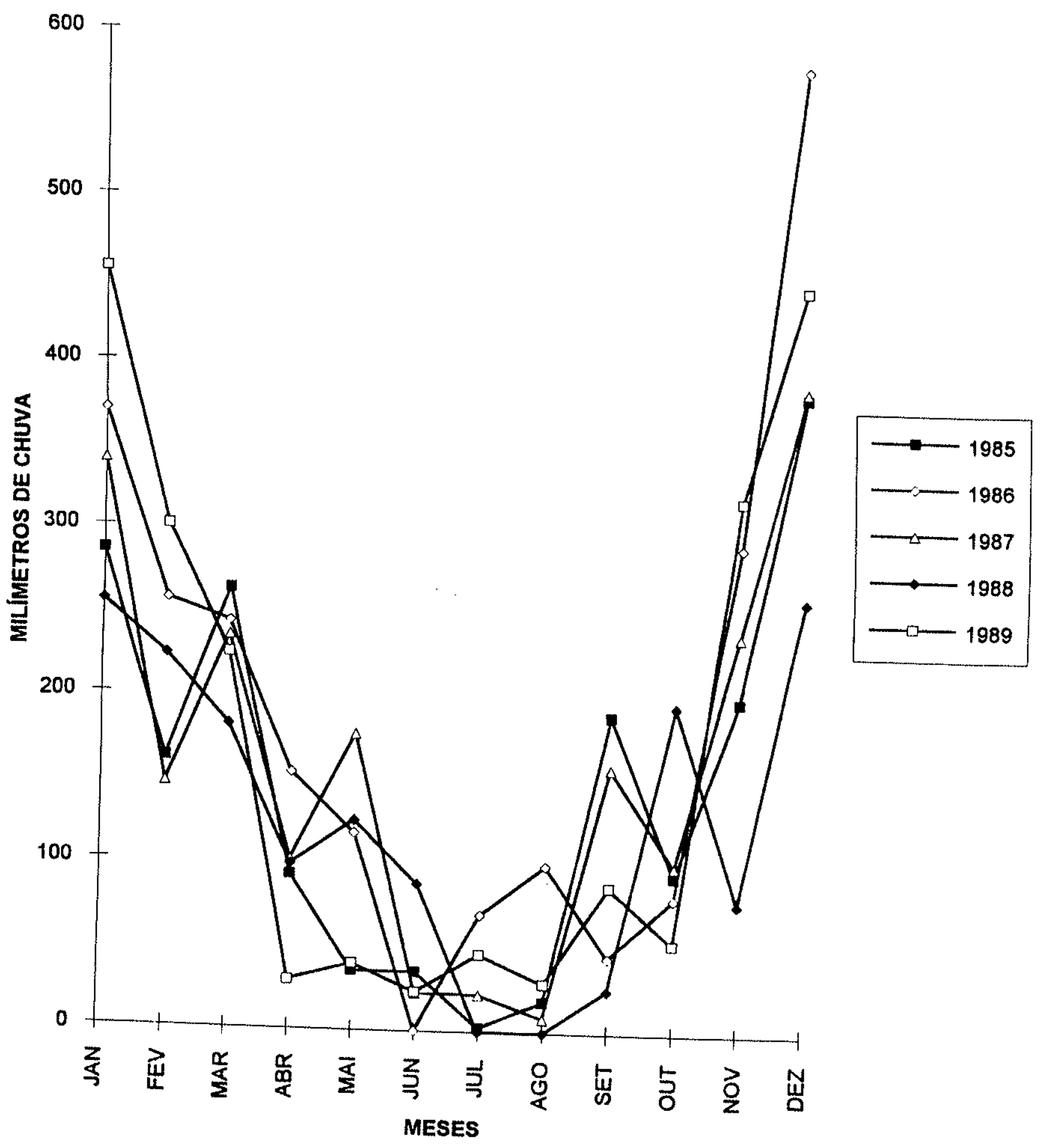

Figura 5. Gráfico da Pluviometria das áreas de estudo 
de cultivo que modificaram muito as características do solo com o uso de implementos agricolas e plantios alternados. Assim, com o empobrecimento dos solos apareceram vegetações diferentes como as de campos cerrados e as de campo de altitude. Os campos cerrados apresentam uma vegetação arbórea muito rala, de pequeno porte, muitas herbáceas e predominam as gramíneas de várias espécies e principalmente o capim cucuio nativo da regiāo.

\subsection{RECURSOS HIDRICOS}

A bacia que drena a região é a do Rio Pardo, que recebe afluentes ao longo de todo o planalto que contorna a depressão interna da cratera. Próximo a cidade de Poços de Caldas alguns ribeirões descem as encostas e seguem até os rios de porte médio, como o Rio das Antas, que desembocam no Rio Pardo. Ao longo das drenagens de terceira ordem desenvolvem-se matas ciliares no domínio dos campos cerrados. Estas matas se interdigitam em áreas mais baixas e juntam-se às matas com as características de floresta subtropical. Esta mata contribui definitivamente para a recarga natural dos recursos hídricos superficiais e subterrâneos, que abastecem a cidade de Poços de Caldas, e que mantêm os ecossistemas e as lavouras.

Apesar de localizada numa faixa sutropical, a região recebe uma contribuição pluviométrica anual bastante importante $(1.700 \mathrm{~mm})$, beln distribuida por todos os meses do ano (gráfico da figura 5).

As águas subterrâneas na regiäo foram importantes numa primeira fase da ocupação humana, por existirem fontes de águas termais com teores importantes de sais dissolvidos, o que propiciou o desenvolvimento turístico na regiäo. Com o início das atividades extrativas, principalmente da bauxita, e o aparecimento de outras indústrias a população cresceu e a água superficial se tornou escassa. Muitas empresas optaram pela perfuração de poços profundos para suprir o abastecimento.

Algumas depressões no substrato mais impermeável (carapaça ferralitica) formam lagos de diferentes dimensões, distribuidos pela região. Em outros pontos foram construidos açudes e barragens, que contêm grandes volumes de água. Estes lagos têm papel significativo no balanço hídrico da região porque a região tem característica de um ambiente relativamente isolado, dadas as condições topográficas da cratera vulcânica. Por esta razão os recursos hídricos precisam ser bem dimencionados e o seu uso bem planejado, uma vez que o balanço hídrico 
responsável pela sua manutenção depende muito da manutenção dos recursos ambientais da região (matas, topografia, solos, rios, lagos, riachos, etc.). Algumas das informações acima foram obtidas verbalmente, em visitas pela área e em relatórios da ALCOA (Dias, 1981).

\subsection{SOLOS}

Os solos das áreas estudadas são, principalmente, de dois tipos: latossolos amarelo-avermelhado, que se distribuem pelas áreas mais ingremes e os latossolos marrom-avermelhados, melhor estruturados, nas regiōes menos acidentadas e mais próximas das cotas mais baixas, onde a umidade e a matéria orgânica, que são transportada por gravidade, se encarregam de dotá-los de melhores condições de fertilidade. No geral são solos ácidos, mediana a fortemente insaturados $e$ predominam, em sua fração argilosa, caulinita, gibbsita e goethita.

Em vários cortes à margem das estradas foi possivel observar que a espessura do manto de alteração varia muito. Partes da floresta está sobre manto de espessura de poucos metros (drenagens). As áreas de meia encosta, entre as drenagens, apresentam espessura de vários metros $(10-15 \mathrm{~m})$ sob floresta e espessura de poucos metros ( 3 a $4 \mathrm{~m}$ ) sob a vegetação de campo cerrado. Estas diferenças estão relacionadas ao uso agrícola de várias décadas.

O uso dos solos para fins agricolas está relacionado principalmente ao cultivo do café, há muitos anos. Em áreas mais planas também existem os cultivos de batata inglesa e hortaliças e em altiplanos existem várias áreas de pastos. Está sendo introduzida na região a exploração de madeira, principalmente o eucaliptus e o pinus, que foram usados para revegetar áreas onde o empobrecimento dos solos não permitiu o desenvolvimento de outra cultura. Além disso alguns proprietários planejam o plantio de soja e algodão como opção para substituir o café. 


\subsection{A MINERAÇÃO}

Os bolsões de bauxita (figura 4) são concentrações de oxidróxidos de alumínio (gibbsita) que ocorrem em concentrações residuais. são extraídos do subsolo das elevações serranas ao redor da cidade de Poços de Caldas, que se situa nas cotas mais baixas $(1.250 \mathrm{~m})$ em relação às elevações $(1.600 \mathrm{~m})$ que compōem o relevo regional. Estes bolsões localizados através de sondagens a trados têm volumes variados e ocupam áreas importantes, da ordem de vários hectares..

A produção anual de bauxita da ALCOA era de 480.000 toneladas de bauxita seca em 1987. A concessão foi feita para exploração de 22 minas numa área total é de 356 hectares. O minério é rico com teores da ordem de $70 \%$ de alumina. 0 processamento da ALCOA inclui lavra, transformação em alumina e finalmente produção de alumínio em forma de cabos, lingotes, chapas e etc.

Antes da lavra é feito o desmatamento total da área e em seguida o decapeamento (retirada do solo). Esta camada que contém o solo orgânico tem espessura de $30-40 \mathrm{~cm}$, Dias (1984). A fase seguinte é a abertura das cavas para retirada dos bolsões. Após a retirada do minério a área apresenta um relevo bastante irregular e obviamente sem condições de qualquer uso posterior. A ALCOA tem adotado sérias medidas no sentido de revegetar as áreas mineradas, logo após as atividades da mineração e antes de iniciar a mineração já existe um planejamento para o uso futuro das áreas. Quando o proprietário da área prefere um reflorestamento para fins comerciais a empresa deixa a área reflorestada de acordo com 0 estabelecido. Em geral estes casos se aplica a áreas agrícolas que não têm condições de serem retomadas. Quando as áreas são de vegetação natural o órgão ambiental exige que se inicie a recomposição da paisagem.

O tipo de lavra à céu aberto é o método que se aplica neste caso, com abertura da cava removendo todo o material que existe sobre os bolsões bauxíticos. O material dos bolsões são retirados com máquinas por simples desmontes e carregamernto, porque o material é bastante terroso, de fácil extração. O método de extração abre cavidades de profundidade suficiente para que o volume máximo de minério seja extraído, permanecendo apenas os materiais cauliníticos com gibbsita disseminada, considerados estéreis. 


\section{CAPITULO 3}

\section{MATERIAIS E MÉTODOS}

\subsection{MATERIAIS ESTUDADOS}

Esta pesquisa estudou os solos desde os aspectos da paisagem (megaescala) até os estudos ao microscópio (microescala) numa sequência de métodos para conhecer as características em mega, macro e microescalas, de modo a entender o conjunto dos processos ambientais, os aspectos de influência da paisagem e as interferências que podem ser implementadas para promover a reabilitação das áreas mineradas

A paisagem natural da região de Poços de Caldas é formada por uma sequência de morros com cerca de $300 \mathrm{~m}$ de altura em relação às partes mais baixas do interior da cratera vulcânica. Esta paisagem é composta por tipos diferentes de vegetação que se sucederam, ao longo do tempo, tendo em vista o uso e ocupação dos solos. As florestas subtropicais cobrem vastas áreas das encostas, dos topos e das bases destas elevações. Em algumas áreas de topo dos morros ocorre vegetação de campo de altitude, uma vegetação composta por espécies de gramíneas e raras espécies de arbustivas. Em outras áreas de meia-encosta ou de baixada ocorre vegetação de campo cerrado, composta por várias espécies de gramineas e de arbustivas com alguns metros de altura e caule retorcido. Além destes tipos de vegetação são encontradas em áreas de couraça aluminoferruginosa uma vegetação de campus rupestris, que se desenvolve ao longo das linhas de fraturamento da couraça que acumulam materiais finos e umidade suficientes para germinar as sementes de espécies de baixo porte (gramineas e herbáceas).

As áreas mineradas estão distribuidas por toda paisagem e o tipo de lavra à céu aberto modifica o relevo localmente para retirada dos bolsões de bauxita, que fazem parte do manto de alteração das rochas alcalinas regionais.

As superfícies das áreas pós-mineradas, desmatadas e decapeadas, ficam sem solo e obviamente sem vegetação e com um relevo bastante irregular, onde permanecem os materiais bauxíticos de baixo teor, os materiais cauliniticos e os 
nódulos aluminoferruginosos de várias dimensões. A reabilitação das áreas pósmineradas feita pela ALCOA inicialmente era feita com preparo das superficies por terraceamento ou bancadas com o piantio de mudas de eucaliptus e pinus, obtendo um bom resultado do reflorestamento.

Nas áreas próximas às de florestas ou de vegetação típica regional este reflorestamento causava um impacto visual e também distorções ambientais na adaptação das espécies da fauna típica da região. Por esta razão o Orgão Ambiental local e o pessoal da ALCOA responsável pela reabilitação, iniciaram uma tentativa de restabelecer a vegetação natural, desenvolvendo mudas e plantio principalmente de espécies nativas. Mas esta nova diretriz para revegetação não levou a resultados satisfatórios, ocorrendo um desenvolvimento da vegetação num primeiro momento e depois de alguns meses a vegetação regredia, principalmente as forrageiras (gramineas) permitindo a ação das chuvas que provocaram intensa erosão dos materiais finos à superfície dos terrenos. Várias tentativas foram se sucedendo de maneira a encontrar um bom método de preparar dos terrenos e as melhores espécies vegetais que ajudariam no processo de reabilitação das áreas. Foi estabelecido que seria considerada reabilitada a área que desenvolvesse a vegetação plantada e semeada e que permitisse a retomada pelas espécies nativas.

Esta pesquisa acompanhou algumas etapas destas tentativas de reabilitar as áreas, preocupada mais em saber o que se passava com o material que recebeu a vegetação, tendo em vista a experiência anterior na Amazônia, onde tentativa igual näo foi bem sucedida (Weissberg 1989), o que não estava associada nem a vegetação escolhida, nem a falta de fertilidade dos solos. Além disso Ruelan (1988) deixa claro que as estruturas dos solos são responsáveis pelo desenvolvimento, fixação e nutrição das plantas, pois permitem a circulação de água, gases e das raizes e animais que interagem no desenvolvimento do solo e da vegetação. Acompanhando este raciocínio foram escolhidos aspectos observáveis ou mensuráveis que pudessem caracterizar os solos naturais e os solos novos e que avaliassem as diferenças responsáveis pelo desenvolvimento mal sucedido da reabilitação.

Os materiais analisados para caracterização das áreas de estudo foram coletados de perfis considerados representativos das oito áreas sendo seis em áreas reabilitadas e dois em áreas de vegetação natural, um em floresta subtropical e outro em campo cerrado. As áreas pós-mineradas sofreram um preparo do substrato, transplante de material em superfície e depois receberam semeadura de forrageiras ou gramíneas e plantio de mudas de diferentes espécies desenvolvidas em viveiro. 
As áreas de vegetação natural escolhidas (solos naturais): Área 1, no Campo do Retiro Branco, com vegetação de campo cerrado e Área 3 , no Campo de Santa Rosália, com vegetação de floresta subtropical estão adjacentes às áreas mineradas e os perfis foram abertos em pontos onde a vegetação está intocada pelas atividades extrativas. Os perfis foram abertos atravessando os horizontes $O, A$ e $B$ até atingir o horizonte $\mathrm{C}$ e as amostras foram coletadas nos limites e no meio de cada um dos horizontes.

As áreas reabilitadas escolhidas (solos novos) estão localizadas à meia encosta das elevações que circundam a cidade de Poços de Caldas e tiveram dois principais métodos de preparo: terraceamento e suavizamento.

O terraceamento foi o método usado nas áres reabilitadas mais antigas (12 e 6 anos de reabilitação) e consiste em escavar degraus ou bancadas onde a superfície horizontal tem uma pequena inclinação para o contato com a superfície vertical e esta também tem uma boa inclinaçāo para diminuir a erosāo e manter a semeadura de espécies de gramíneas e de arbustivas.

O suavizamento passou a ser o método usado, substituindo o terraceamento, que não apresentou bons resultados para desenvolvimento das forrageiras, principalmente nos taludes das bancadas; além disso, este método reduziu gastos com construção de drenagens necessárias no caso do terraceamento. O suavizamento consiste em corrigir as irregularidade deixadas pela extração mineral, com máquinas niveladoras; as superfícies niveladas se interceptam em drenagens com inclinação igual à do suavizamento, de modo a conseguir um relevo o menos acidentado possivel, para reduzir ao máximo a erosão pelo escoamento superficial das chuvas, permitindo o desenvolvimento da semeadura e das mudas. Nas partes mais baixas das áreas foram abertas grandes valas para receberem os materiais carreados pela
erosão.

Tanto as áreas com terraceamento como as suavizadas receberam, sobre a superfície terraplenada, transplante de uma camada de cerca de $30 \mathrm{~cm}$ de material revolvido, retirado de barrancos escavados junto às bordas das áreas de vegetação natural, não mineradas, misturadas às alteritas e aos materiais dos horizontes $A$ e $B$. Após a distribuição destes materiais, as áreas receberam fertilizantes que foram dosados por método agronômico com base nas análises de fertilidade (tabela 1) feita com os materiais do solo decapeado ("top-soil" e parte do horizonte A) e da alterita. 


\begin{tabular}{|c|c|c|c|c|c|c|c|}
\hline \multirow[t]{2}{*}{ Material } & \multirow[t]{2}{*}{ M.O. (\%) } & \multirow[t]{2}{*}{$\mathrm{pH}$} & $\mathrm{Al}^{+++}$ & $\mathrm{Ca}^{++}$ & $\mathrm{Mg}^{++}$ & $\mathrm{K}^{+}$ & $\mathrm{P}^{+++++}$ \\
\hline & & & \multicolumn{3}{|c|}{ e.mg/100g } & \multicolumn{2}{|c|}{ microg $/ \mathrm{ml}$} \\
\hline Substrato & 0.3 & 5.4 & 0.0 & 0.2 & 0.1 & 4.0 & 1.5 \\
\hline $\begin{array}{l}\text { Solo } \\
\text { decapead } \\
\text { o } \\
(30 \mathrm{~cm})\end{array}$ & $\begin{array}{l}5.5 \\
a \\
6.7 \\
\end{array}$ & $\begin{array}{l}4.3 \\
a \\
5.0\end{array}$ & $\begin{array}{l}0.6 \\
a \\
1.1\end{array}$ & $\begin{array}{l}0.3 \\
a \\
0.6\end{array}$ & $\begin{array}{l}0.1 \\
a \\
0.2\end{array}$ & $\begin{array}{l}40 \\
a \\
56\end{array}$ & $\begin{array}{l}1.1 \\
a \\
2.0\end{array}$ \\
\hline
\end{tabular}

Tabela 1. Resultados das análises de fertilidade dos materiais usados no preparo das áreas

As áreas reabilitadas estudadas nesta pesquisa tiveram como critérios de escolha a idade da reabilitação, o tipo de preparo do terreno, os fertilizantes usados, os tipos de forrageiras semeadas e os tipos de vegetação plantadas (tabela 2). Os perfis representativos das áreas foram abertos até a profundidade de $50 \mathrm{~cm}$ tendo em vista que os materiais acamados à superficie e os materiais revolvidos para corrigir as irregularidade deixadas pela lavra atingiam esta profundidade.

Para verificar a homogeneidade dos materiais foram feitas em uma das áreas várias perfurações a trado manual coletando amostras a cada $10 \mathrm{~cm}$ comparando-as entre si. No laboratório após secagem e quarteamento das amostras foram feitas analises das classes granulométricas, da distribuição e tamanho dos nódulos em cada uma das profundidades. Esta foi uma fase preliminar da pesquisa para conhecer os métodos de preparo implementados.

A adubação típica para as áreas preparadas por terraceamento ou bancadas foi de dois tipos, uma para as superficies planas e outra para os taludes como mostra a tabela 3. A adubação típica para plantio das mudas desenvolvidas no viveiro para revegetação está na tabela 4 e a relação de espécies vegetais escolhidas para este fim, está na tabela 5 (Dias 1984). 


\begin{tabular}{|c|c|c|c|c|c|c|}
\hline Área & Idade & Tipo de preparo & Tipo de fertilizantes & Calcário & Tipo de forragem & Mudas \\
\hline 1 & natural & & & & & \\
\hline 2 - Campo do Retiro Branco I & 3 anos & terraceamento & adubação típica * & não & mistura típica ** & várias \\
\hline 3 & natural & & & & & \\
\hline $\begin{array}{l}4 \text { - Bracaatinga (Campo do Retiro } \\
\text { Branco) }\end{array}$ & 6 anos & terraceamento & adubação típica * & não & mistura típica ** & Bracaatinga \\
\hline 5- Campo do Sacco 1 & 7 meses & suavisamento & a.t.+YURIM+top-soil & $\operatorname{sim}$ & mistura típica * & várias \\
\hline 6 - Eucaliptus (Campo do Sacco) & 12 anos & terraceamento & adubação típica * & não & mistura típica * & Eucaliptus \\
\hline 7-Campo do Retiro Branco II & 7 meses & suavisamento & a.t.+YURIM+top-soil & $\operatorname{sim}$ & m.t. capim-gordura & várias \\
\hline \multirow[t]{5}{*}{8 - Campo de Santa Rosália } & início & suavisamento & a.t. + YURIM+top-soil & $\operatorname{sim}$ & 1. serapilheira & várias \\
\hline & & & & & 2.m.t. c/ c.gordura & várias \\
\hline & & & & & 3.m.t. s/ c. gordura & várias \\
\hline & a.t. - & adubação típica * & Tabela 3 & & & \\
\hline & m.t. - & mistura tipica ** & Tabela 4 & & & \\
\hline
\end{tabular}

Tabela 2 - Áreas de estudo 


\begin{tabular}{|l|c|}
\hline Fertilizantes & Kg/Hectare \\
\hline N-P-K $10-28-06 \mathrm{c} / 1 / 3$ de Hiperfosfato & $500-600$ \\
\hline Hiperfosfato de Cálcio & $200-300$ \\
\hline sementes & \\
\hline Capim gordura & 10 \\
\hline Capim chorão & 30 \\
\hline Bermuda grass & 10 \\
\hline Azeven anual & 3 \\
\hline Soja perene & 10 \\
\hline Dolichos lab-lab & 20 \\
\hline Leucaena lecocephala & 10 \\
\hline
\end{tabular}

Mistura típica para semeadura manual em áreas planas das bancadas

\begin{tabular}{|l|c|}
\hline Fertilizantes e outros & Kg/Hectare \\
\hline N-P-K 10-29-06 & $100-125$ \\
\hline Humus coloidal & $400-600$ \\
\hline Curasol & 22 litros \\
\hline Papelão picado & 20 \\
\hline sementes & \\
\hline Capim gordura & 3 \\
\hline Capim chorão & 10 \\
\hline Bermuda grass & 3 \\
\hline Carpet grass & 4 \\
\hline Azeven anual & 4 \\
\hline Soja perene & 1 \\
\hline Desmodium intortum & 7 \\
\hline
\end{tabular}

Mistura tipica para hidrossemeadura para taludes das bancadas

Tabela 3. Misturas tipicas para semeadura em áreas terraceadas (bancadas).

\begin{tabular}{|l|c|}
\hline Fertilizantes & Covas $0.60 \times 0.60 \times 0.60 \mathrm{~cm}$ \\
\hline N-P-K 10-28-06 & $330 \mathrm{~g}$ \\
\hline Hiperfosfato de Cálcio & $100 \mathrm{~g}$ \\
\hline Ácido Bórico & $4 \mathrm{~g}$ \\
\hline Sulfato de Zinco & $2 \mathrm{~g}$ \\
\hline Adubo Orgânico & 20 litros \\
\hline
\end{tabular}

Tabela 4. Adubação típica das covas que recebem mudas 


\begin{tabular}{|c|c|}
\hline Pitanga & Eugenia uniflora \\
\hline Jequitibá & Cariniana sp. \\
\hline lpế roxo & Tabebuia avellanedae \\
\hline Pau-marfim & Balfourodendron riedelianum \\
\hline Jenipapo & Genipa americana \\
\hline Guaiçara & Luetzelburgia pterocarpoides \\
\hline Ipê-mirim & Tecoma slans \\
\hline Esponja & Cassia famesiana \\
\hline Urucu & Bixa orellana \\
\hline Oiti & Moquilea tomentosa \\
\hline Guatambu & Aspidosperma ramiflorum \\
\hline Magnólia & Michelia champaca \\
\hline Aroeira & Astronium urundeuva \\
\hline Cabreúva & Myroxylon balsamum \\
\hline Guarantä & Esenbeckia leiocarpa \\
\hline Jatobá & Hymenoea stilbocarpa \\
\hline Pereira & Platycyamus regnelii \\
\hline Ingá & Inga sessilis \\
\hline Angico-vermelho & Piptadenia macrocarpa \\
\hline Jacarandá mimoso & Jacaranda mimosaefolia \\
\hline Amendoim & Pterogyne nitens \\
\hline Copaiba & Copaifera langsdorffii \\
\hline Ipê amarelo & Tabebuia vellosoi \\
\hline Sibipiruna & Caesalpinea peltoforoides \\
\hline Saguaragi & Columbrina rufareiss \\
\hline Tipuana & Tipuana tipu \\
\hline Cassia fistula & Canna fistula \\
\hline Cassia speciosa & Cassia speciosa \\
\hline Flanboyant & Delonix regia \\
\hline Cassia siamea & Cassia siamea \\
\hline Cassia aleluia & Cassia multijuga \\
\hline Jambolão & Eugenia jambolona \\
\hline Uvaia & Eugenia uvalha \\
\hline Pinha & Anona sp \\
\hline Cabeludinha & Colubrina rufa \\
\hline Mirindiba rosa & Lafoesia glyptocarpa \\
\hline Nogueira & Aleurites moluccana \\
\hline Guacá ou Canxim & Pachystroma ilicifolia \\
\hline Bracaatinga & Mimosa scabrella \\
\hline Unha de vaca & Bauhinia fissinerva \\
\hline Pinheiro do Paraná & Araucaria angustifolia \\
\hline Pinheiro bravo & Podocarpus lamberti \\
\hline Canafistula & Cassiafistula sp \\
\hline Canelinha & Ocoatea sp \\
\hline Grevilha & Grevilea robusta \\
\hline Black locust & Robinea Psedoaccacia \\
\hline Casuarina & Casuarina glauca \\
\hline
\end{tabular}

Tabela 5. Tabela das espécies vegetais que são usadas para revegetação das áreas reabilitadas

O uso da serapilheira, cuja importância foi ressaltada por Jacobs (1988) e Golley et al. (1978), entre outros, foi experimentado num pequeno espaço da Área 2 
com sucesso, e foi implementado em uma sub-área da Área 8, e pode ser considerado um procedimento de semeadura e adubagem natural pois este material contém as sementes das espécies naturais da floresta em estado de dormência (banco genético) e todos os nutrientes das partes das plantas caidas e em decomposição que servem de adubo orgânico .

O "top-soil" é a parte do solo que desenvolveu ao máximo a estruturação, sob ação dos processos pedogenéticos e recebeu a maior carga de matéria orgânica, ao longo do tempo (horizonte "O" ou solo orgânico 0-20 ou 0-30cm no perfil). Isto ocorreu com o acúmulo da serapilheira composta por dejetos animais, folhas, galhos, frutos $e$ sementes $e$, além da atividade da biota associada que desenvolvem agregados (associados às raizes) e túbulos (associados à atividade de vários animais) como descreve Zonn (1986). O uso do "top-soil" ajuda no início do processo de reabilitação porque contém muita matéria orgânica e muitos nutrientes prontos para serem assimilados pelas raizes. A empresa de mineração incluiu o planejamento da reabilitação no início da lavra, com a retirada do solo orgânico ou "top-soil" e empilhamento apropriado após o desmatamento das áreas a serem mineradas para uso após a lavra.

A distribuição do "top-soil" sobre as áreas (5, 7 e 8) onde foram adicionados os fertilizantes e o calcário, forma uma fina camada com espessura de mais ou menos $5 \mathrm{~cm}$, e depois é feita a ripagem ou subsolagem com um trator de esteiras B8-K que trabalha com "ripper" ou sulcador, penetrante até $1,75 \mathrm{~m}$ de profundidade. Esta subsolagem é feita paralelamente às curvas de nivel, o que permite uma boa entrada de água de chuva, evita a erosão excessiva e promove uma primeira estruturação dos materiais (Dias 1980,1981, 1982, 1983, 1984 e 1985).

Os fertilizantes tradicionais contendo nitrogênio, fósforo e potássio (NPK) são utilizados na proporção estabelecida pela adubação típica da tabela 4 e são distribuídos sobre as áreas preparadas. Estes nutrientes de origem química são assimilados rapidamente e são também carreados pelo escoamento superficial. Um fertilizante alternativo, o termofertilizante magnesiano YURIM, foi adicionado na adubação das áreas preparadas. Este termofertilizante é fabricado com minerais e rochas e contém silicatos, fosfatos além de magnésio, cálcio e ferro. O material final é o produto da fusão, à altas temperaturas destes materiais e posterior resfriamento brusco. Este vidro é moido e está pronto para ser usado. É pois um material granular vitreo que contém os nutrientes minerais, que, segundo informação do fabricante (Mitsiu do Brasil) são liberados lentamente em presença dos ácidos orgânicos 
existentes nos solos. A opção pelo uso deste fertilizante está relacionada com esta liberação lenta e o pó vítreo vai permanecer nas áreas por mais tempo.

A área que foi acompanhada desde o início do preparo (Área 8) recebeu o "topsoil" de modo planejado, ou seja, ele foi retirado antes da lavra e foi depositado em pequenas pilhas para diminuir a compactação que o material sofre quando depositado em grandes pilhas. Depois foi distribuído sobre a área já preparada com o calcário moído e os fertlizantes já acamados. Somente depois foi feita a ripagem ou subsolagem, mantendo o "top-soil" mais à superfície, sem muito revolvimento. Como esta área serviu de laboratório de campo para a pesquisa também foi feita a divisão em três sub-áreas adjacentes onde a revegetação obedeceu a três critérios diferentes: 1.mistura típica de forragem com capim-gordura, 2. mistura típica de forragem sem capim-gordura e 3. serapilheira. Entre as sub-áreas 1 e 2 foi deixada uma "áreapiloto" que não recebeu nenhum tipo de revegetação (nem forragem nem mudas). 


\subsection{MÉTODOS DE ESTUDO}

As caracteristicas dos solos naturais e novos foram estudadas com objetivo comparativo, para mostrar as diferenças mais importantes que podem ser associadas ao funcionamento dos solos. Como os solos novos têm diferentes idades de reabilitação também é possivel comparar a evolução destas características entre as áreas reabilitadas.

\section{Observações de campo}

As observações nos solos naturais foram feitas através dos perfis até o horizonte $\mathrm{C}$ e nos solos novos nos $50 \mathrm{~cm}$ iniciais, considerando que os perfis das áreas reabilitadas atingem esta profundidade em média e logo abaixo está o substrato pósminerado. As seguintes caracteristicas foram consideradas na observação dos solos naturais e novos:

SOLOS NATURAIS

TIPO DE VEGETAÇÃO

PROFUNDIDADE DO PERFIL

ESPESSURA DOS HORIZONTES

("O" até "C")

COR

ESTRUTURAS

TEXTURA APARENTE

RAIIZES

ATIVIDADE BIOLÓGICA
SOLOS NOVOS

TIPO DE PREPARO

IDADE

RESULTADO DA REABILITAÇÃO

(desenvolvimento da vegetação)

COR

ESTRUTURAS

TEXTURA APARENTE

RAIZES

ATIVIDADE BIOLÓGICA

A comparação das cores dos materiais terrosos e dos nódulos presentes foi feita através da escala de cores Munsell Color Chart.

As estruturas macroscópicas dos solos definem porçōes de materiais que ocorrem distribuidas nos perfis e podem ser individualizadas e descritas segundo a forma geométrica, a distribuição nos horizontes e o tamanho delas.

A textura aparente dos solos está relacionada às várias classes de grãos que os formam e foi estudada, no campo, pelo tato em porções umedecidas e pressionadas com os dedos. Os grãos de maiores (areias) se sobressaem em relação aos materiais 
mais finos (siltes e argilas) e podem dar uma idéia da quantidade de finos em relação aos materiais mais grossos.

O tipo e a quantidade das raizes ao longo dos perfis e a presença de animais como formigas, minhocas e cupins foram observações feitas porque a atividade deles ajuda no desenvolvimento das estruturasdos solos ( agregados e bioporos).

\section{Amostragem}

A amostragem dos solos naturais, nos perfis representativos, foi feita através de amostras deformadas de volume superior a 500 gramas, a cada dez centimetros até $50 \mathrm{~cm}$, e indeformadas orientadas de tamanho $8 \times 6 \times 2 \mathrm{~cm}$, coletadas em cada horizonte e nas transições, até o horizonte $\mathrm{C}$. Para os solos novos, a amostragem nas trincheiras abertas foi feita de dez em dez centímetros, até $50 \mathrm{~cm}$ de profundidade tanto para as amostras deformadas como para as amostras indeformadas orientadas.

As amostras deformadas ficaram 10 dias secando à sombra e foram quarteadas e separadas aliquotas para as diferentes análises. As amostras indeformadas foram levadas à estufa para secagem e depois foram impregnadas com resina plástica sob vácuo. Após impregnação as amostras indeformadas orientadas foram cortadas de modo que pudessem ser amostradas superficies horizontais e verticais. Feita a escolha das áreas para serem laminadas (áreas de $2 \times 4 \mathrm{~cm}$ ) também foram orientadas para se ter idéia das feições em três dimensões.

\section{Análises}

Usando amostras deformadas dos solos naturais foram feitas as seguintes medidas:

\section{a) Medidas de $\mathrm{pH}$}

As medidas de $\mathrm{pH}$ foi feita obedecendo ao método elaborado por Anderson et al (1983). É importante considerar que os ions $\mathrm{H}^{+}$disponiveis nos solos determina a sua capacidade de desestabilizar os minerais. Isto porque os ions que compõem os minerais são solubilizados em faixas de $\mathrm{pH}$ determinadas. Como exemplo os minerais que contém alumínio e ferro sofrem liberação destes elementos quimicos em $\mathrm{pH}$ abaixo de 4 e acima de 8 , logo um solo com pH abaixo de 4 desestabiliza estes
minerais. 
b) Análise granulométrica

A análise granulométrica foi feita com os grãos menores que $2 \mathrm{~mm}$ e os materiais acima desta fração foi separado para analisar as dimensões dos nódulos e a quantidade relativa deles. As classes de grãos escolhidas foram: argilas $(<0,002 \mathrm{~mm})$ e silte fino $(<0,005 \mathrm{~mm}$ e $>0,002 \mathrm{~mm})$ separadas por decantação cronometrada. Silte $(<$ $0,074 \mathrm{~mm}$ e $>0,005 \mathrm{~mm})$, areia muito fina $(<0,149 \mathrm{~mm}$ e $>0,0074)$, areia fina $(<$ $0,297 \mathrm{~mm} \mathrm{e}>0,149 \mathrm{~mm})$, areia média $(<0,59 \mathrm{~mm}$ e $>0,297 \mathrm{~mm})$, e areia grossa $(<2 \mathrm{~mm}$ e $>0,59 \mathrm{~mm})$, separadas por peneiramento. Conhecidas as porcentagens de cada classe granulométrica, elas foram plotadas em diagramas de textura do solo (figura $8 \mathrm{~A}$ ) e com a interpretação dos diagramas foi possível avaliar o efeito da textura na capacidade de retenção de água do solo, utilizando o gráfico da figura $8 \mathrm{~B}$, modificado do U.S.D.A. Forest Service, Handbook on Soil, 1981.

c) Análise de umidade residual

As medidas de umidade residual foram feitas durante as análises granulométricas com as amostras de TFSA. Aliquotas das amostras foram pesadas e levadas a estufa à temperatura de $50^{\circ} \mathrm{C}$ durante 48 horas e após este tempo foi pesada novamente. A diferença entre o peso inicial e o peso final determinou a umidade residual. Esta medida serviu para comparar cada material considerando a capacidade de perder água à temperatura de $50^{\circ} \mathrm{C}$ durante 48 horas.

d) Análise de carbono total

As medidas dos teores de carbono foram feitas pelo método da combustão via sêca usando o equipamento Carmograph 12A "wosthoff", método aperfeiçoado por Cerri et al, 1990. O carbono está presente nos solos como parte da matéria orgânica. A matéria orgânica é composta por três partes: humina, ácidos húmicos e ácidos fúlvicos Os ácidos húmicos contêm 55 a $60 \%$ de carbono orgânico, valor que determinou o coeficiente 1.7 que multiplicado pelo teor de carbono determina o teor de matéria orgânica no solo. Este coeficiente não é aceito totalmente porque a parte orgânica dos solos não se constitui exclusivamente de ácidos húmicos. A opção de determinar o carbono total simplifica estas controvérsias.

e) Análise da matéria orgânica

A importância da presença da matéria orgânica nos solos é muito grande tendo em vista que é um composto apolar que pode estar presente em dimensões de colóides, promovendo agregações organo-minerais ou microagregação nos solos. Além disso a matéria orgânica é responsável pela formação de quelatos que envolvem e sorvem nutrientes para as plantas. Waksman (1936) in Swain (1963) cita 
propriedades importante da matéria orgânica do solo. São elas: participa da cor dos solos, sofre coagulação por eletrólitos, absorve sais e gases, tem alta capacidade de retenção de água e associada às argilas fica protegida da decomposição. A medida da matéria orgânica total foi feita a partir da queima com água oxigenada, à quente, medida pela diferença de peso antes e depois da queima.

\section{f) Análise mineralógica}

O estudo da composição mineralógica dos solos foi feito por Difração de RaiosX, com equipamento Gerador Iris 6 e o Goniômetro URD 6, no Laboratório de Difração de Raios-X do Instituto de Geociências da USP utilizando o método do pó. A composição mineralógica é importante para antecipar o conhecimento dos materiais a serem estudados ao microscópio óptico, bem como para conhecer o tipo de argila e demais minerais presentes, o que ajuda a entender o estágio de evolução dos solos.

g) Análises micromorfológicas e microgeoquímicas

g.1. Estudo ao microscópio óptico

Os materiais, tanto das áreas naturais como das reabilitadas, foram estudados a partir de lâminas de amostras indeformadas orientadas e impregnadas. Estas lâminas orientadas horizontal e verticalmente foram estudadas sob microscópio óptico polarizante. Os estudos micromorfológicos objetivaram conhecer principalmente a estruturação dos materiais, ou seja a identificação dos microcomponentes sólidos, os poros e seu arranjo espacial e seu grau de desenvolvimento de acordo com manuais disponiveis (Bullock et al 1985; Castro 1989, e Mermut 1992). Algumas feições com aspectos importantes para o estudo micromorfológico foram fotografadas para ilustrar - estudo. Para observação de lâminas delgadas de amostras indeformadas de solos foi usado o Microscópio Petrográfico ZEISS do Departamento de Geologia Geral do Instituto de Geociências.

\section{Terminologia adotada na descrição das lâminas}

Componentes básicos do solo: materiais sólidos (minerais primários, secundários, substâncias amorfas e orgânicas).

Cristalárias: cutãs de neoformação com cristais bem desenvolvidos

Cutãs: revestimentos de superfícies em geral formados por iluviação ou neoformação.

Esqueleto: fragmentos de minerais primários que permanecem inertes ou parcialmente desestabilizados nos solos. 
Estrutura aglomeroplásmica: tipo de distribuição na qual o plasma dispõe-se esparsamente, ocupando de forma incompleta os espaços entre os grãos de esqueleto.

Estrutura de base: relação espacial entre os componentes básicos (esqueleto, plasma e vazios), o que estabelece um arranjo para classificar o solo.

Estrutura porfirosquélica: tipo de distribuição onde o plasma aparece como uma matriz densa na qual os grãos de esqueleto estão dispostos como fenocristais numa rocha porfiritica).

"Fabric": organização geral dos constituintes básicos do solo (trama, organização, fábrica)

Grau de pedalidade: grau de desenvolvimento da microestrutura dos solos, refletindo o avanço da pedogênese.

Neoformações: formações secundárias que ocorrem a partir da precipitação de ions em solução.

Pedofeições: feições geradas em função da pedoplasmação que promove dissolução, recristalização e remobilização de substâncias. Incluem os cutãs, os nódulos e etc.

Plasma: conjunto de produtos secundários gerados durante o intemperismo e pedogênese, que podem herdar um arranjo geométrico da rocha mãe (plasma primário) ou não (plasma secundário). Geralmente os grãos do plasma são muito finos. Neste trabalho, os minerais secundários muito bem desenvolvidos foram chamados de feições cristalinas, em oposição ao plasma fino, mais típico.

Pseudomorfoses: feições secundárias onde o plasma é primário, ou seja, mantem as feições geométricas do material anterior.

Vazios: constituintes do sistema poral.

A descrição micromorfológica das lâminas usa a terminologia acima e procura descrever os processo que thes deram origem com base na evolução dos processos pedogenéticos e nos tratamentos para a reabilitação das áreas.

\section{g.2. Estudo microgeoquímico à Microssonda Eletrônica}

Algumas lâminas foram separadas para estudo na microssonda eletrônica para estudo microgeoquímico dos constituintes básicos: os plasmas, as pedofeições e os revestimentos de poros, grãos e cavidades. Nos solos novos as modificações 
estruturais que ocorrem são devidas principalmente a deformações no sistema poral e revestimento por neoformação de cutãs e materiais amorfos. A Microssonda Eletrônica SX 50 CAMECA do Instituto de Geociências da Universidade Federal da Bahia foi usada para o estudo de lâminas selecionadas. As análises de Difração de Raio $X$ feitas com amostras deformadas serviram para indicar a composição mineralógica predominante dos solos naturais e novos. A partir delas foram analisados os componentes básicos das lâminas segundo a variação nos teores de $\mathrm{Al} 2 \mathrm{O} 3, \mathrm{Fe} 2 \mathrm{O} 3$ e $\mathrm{SiO}$. Foram obedecidas as seguintes condiçōes físicas para funcionamento do equipamento: $10 \mathrm{KV}$ de tensão, corrente de $10 \mathrm{nA}$ e o tempo de contagem inferior a 5 segundos.

\section{g.3. Estudo ao MEV}

Além dos estudos acima descritos foram observados ao MEV fragmento de um macroagregado de solos natural, retirado dos $5 \mathrm{~cm}$ iniciais do perfil na área de floresta ("top-soil") e fragmento de um bloco do substrato pós-minerado (alterita indeformada) da Área 8. O objetivo deste estudo foi conhecer a micromorfologia tridimensional dos agregados e do substrato bem como o hábito dos componentes básicos e sua composição química utilizando o EDS acoplado. Os fragmentos dos materiais indeformados foram estudados através do Microscópio Eletrônico de Varredura (M.E.V.) de marca JEOL 30A do Instituto Astronômico e Geofísico da Universidade de São Paulo. Os materiais de forma cristalina bem definida foram apontados e analisados pelo equipamento de energia dispersiva de varredura (E.D.S.) marca TRACOR que está acoplado ao M.E.V.

g.4. Análise de imagem de lâmina de solo

Parte de uma lâmina de solo natural foi usada para fazer uma análise de imagem com objetivo de medir a porosidade, ou seja a quantidade de vazios em relação a quantidade de constituintes sólidos. A análise de imagem de solo natural foi feita no equipamento SITIM-340 existente no Laboratório de Sensoreamento Remoto do Departamento de Geologia Econômica do Instituto de Geociências da USP, usando-se uma foto escanerizada de parte de uma lâmina de solo natural. Este equipamento está acoplado a um computador PC 486 DX2 com placa gráfica que trabalha com 32 bites e um monitor RGB de alta resolução. $O$ estudo da imagem foi feito por imageações coloridas através de canais diferentes, colorindo as feições pedológicas de modo a separá-las por cores. Para interpretação das imagens foi usado um programa de computador (software) que quantifica a área de cada cor aplicada às feições que se quer estudar (área de vazios em relação a área de componentes sólidos). Este tipo de análise de imagem pode auxiliar no estudo da 
porosidade dos solos ou da quantidade de vazios em relação aos componentes sólidos.

\subsection{EXPERIMENTO COM SOLO E BAUXITA}

Este experimento foi feito para verificar a solubilidade do alumínio sob ação direta da água sobre bauxita purificada e seca e sob camadas de solo natural dos $10 \mathrm{~cm}$ iniciais do perfil em área de floresta. Foi feito um estudo das caracteristicas físicas das águas antes e depois de percolar os meios preparados: solo, solo + bauxita e a bauxita pura.Os parâmetros físicos medidos foram temperatura, $\mathrm{pH}$, Eh e condutividade elétrica. Os teores de alumínio foram medidos antes e depois da percolação de cada meio estudado.

O equipamento reproduziu um gotejamento controlado sobre materiais levemente compactados dentro de buretas $(2,5 \mathrm{~cm} \phi \times 20 \mathrm{~cm}$ comprimento) com placas porosas de 40 a $60 \mu$ colada no fundo. A água deionizada, com pH 5.0 foi colocada em dois garrafões de 60 litros cada, interligados por um tubo de vidro $(1.0 \mathrm{~cm} \phi) \mathrm{com} 4$ saídas equidistantes, conectadas às buretas por mangueiras plásticas presas ao tubo de vidro acima e à rolha furada que tampa cada uma das buretas. O gotejamento foi controlado por pinças de Hofman de modo que o material permanecesse saturado de água mas a superfície livre. A água após percolar os materiais foi coletada em erlenmayers também tampados com rolhas furadas atravessadas pelos bicos de saída das buretas.

Em vista deste estudo foram separadas duas amostras deformadas da Área 8, uma da 2 a sub-área e outra da área-piloto e levadas para análise de $\mathrm{Al}^{+++} \mathrm{e} \mathrm{H}^{+}$. Os teores máximos aceitáveis para a planta (Moniz 1972) é $0.5 \mathrm{ppm}$. A partir deste limite o solo é considerado tóxico para a vegetação.

Segundo Galle (1986) existe uma grande preocupação em se definir a toxidez do alumínio para o ser humano. Em vista disso os resultados deste experimento perviram para mostrar outra grande importância da reabilitação, porque os materiais pós-minerados podem conter teores perigosos de metais ou compostos tóxicos que sob ação das chuvas podem ser dissolvidos (Mello 1990), levados para os recursos hídricos e consumidos pelas pessoas, causando problemas irreversiveis à saúde.

O experimento foi montado conforme mostra a figura $\mathbf{6}$ e as medições foram feitas duas vezes para verificar a sua reprodutibilidade e após esta verificação foram 




Figura 6. Esquema da equipamento para o experimenro com solo e bauxita: 1. solo, 2. bauxita, 3. 1/3 solo $+2 / 3$ bauxita, $4.1 / 2$ solo+1/2 bauxita. 
feitas medições em dois períodos de percolação pela água, um de 24 horas e outro de 7 dias.

Os quatro conjuntos de bureta-tubulação-erlenmayer foram montados contendo os seguintes materiais:

$\begin{array}{ll}1^{\circ} \text { conjunto } & \text { solo natural } \\ 2^{\circ} \text { conjunto } & \text { bauxita pura } \\ 3^{\circ} \text { conjunto } & 30 \% \text { solo sobre } 70 \% \text { de bauxita } \\ 4^{\circ} \text { conjunto } & 50 \% \text { solo sobre } 50 \% \text { de bauxita }\end{array}$

O objetivo deste experimento foi reproduzir as condições naturais e verificar como o solo pode atuar na percolação das águas de superficie admitindo que o solo reduz a reatividade da água (Tardy et al 1988). Desta maneira o solo pode evitar a solubilização de íns tóxicos dos minerais de minérios. Além desta hipótese está comprovado que a matéria orgânica dos solos formam complexos insolúveis com metais, tipo citratos, acetados e outras centenas de compostos porque ela é absorvida por eletrólitos (Waksman 1936 in Swain 1963). 


\section{CAPITULO 4}

\section{RESULTADOS OBTIDOS E DISCUSSÕES}

\subsection{ESTUDO DOS PERFIS}

\subsubsection{OS PERFIS DOS SOLOS NATURAIS}

\section{ÁREA 1 - VEGETAÇÃO DE CAMPO CERRADO}

O perfil representativo da Área 1 foi aberto em um barranco de $200 \mathrm{~m}$ de comprimento por $3,5 \mathrm{~m}$ de altura, próximo a área minerado do Campo do Retiro Branco I, com vegetação de campo cerrado (Foto 1). O perfil aberto pode ser visto na Foto $1 \mathrm{~A}$ e a profundidade, até o horizonte $\mathrm{C}$, é de $2,5 \mathrm{~m}$.

\section{Horizonte "O"}

Espessura - $20 \mathrm{~cm}$, com uma pequena camada de serapilheira $(5 \mathrm{~cm})$ Cor - 10YR $3 / 4$

Nódulos - $20 \%$ do volume do solo, tamanho centimétricos e milimétricos, cores $7,5 Y R$ $4 / 6$ e 7,5YR 7/8, predominantemente formado de pequenos nódulos cimentado por material argiloferruginoso

Textura - siltosa

Estruturas - agregados arredondados ligados às raizes $(1 \mathrm{~cm} \phi)$ com uma boa porosidade intersticial

Atividade biológica - intensa das raízes além da presença de biotúbulos mostrando atividade de formigas e minhocas.

Raízes - muitas finas e forma um tapete à superfície. 


\section{Horizonte A}

Espessura $-70 \mathrm{~cm}$

Cor $-7,5$ YR $7 / 8$

Nódulos - $20 \%$ do volume do solo, de dimensões centimétricas.

Textura - areno-siltosa

Estruturas - dois tipos: agregados arredondados $(1 \mathrm{~cm} \phi)$ e poliédrica decimétrica próxima ao contato com horizonte $\mathrm{B}$. Porosidade fissural e intersticial

Atividade biológica - pouca, principalmente das raizes

Raízes - ligadas aos agregados e nas paredes das estruturas poliédricas.

\section{Horizonte B}

Espessura - 80 a $150 \mathrm{~cm}$

Cor -7.5 YR $7 / 8$

Nódulos - poucos ( $5 \%$ do volume) e de maiores dimensões que no horizonte acima, cerca de 5 a $8 \mathrm{~cm}$ de diâmetro.

Textura - areno-siltosa

Estrutura - poliédrica lisa, maior que no horizonte A, com cerca de $30 \mathrm{~cm}$ de comprimento e largura variada, atingindo até $10 \mathrm{~cm}$, os poliedros são bem individualizados, com precipitação de manganes nas paredes por onde percolam as águas de chuvas e portanto as soluções descendentes. No interior destes poliedros aparecem nódulos de até $5 \mathrm{~cm}$ de diâmetro. Porosidade fissural bem desenvolvida. Atividade biológica - muito pouca principalmente das raízes que agem principalmente como alargadores dos espaços entre as estruturas poliédricas.

Raízes - de calibre mais grosso que as do horizonte $A$ e poucas.

\section{Horizonte C}

Espessura - a partir de $1,80 \mathrm{~m}$ até $2,5 \mathrm{~m}$ em contato brusco com a rocha muito Cor - 7,5YR 7/8 mais claro, os blocos de rocha têm uma auréola de alteração externa de espessura variada, e no interior a cor da rocha sã, cinza clara de textura afanitica. Textura - os materiais finos estão preenchendo espaços entre os blocos de rocha, como porções desmoronadas do horizonte acima. 
Estruturas - o aspecto geral deste horizonte é de blocos de rochas separadas por descontinuidade preenchidas por material incoerente de cor amarelo claro e granulação grosseira.

Atividade biológica - não aparece

Raízes - não aparecem

\section{ÁREA 3 - VEGETAÇÃO DE FLORESTA SUBTROPICAL}

O perfil representativo da Área 3 foi aberto num barranco da área de floresta subtropical próximo da área minerada do Campo de Santa Rosália. O procedimento para escolher este perfil foi a homogeneidade dos materiais ao longo do barranco de $200 \mathrm{~m}$ de comprimento por $15 \mathrm{~m}$ de profundidade aberto com os trabalhos de lavra. As fotos 3 e 3 A mostram respectivamente a vegetação tipica da floresta e o perfil aberto no solo natural desta floresta

\section{Horizonte "O"}

Espessura - $25 \mathrm{~cm}$. Um grande volume de serapilheira acima $(15 \mathrm{~cm}) \mathrm{com}$ três camadas muito nitidas apresentando os niveis de decomposição dos materiais. A camada de decomposição mais adiantada é formada por pequenas placas de material carbonoso que penetra na camada superficial do solo.

Cor - 5YR $3 / 4$

Nódulos - $20 \%$ do volume do solo, de dimensões centimétricas e milimétricas, de forma arredondada, de cores avermelhadas e amareladas destacadas no horizonte.

Textura - argilo-siltosa

Estrutura - grande quantidade de agregados arredondados de $1,5 \mathrm{~cm}$ envolvidos pelas raizes finas que penetram no solo a partir de um tapete à superfície. Porosidade
intersticial intensa. Atividade biológica - intensa com muitas construções dentro do horizonte, feitas por formigas e cupins. As raizes aparecem entre e intra-agregados.

Raizes - finas, formam um tapete de $5 \mathrm{~cm}$ de espessura e estão interligadas aos
agregados. 


\section{Horizonte A}

Espessura - 65 a $90 \mathrm{~cm}$

Cor - 7,5YR 4/6 mais para marrom

Nódulos - $20 \%$ do volume, de tamanho que varia de 2 a $3 \mathrm{~cm}$ de diâmetro

Textura - argilo-siltosa

Estrutura - agregados arredondados fartamente distribuídos por $25 \mathrm{~cm}$ de espessura, de 1 a $1,5 \mathrm{~cm}$ de diâmetro envolvidos e envolvendo as raizes absorventes. Porosidade intersticial boa. Abaixo dos agregados aparecem volumes sem limites muito nítidos, de aspecto terroso.

Atividade biológica - muito intensa com muitos formigueiros e as raizes formam uma trama muito forte, ajudando a manter a estruturação.

Raizes - finas fortemente entrelaçadas e ligadas aos agregados

\section{Horizonte B}

Espessura - 2,5 a $3 \mathrm{~m}$

Cor $-7,5$ YR $4 / 6$ mais avermelhada

Nódulos - mais raros $(10 \%)$ de diâmentro da ordem de 3 a $5 \mathrm{~cm}$ aumentando em profundidade. Junto ao contato com o horizonte $C$ aparecem nódulos que na realidade são blocos intemperizados da rocha com auréola de alteração. A superficie externa é identica à dos nódulos alumino e argiloferrufinosos.

Textura - argilo-areno-siltosa

Estruturas - volumes poliédricos bem definidos da ordem de $20 \mathrm{~cm}$ de comprimento com paredes impregnadas por dois materiais bem diferentes, preto (aderido) e branco (granular), possivelmente manganês (dendritos) o material preto e o material branco, caulim. As raízes penetram através destas superfícies. Porosidade por fissuras dos poliedros.

Atividade biológica - principalmente das raizes

Raizes - poucas e mais grossas que as superficiais, com as pontas protegidas por uma capa roliça.

\section{Horizonte C}

Profundidade - a partir dos $4 \mathrm{~m}$ e não existe contato brusco com a rocha fraturada. Os blocos alterados vão se intensificando até apareceram blocos maiores sem alteração.
Cor - 7,5YR 4/6 mais claro 
Nódulos - não aparecem, mas os seixos alterados da rocha alcalina estão distribuídos inicialmente mais raramente no contato com o horizonte $B$, e aumentam as dimensões e a quantidade com a profundidade, até que blocos de rocha predominem.

Textura - areno-silto-argiloso.

Estruturas - grandes poliedros com seixos no interior e depois dá lugar a muitos blocos com material intersticial distribuído entre eles.

Raízes - raras

Atividade biológica - não se observa

\subsubsection{OS PERFIS DOS SOLOS NOVOS}

Os solos novos tiveram dois tipos de preparo: terraceamento ou bancadas e suavisamento das superficies. A superficie inicialmente era um material terraplenado de origem laterítica (substrato pós-minerado), e acima foram distribuidos materiais dos horizontes $\mathrm{A}$ e $\mathrm{B}$ das áreas naturais adjacentes formando uma camada de $30 \mathrm{~cm}$ de espessura bastante compactada pelo trabalho das máquinas. Acima desta camada são colocados os fertilizantes misturados a algumas sementes de forrageiras, o corretivo calcário e, nas áreas mais novas, termofertilizante magnesiano e "top-soil" (últimos 6 anos). Depois é feita a sub-solagem ou "ripagem", que revolve todos os materiais e a espessura final da camada preparada fica entre $70 \mathrm{~cm}$ e $1 \mathrm{~m}$ de espessura. $O$ plantio das mudas é feito a seguir, manualmente e após sete meses do fim deste preparo foram iniciadas as observações e as coletas da amostras. As áreas mais novas foram monitoradas ao longo do tempo da pesquisa.

Além do teste inicial com abertura de furos a trado nas áreas reabilitadas mais antigas para verificação da homogeneidade dos materiais, foi feito o acompanhamento do preparo nas áreas mais novas. A partir destas informações um perfil aberto até o substrato pós-minerado em cada uma das áreas reabilitadas foi considerado representativo. Em geral esta profundidade atingiu $50 \mathrm{~cm}$.

ÁREA 2 - Campo do Retiro Branco I. Preparada por terraceamento ou bancadas.
Reabilitada há 3 anos no início da pesquisa

Reabilitada há 3 anos no início da pesquisa com mudas e forrageiras.

Vegetação anterior - campo cerrado

Posição na paisagem - meia encosta

Profundidade do perfil $-50 \mathrm{~cm}$ 


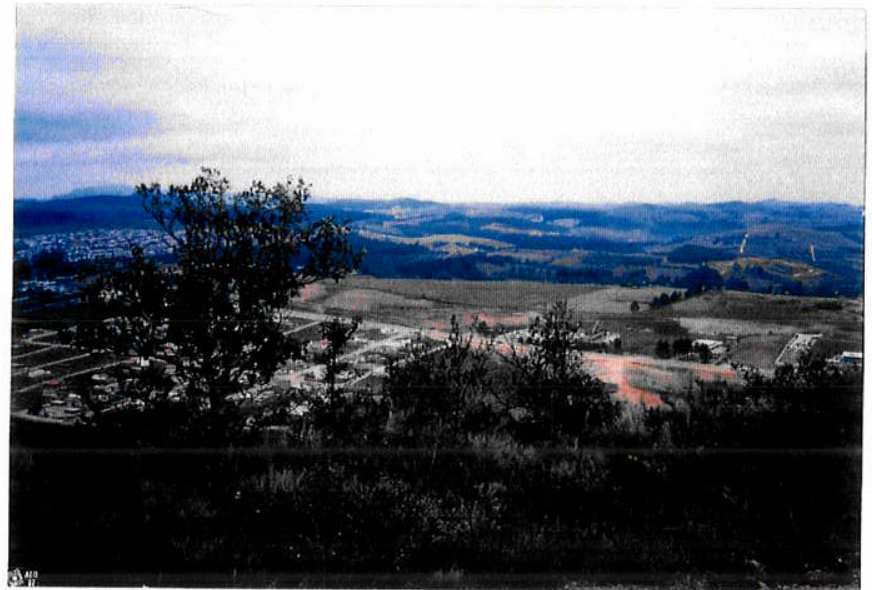

Foto 1 - Área 1 Vegetação de campo cerrado

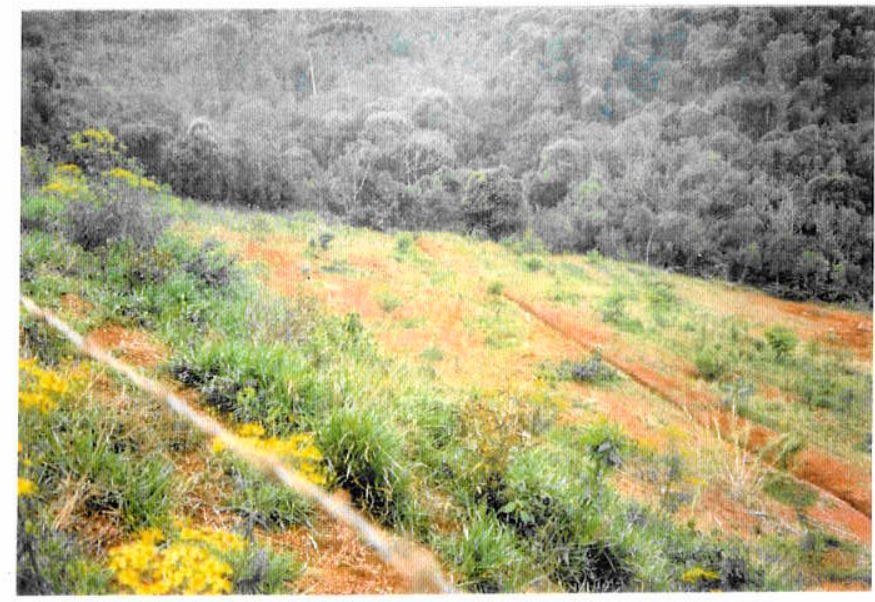

Foto 2 - Área 2 revegetada há 3 anos



Foto 1 A - Perfil aberto na Área 1

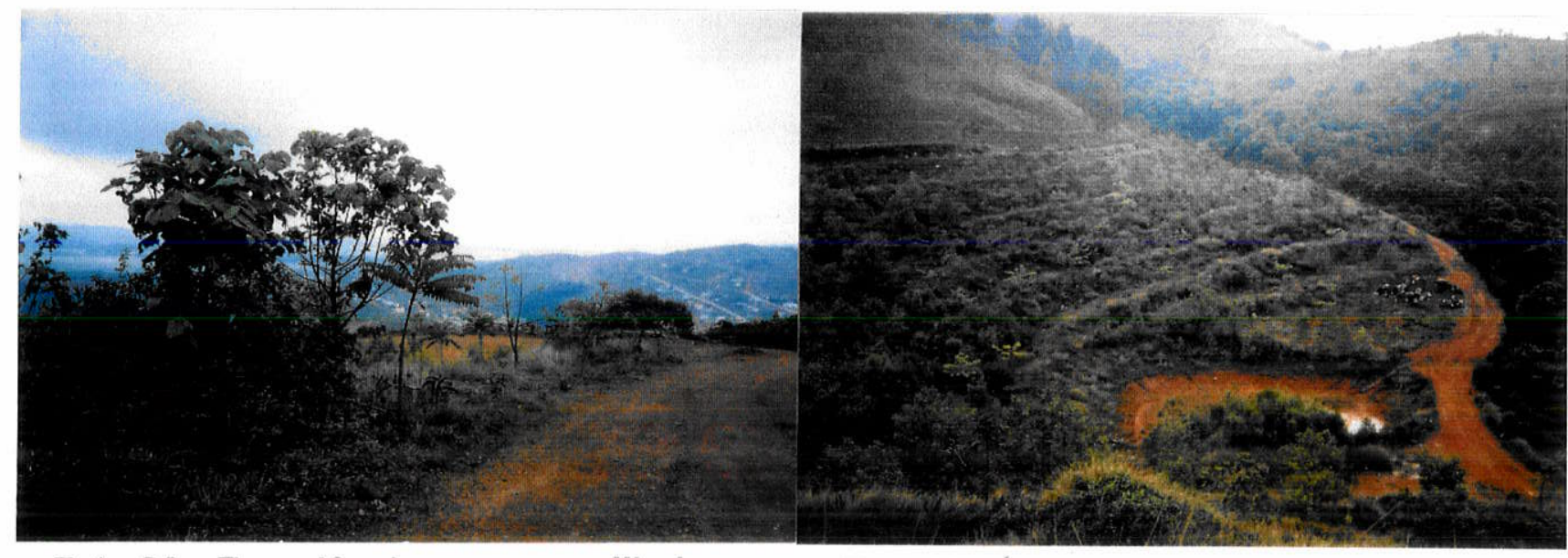

Foto 2A - Experiência com serapilheira

Foto 2B-Área $2 \mathrm{com}$ capim-gordura seco 
Acompanhamento - Duas visitas, uma no inicio da pesquisa ( 3 anos de reabilitada) e após 3 anos uma nova amostragem e observações.

Resultado da reabilitação - Na primeira visita a forragem semeada estava muito rala na superfície horizontal da bancada e quase nenhuma se desenvolveu no talude (foto 2). As mudas também tiveram pouco ou nenhum crescimento. Uma pequena parte da área foi usada para experimentar o uso de serapilheira e ocorreu o desenvolvimento de uma vegetação farta e diversificada (foto $2 A$ ). Uma tentativa de desenvolver capimgordura apresentou resultado positivo e a área ficou coberta por esta gramínea, mas no peíodo da seca este capim secou muito, com perigo de incendio (foto $2 \mathrm{~B}$ ).

Cor do material - 7,5YR 6/8 com porções intercaladas de cor 5YR 4/6 na primeira visita. Na segunda visita cor $5 Y R 3 / 4$ com nódulos intercalados de cor $5 Y R 8 / 3$ até $10 \mathrm{~cm}$ e entre $10-30 \mathrm{~cm}$ cor $7,5 \mathrm{YR} 4 / 4$. Material do substrato a partir de $30 \mathrm{~cm}$ cor $10 \mathrm{R}$ 4/4.

Nódulos - Na primeira visita existia grande quantidade mais à superfície, formando uma pavimentação $(60 \%$ do volume) consequência da erosão pelas chuvas, diminuindo a quantidade a partir de $6 \mathrm{~cm}$ profundidade ( $20 \%$ do volume). Na segunda visita as raizes do capim-gordura formou um tapete a superfície e os nódulos penetraram no material subjacente ( 40 a $50 \%$ do volume).

Textura - Na primeira visita, areno-siltosa com material intercalado mais escuro de textura argilo-siltosa até $30 \mathrm{~cm}$. Além desta profundidade aparece material compacto, argiloso, com fantasmas da rocha. $\mathrm{Na}$ segunda visita predomina a textura grumosa (areno-silto-argilosa) nos primeiros $30 \mathrm{~cm}$ e logo abaixo o substrato argiloso.

Estruturas - $\mathrm{Na}$ primeira visita estruturas poliédricas não bem definidas, e onde existe vegetação as raizes desenvolveram agregados arredondados até $10-15 \mathrm{~cm}$. Abaixo aparecem volumes poliédricos com paredes verticais lisas. Na segunda visita as raizes do capim gordura desenvolveram agregados arredondados entre $0-15 \mathrm{~cm}$ e abaixo aparecem os volumes poliédricos de parades lisas até $30 \mathrm{~cm}$.

Atividade biológica - Na primeira visita as formigas construíram formigueiros próximos às covas das mudas plantadas (material mais solto). Na segunda visita a atividade das raízes finas foi importante desenvolvendo agregados arredondados à superfície.

Raízes - Na primeira visita as raizes mais finas são poucas e estão mais à superficie e aparecem algumas de maior espessura, distribuidas ao longo do perfil aberto onde não ocorre vegetação à superficie. Na segunda visita as raízes estão distribuídas à superfície e associada aos agregados e penetram através das paredes dos poliedros. Ao atingirem o substrato $(30 \mathrm{~cm})$ elas desviam e formam uma trama horizontal. 
ÁREA 4 - Campo do Retiro Branco. Preparada por terraceamento ou bancada.

Reabilitada há 6 anos no início da pesquisa e revegetada com Bracaatinga.

Estudada em dois perfis, um no interior da área (perfil a), e outro na borda (perfil b).

Vegetação anterior - campo cerrado

Posição na paisagem - meia encosta

Profundidade dos perfis - $50 \mathrm{~cm}$ no interior da área (perfil a) e $70 \mathrm{~cm}$ na borda (perfil $\mathrm{b}$ ). Resultado da reabilitação - As mudas se desenvolveram favoravelmente alcançando 8 a $10 \mathrm{~m}$ de altura e diâmetro de $20 \mathrm{~cm}$ o tronco principal e vários outros mais finos em volta. A forragem semeada não teve bom desenvolvimento e apareceram musgos e líquens sobre a superfície já bastante erodida, onde ocorre uma pavimentação (foto 4). Em algumas partes da área foi semeado o capim-gordura com bom desenvolvimento mas no período de seca formou uma camada de ramos secos (foto $4 \mathrm{~A}$ )

Nódulos - grande quantidade de tamanhos pequenos $(0,5$ a $2 \mathrm{~cm}$ de diâmetros) à superficie formando pavimento, consequência da erosăo. No perfil a estes nódulos estão misturados a material mais fino de cor avermelhada (foto $4 A$ ) e no perfil b aparecem em pouca quantidade.

Cor - No perfil a (foto 4A) a cor predominante é $5 Y R \quad 3 / 4$ e no perfil $b$ a cor predominante é $7,5 \mathrm{YR}$ 6/8 (foto $4 \mathrm{~B}$ ) com manchas $5 \mathrm{YR} 4 / 6$ e outras 5YR $7 / 6$ intercaladas.

Textura - No perfil a a textura é siltosa até $30 \mathrm{~cm}$ e silto-argilosa até $70 \mathrm{~cm}$. No perfil $b$ entre 0 e $10 \mathrm{~cm}$ areno-siltosa, entre 10 e $20 \mathrm{~cm}$ silto-argilosa, entre 20 e $30 \mathrm{~cm}$ arenosiltosa (com mais areia que entre 0 e $10 \mathrm{~cm}$ ), entre 30 e $40 \mathrm{~cm}$ argilo-sitosa e entre 40 e $50 \mathrm{~cm}$ fortemente argilosa. Estas diferenças refletem possivelmente as características do substrato pois a erosão levou os materiais mais finos para o interior da área.

Estrutura - à superfície, onde não desenvolveu vegetação aparece uma estruturação tipo colunar pequena $(3 \mathrm{~cm})$ facilmente destacável em meio a grande quantidade de nódulos milimétricos e centimétricos. No perfil a, entre $0-5 \mathrm{~cm}$ a estrutura é de agregados milimétricos junto as raizes do capim-gordura e logo abaixo está formado um conglomerado de nódulos com material siltoso intersticial. No perfil $b$, à superfície, estão os pequenos poliedros colunares e abaixo aparecem volumes poliédricos mal delimitados cujas paredes são granulosas e parece acompanhar as linhas de fraturamento da rocha mãe. Faixas escuras cortam o perfil em direção não orientada (foto 4B). Boa porosidade intersticial.

Atividade biológica - aparecem formigas de várias espécies. As raizes absorventes formam uma fina camada à superfície misturadas aos agregados e penetram até cerca de $5 \mathrm{~cm}$. 


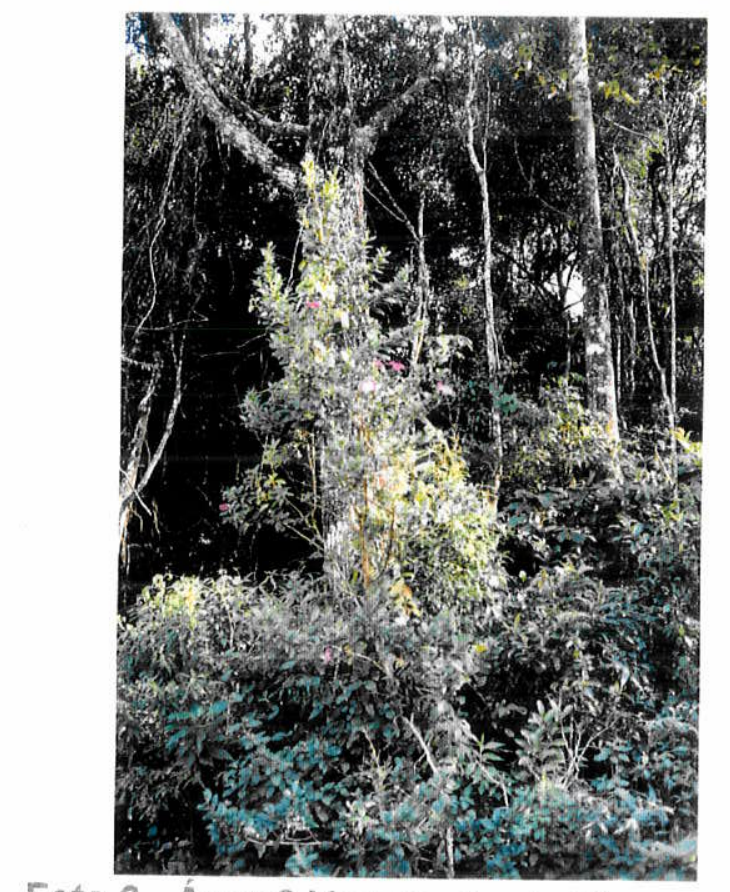

Foto 3 - Área 3 Vegetação de Floresta

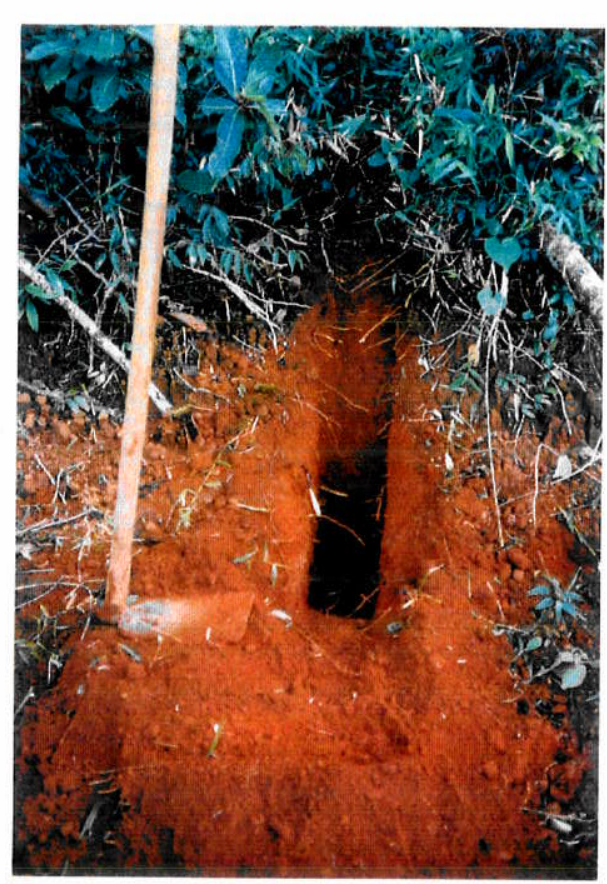

Foto 3A - Perfil aberto na Área 3

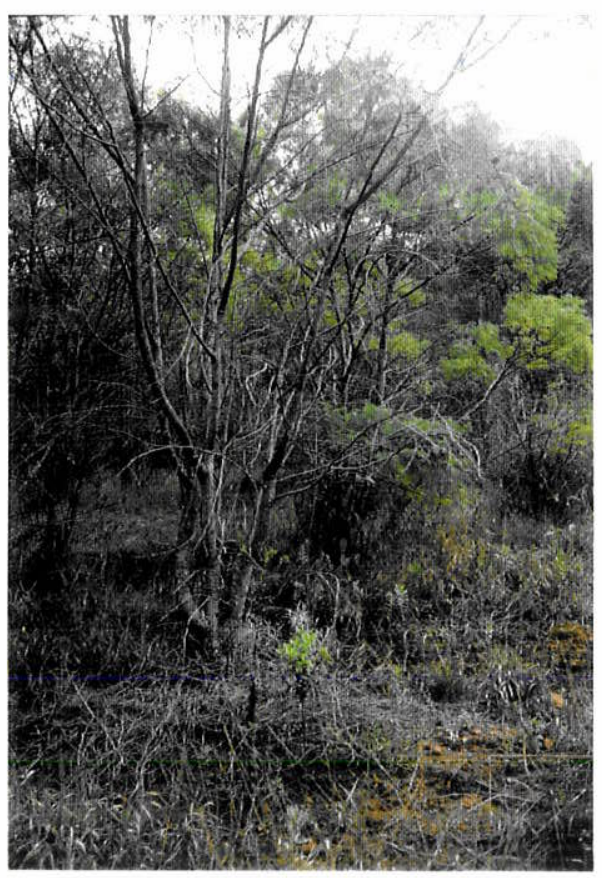

Foto 4 - Area 4 reabilitada há 6 anos com Bracaatinga

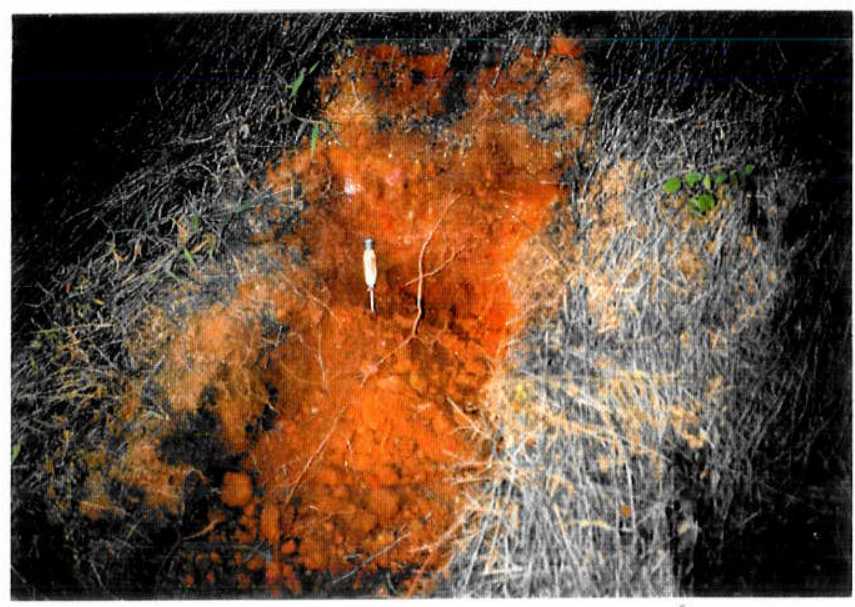

Foto 4A. Perfil no interior da Área 4

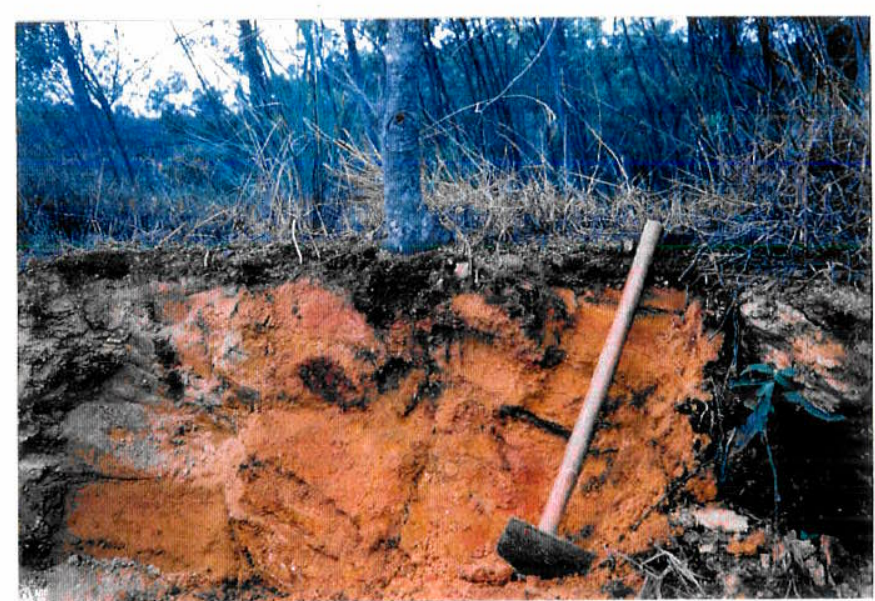

Foto 4B - Perfil na borda da Área 4 
Raizes - As raizes absorventes estão bem à superficie no interior da área, e nas bordas, elas estão num raio de $1 \mathrm{~m}$ das árvores e não chegam a formar agregados arredondados. Elas estão envolvidas entre as pequenas estruturas colunares desenvolvidas à superficie, associadas aos musgos e liquens.

ÁREA 5 - Campo do Sacco I. Preparada por suavisamento e revegetada com mudas e forrageiras (c/ capim-gordura) e posteriormente recebeu sementes de "Cassia speciosa".

Vegetação anterior - rasteira (predomina capim "cucuio" em tufos) sobre couraça Posição na paisagem - meia encosta em superfície pouco acidentada.

Profundidade dos perfis $-50 \mathrm{~cm}$

Acompanhamento - Tres visitas, uma após 7 meses, outra após 2 anos e outra após 3 anos de reabilitação com observações e coleta de amostras.

Resultado da reabilitação - depois de 7 meses apenas em torno das mudas plantadas as forrageiras se desenvolveram (foto 5) e a superfície restante permanecia descoberta permitindo a erosão pelas chuvas e dificultando ainda mais o avanço das forrageiras. Foi aberta uma trincheira que mostrava o subsolo dos materiais onde tinha vegetação e onde não tinha para observações, medidas e coleta de amostras. Outras tentativas foram feitas para desenvolver forrageiras nesta área e somente com outra semeadura de capim-gordura, após 2 anos, ocorreu um melhor desenvolvimento (foto $5 A$ ). Nesta visita foram abertos dois perfis, um onde não desenvolveu vegetação $e$ outro ao lado de uma muda circundada por capim-gordura. O capim-gordura secou, e outra tentativa foi feita com semeadura de leguminosa (Cassia speciosa) e capim napiê que atingiram um bom desenvolvimento em um ano (foto 5B) e possibilitou fixação de matéria orgânica e material mais fino à superficie, fatos observados em trincheira aberta entre superfície com vegetação e sem vegetação.

Cor - 5YR $4 / 4$ entre 2 e $30 \mathrm{~cm}$ e 7,5YR $3,5 / 4$ até $50 \mathrm{~cm}$ na primeira visita. Na segunda visita 2,5YR $3 / 4$ à superficie e entre 2 e $23 \mathrm{~cm}$ e $5 Y R$ 4/6 mais avermelhado no perfil sem vegetação. Na parte com vegetação cor $5 Y R \quad 4 / 5$ mais marrom entre 0 e $35 \mathrm{~cm}$ e $7,5 \mathrm{YR} 4 / 5$ até $50 \mathrm{~cm}$. Na terceira viagem as cores eram as mesmas nas partes com vegetação mas entre $0-5 \mathrm{~cm}$ os materiais apresentaram um tom mais marrom tingido pela matéria orgânica. Onde não tinha vegetação a cor entre $0-5 \mathrm{~cm}$ era $2,5 \mathrm{YR} 3 / 5 \mathrm{e}$ entre $10-30 \mathrm{~cm}$ era 5YR 4/4 misturada com 2,5YR 3/6, predominando esta última até $50 \mathrm{~cm}$.

Nódulos - Na primeira visita 30 a $40 \%$ do volume ao longo de todo o perfil e em superfície formavam pavimento, cor $5 Y R$ 4/6, tamanho variando entre 1 e $2 \mathrm{~cm}$ de diâmetro. Na segunda viagem o pavimento ocorria sobre a superfície onde não 
desenvolveu vegetação e onde a vegetação estava bem desenvolvida os nódulos (30 a $40 \%$ do volume) estavam distribuidos mais homogeneamente por todo o perfil. $\mathrm{Na}$ terceira visita o pavimento de nódulos estava restito a pequenas porções de superfície sem vegetação, e onde a vegetação se desenvolveu os nódulos estavam envolvidos por material mais fino e pelas raizes finas fazendo parte dos agregados.

Textura - $\mathrm{Na}$ primeira visita, próximo a superfície, entre $0-5 \mathrm{~cm}$ a textura era siltosa e em profundidade, até $50 \mathrm{~cm}$ argilosa intercalada por muitos nódulos. $\mathrm{Na}$ segunda visita a textura tinha mudado, mais areno-siltosa entre 2 e $10 \mathrm{~cm}$ e argilosa entre 10 a $50 \mathrm{~cm}$ nas partes sem vegetação e argilo-siltosa entre $0-10 \mathrm{~cm}$ e argilosa entre $10-50 \mathrm{~cm}$ nas partes vegetadas. $\mathrm{Na}$ terceira visita as partes sem vegetação apresentavam textura areno-siltosa até $20 \mathrm{~cm}$ de profundidade e abaixo silto-argilosa até $50 \mathrm{~cm}$. Nas partes com vegetação a textura era argilo-areno-siltosa entre $0-20 \mathrm{~cm}$ e argilosa entre 20 $50 \mathrm{~cm}$.

Estruturas - Na primeira visita o pavimento de nódulos predominava onde não havia vegetação e nas áres onde as forrageiras se desenvolveram apareceram agregados milimétricos arredondados associados às raizes finas, fixando o material mais fino e a matéria orgânica. Boa porosidade intersticial. Na segunda visita as estruturas se desenvolveram junto à vegetaçäo, associada às raízes. Alguma atividade de formigas foi observada com construção de formigueiros. Na terceira visita poucos espaços estavam sem vegetação com nódulos à superfície. Onde a vegetação estava bem desenvolvida ocorreu a agregação junto às raizes finas que envolviam nódulos e materiais finos. Em profundidade, entre 20 e $50 \mathrm{~cm}$, foi possivel observar que ao lado do sulco do preparo da área o material estava menos compactado individualizando volumes e longe dos sulcos o material estava mais compactado.

Atividade biológica - Nas proximidades da vegetação as raizes mais finas estavam associadas aos agregados milimétricos $e$ algumas espécies de formigas e
formigueiros.

Raizes - finas em superficie associadas ao capim-gordura e mais grossas em profundidade no perfil aberto onde não desenvolveu vegetação. Na terceira visita as raízes jà formavam tapete nas superfícies cobertas pela vegetação. 
ÁREA 6 - Campo do Sacco II. Preparada por terraceamento ou bancada e revegetada com Eucaliptus, com 12 anos no início da pesquisa

Vegetação anterior - típica de couraça (capim cucuio)

Posição na paisagem - meia encosta de região pouco inclinada

Profundidade do perfil $-58 \mathrm{~cm}$

Resultado da reabilitação - O reflorestamento com eucaliptus atingiu um bom desenvolvimento e não desenvolveu forrageiras no interior das árvores (foto 6).

Cor - 7,5YR $4 / 4$ entre 0 e $8 \mathrm{~cm}$ e abaixo muda para $4 / 6$, abaixo dos $40 \mathrm{~cm}$ aparece um material de cor $2,5 Y R 4 / 6$ muito avermelhado até $58 \mathrm{~cm}$.

Textura - argilo-siltosa proximo à superficie e varia muito pouco em profundidade para mais argilosa até $58 \mathrm{~cm}$. Nesta profundidade está o contato com o substrato argiloso compacto.

Estrutura - aparecem em superificie agregados milimétricos arredondados justapostos, associados às raizes finas, mas predomina o tipo de estrutura poliédrica forte com superfícies lisas percoladas por soluçōes que deixam marcas de sua passagem e por raízes mais grossas. Boa porosidade

Atividade biológica - muitos ninhos de minhocas em todo o perfil até $40 \mathrm{~cm}$, muitos fungos, tipo orelha-de-pau à superficie, muitas formigas e formigueiros, uma fina camada de serapilheira do próprio eucalipto e as raízes mais grossas penetram através das estruturas poliédricas

Raizes - muitas finas próximas à superfície e mais grossas ao longo do perfil.

\section{ÁREA 7 - Campo do Retiro Branco II. Preparado por suavizamento e revegetada com mudas e forrageiras. Acompanhado desde o início do preparo com coletas e medições a partir de 7 meses, com três visitas.}

Vegetação anterior - floresta subtropical

Posição na paisagem - meia encosta da região montanhosa (foto 7 )

Profundidade do perfil - na primeira visita 0,50m (foto 7A) e na terceira visita1,30m. $\mathrm{Na}$ segunda visita não foi aberto perfil. A área estava desenvolvendo as leguminosas (Cassia)

Resultado da reabilitação - desenvolvimento bom de forrageiras que, no período da estiagem, secou. Foi então feita a semeadura de leguminosa (Cassia speciosa) que em dois ano atingiu $6 \mathrm{~m}$ de altura (foto $7 \mathrm{~B}$ ) e desenvolveu horizonte "O" + A muito
nítido (foto $7 \mathrm{C}$ ). 




Foto 5 - Área 5 reabilitada há 7 meses

Foto $5 \mathrm{~A}$ - Área 6 reabilitada há 2 anos

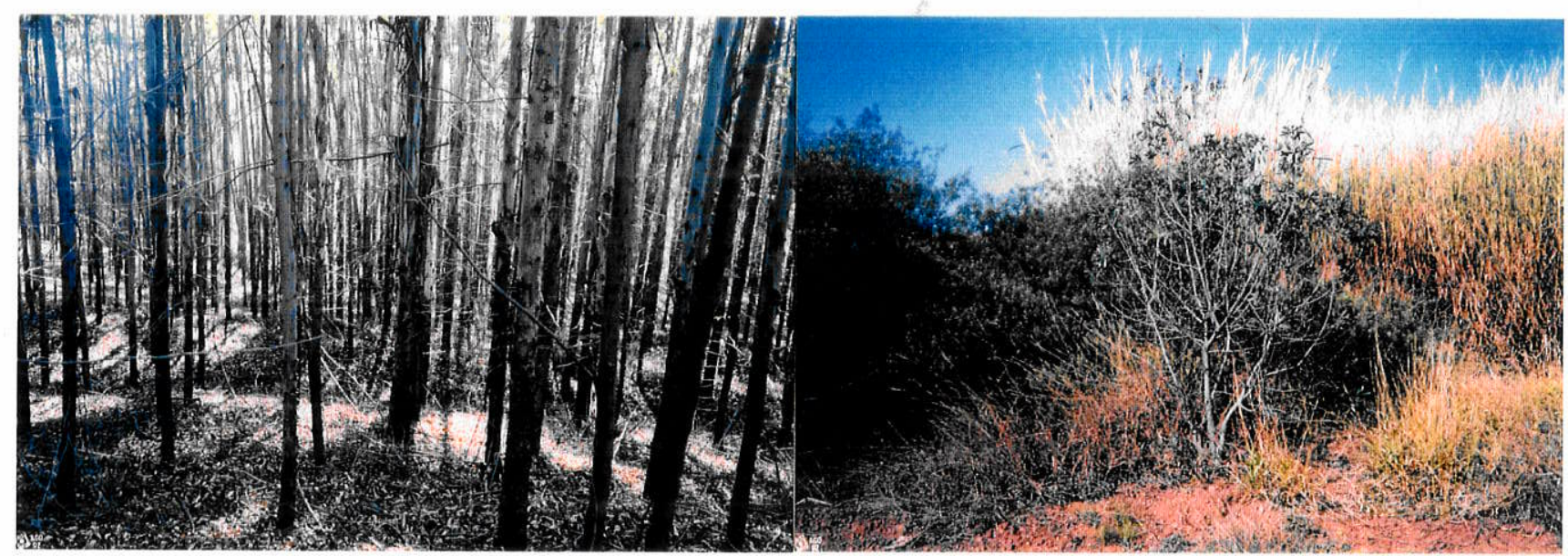

Foto 6 - Area 6 reabilitada há 12 anos

Foto 5B - Área 5 reabilitada há 3 anos

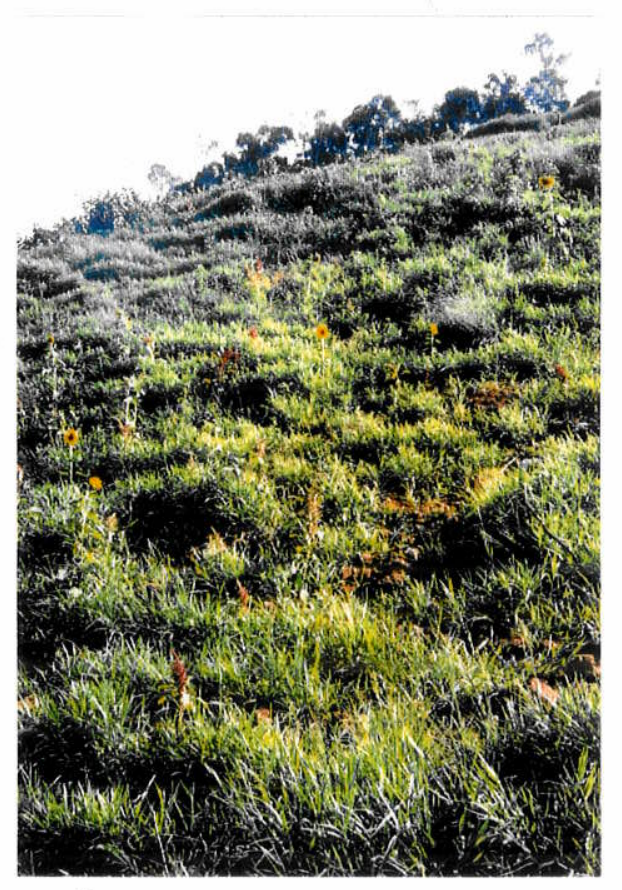

Foto 7 - Área 7 reabilitada há 7 meses

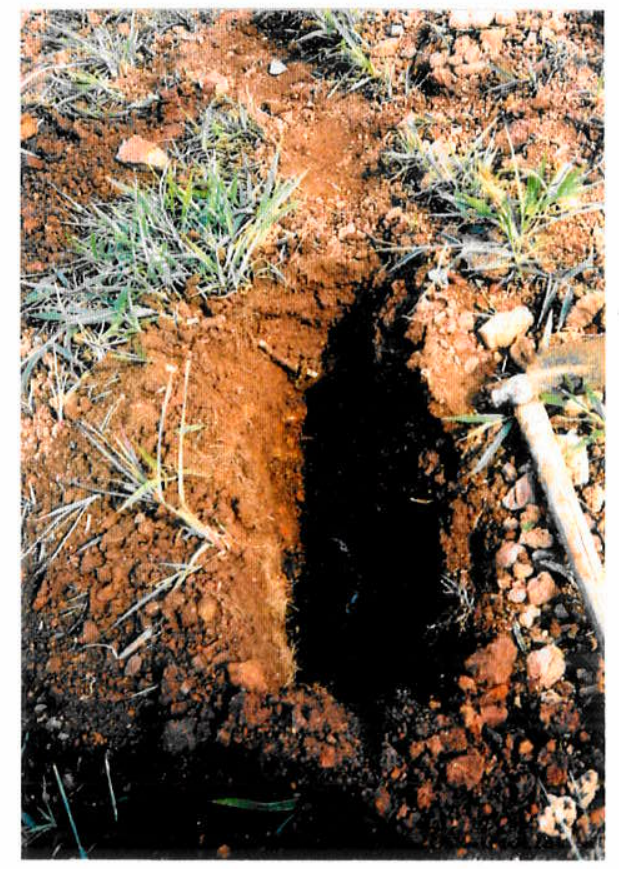

Foto $7 \mathrm{~A}$ - Perfil na Area $7 \mathrm{com} 7$ meses 
Cor - 5 YR $3 / 4$ nos $10 \mathrm{~cm}$ iniciais com nódulos de cor 7,5YR 5/6 ao longo do perfil na primeira visita. $\mathrm{Na}$ terceira visita cor $5 \mathrm{YR} 3 / 4$ entre $0-10 \mathrm{~cm}$ intercalado com material mais cinza-escuro, entre $10-30 \mathrm{~cm}$ cor $5 Y R$ $5 / 8$ com porções $7,5 Y R$ 5/8 mais compacta e entre 30 e $50 \mathrm{~cm}$ cor 2,5 YR 2/6 com manchas 10YR 7/8 e 5YR 6/8.

Textura - argilo-siltosa em todo perfil na primeira visita. Na terceira visita entre $0-20 \mathrm{~cm}$ argilo-siltosa, entre $20-50 \mathrm{~cm}$ partes com textura argilosa (cor $5 Y R$ 5/8) e partes arenosiltosa (cor 7,5YR 5/8).

Estrutura - Após 7 meses a superfície estava pouco erodida e a quantidade de nódulos era grande misturada ao material fino com porosidade boa. O "top-soil" e os demais materiais acamados ainda apresentavam as caracteristicas originais mas nenhuma estruturação estava nítida. Na terceira visita o desenvolvimento da "Cassia speciosa" era de uma capoeira e no perfil aberto já apareceu agregados arredondados associados aos nódulos e às raízes. Os nódulos milimétricos estavam envolvidos por material argiloso e por matéria orgânica, além das raizes, dando início a agregados. Volumes poliédricos estão individualizados por paredes lisas. As raizes mais grossas ao se aprofundarem pelas paredes dos poliédros abrem caminho para descida de material mais escuro, possivelmente matéria orgânica. Pode-se perceber o início de estruturação poliédrica e linhas de fantasmas das fraturas da rocha mãe até a profundidade de $1 \mathrm{~m}$. Porosidade fissural.

Atividade biológica - muitas formigas e dois tipos de raizes, as finas próximas à superficie associadas aos agregados e as mais grossas se aprofundando verticalmente.

Raízes - finas, formando um fino tapete à superfície e aparece uma camada de $5 \mathrm{~cm}$ de serapilhiera formada por restos de capim gordura. Raizes mais grossas aparecem nos primeiros $30 \mathrm{~cm}$ do perfil. 


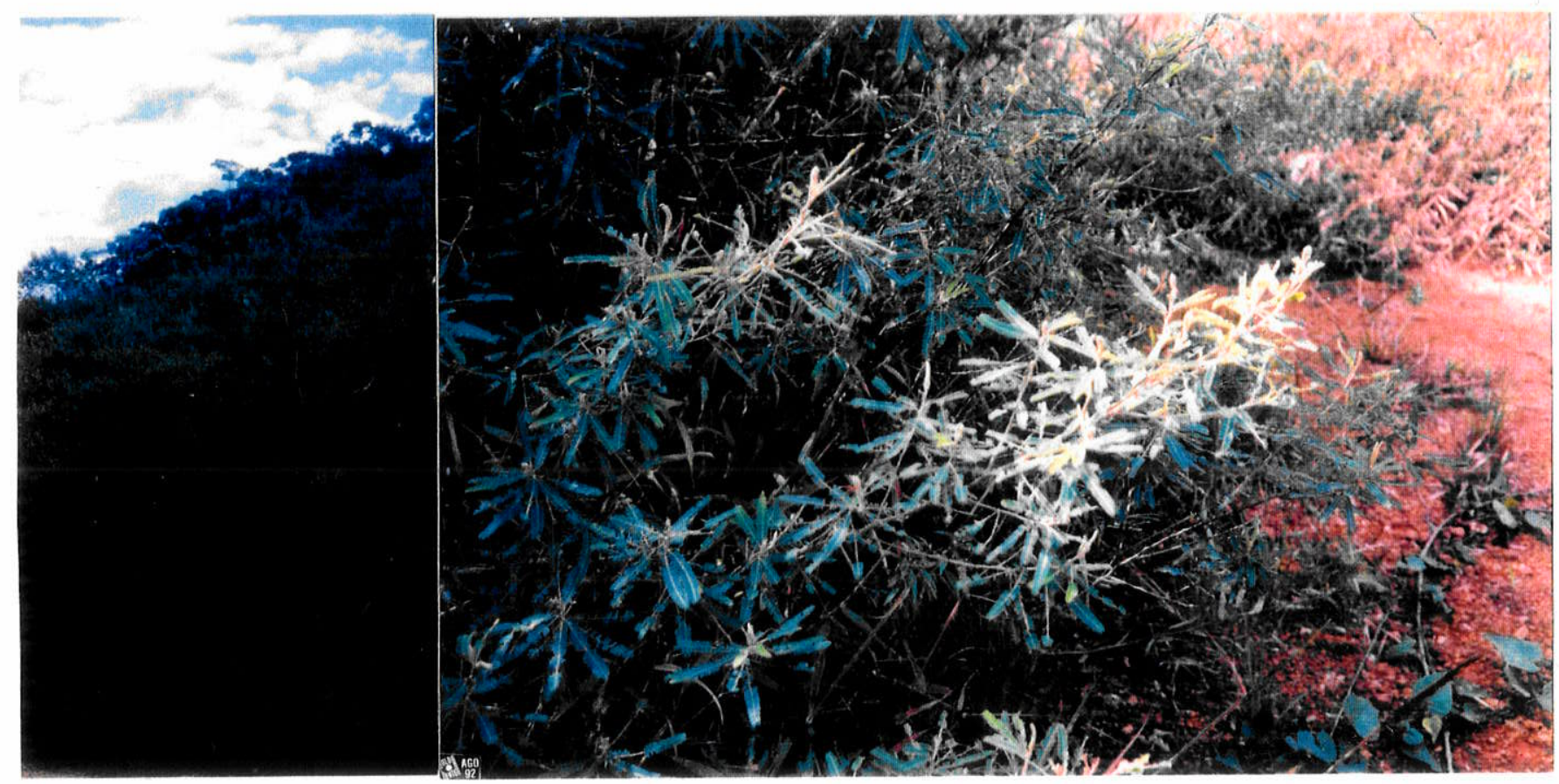

Foto 7 B - Area 7 reabilitada há 3 anos com Cassia speciosa

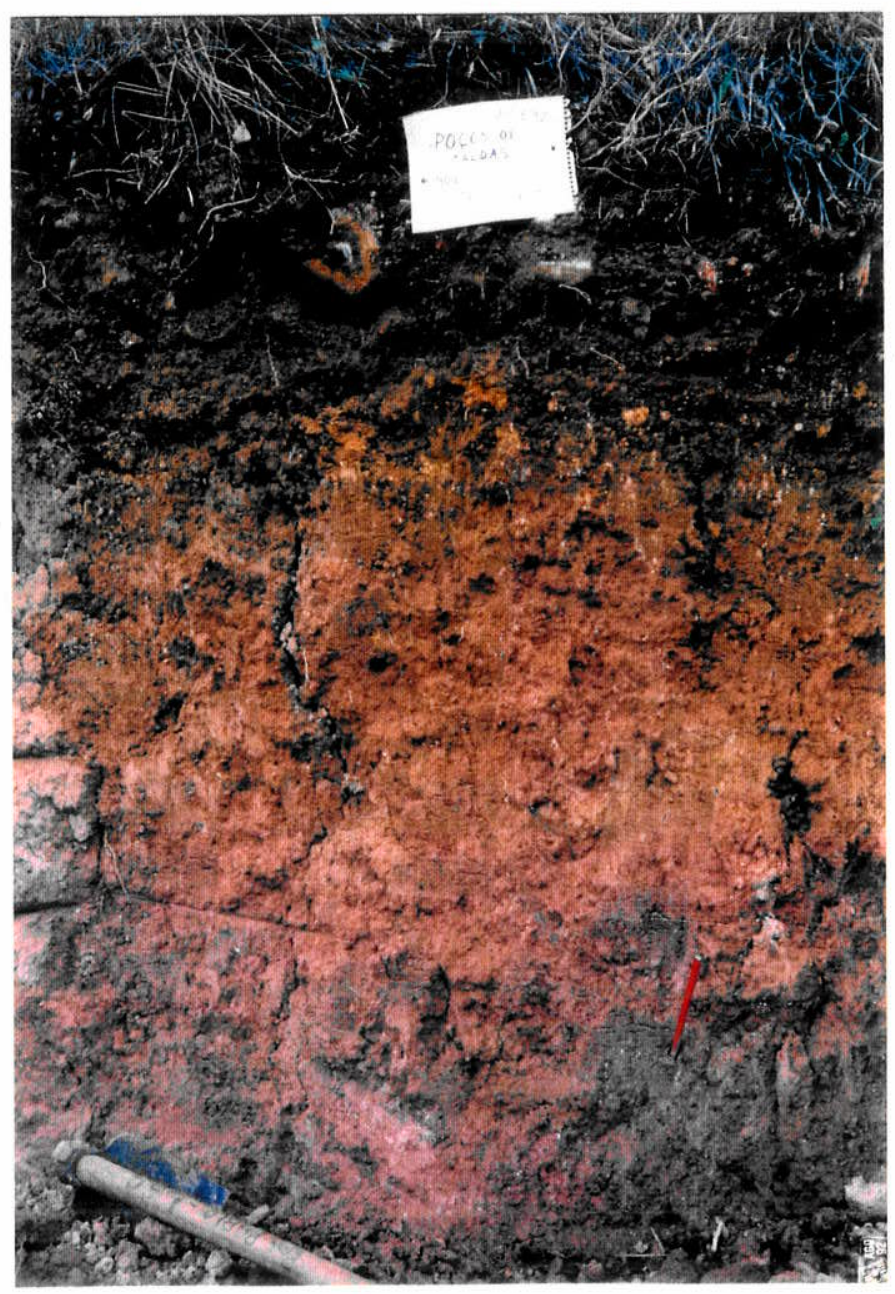

Foto $7 \mathrm{C}$ - Perfil aberto após 3 anos 
ÁREA 8 - Campo de Santa Rosália preparada por suavizamento (foto 8) usando o "top-soil" após distribuição dos fertilizantes e do pó calcário. A evolução foi acompanhada desde o preparo com amostragem e observaçōes em tres visitas. Esta área foi dividida em tres sub-áreas adjacentes que receberam revegetações diferentes

e entre a primeira e a segunda sub-áreas foi deixado um espaço de $40 \times 40 \mathrm{~m}$ sem revegetação, somente foram adicionados termofertilizante, "top-soil" e pó calcário.

Vegetação anterior - floresta subtropical

Posição na paisagem - meia encosta

Profundidade dos perfis $-50 \mathrm{~cm}$

Revegetação das sub-áreas - Primeira sub-área recebeu mudas de arbóreas e entre as mudas foi distribuida serapilheira retirada da mata próxima (foto $8 \mathrm{~A}$ ). Segunda subárea recebeu mudas de arbóreas $e$, como forrageiras, mistura de sementes de gramíneas inclusive de capim-gordura (Melinis minutiflora). Terceira sub-área recebeu mudas de arbóreas e, como forrageiras, sementes de espécies de gramíneas (tabela 3) sem o capim-gordura. O monitoramento das áreas foram diferentes. A primeira subárea foi visitada duas vezes, com sete meses e com três anos. A segunda área e a área-piloto adjacente foram visitadas após sete meses, após dois anos e após três anos e a terceira área foi visitada somete após dois anos. As áreas revegetadas receberam mudas de especies desenvolvidas no viveiro da companhia num espaçamento menor entre elas em relação às outras áreas, cerca de três metros uma da outra. 


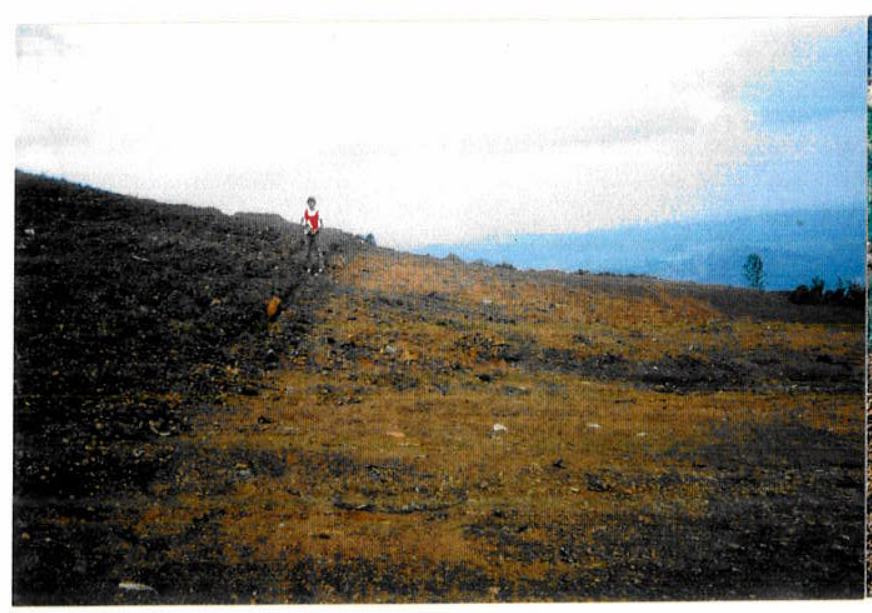

Foto 8 - Area 8 após preparo, parcialmente sub-solada

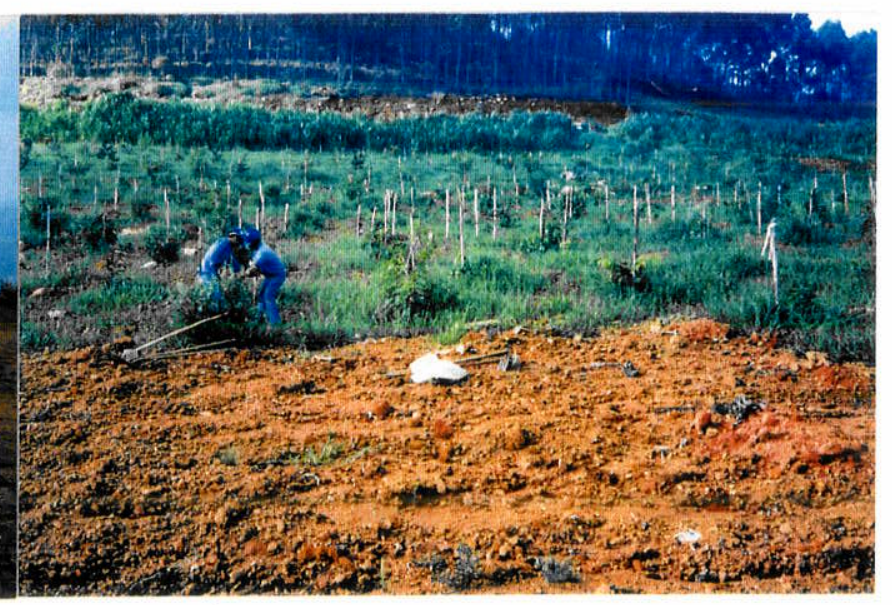

Foto 8B - Area 8 na sub-área revegetada junto à area-piloto depois de 7 meses



Foto 8A - Área 8 na sub-área que recebeu serapilheira

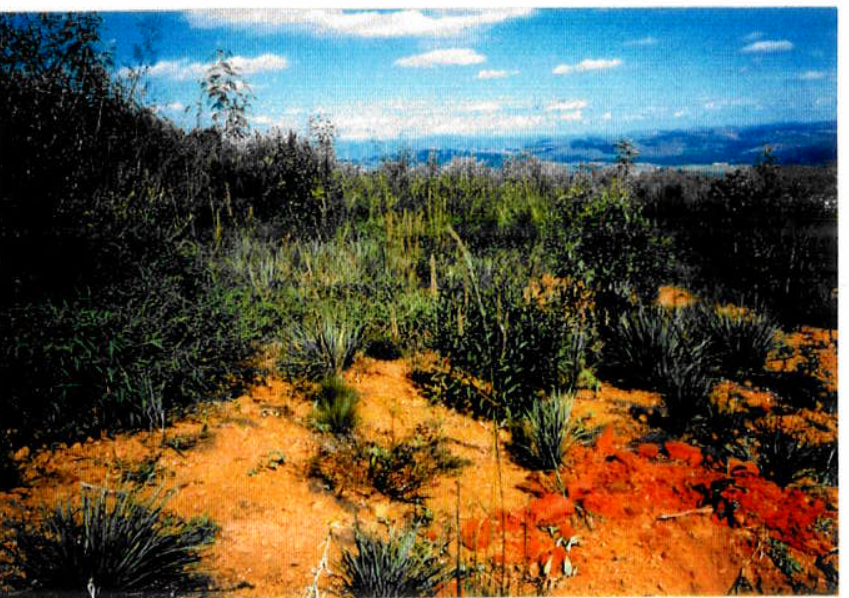

Foto 8C - Área 8 na sumbarea revegetada junto à área-piloto depois de 2 anos

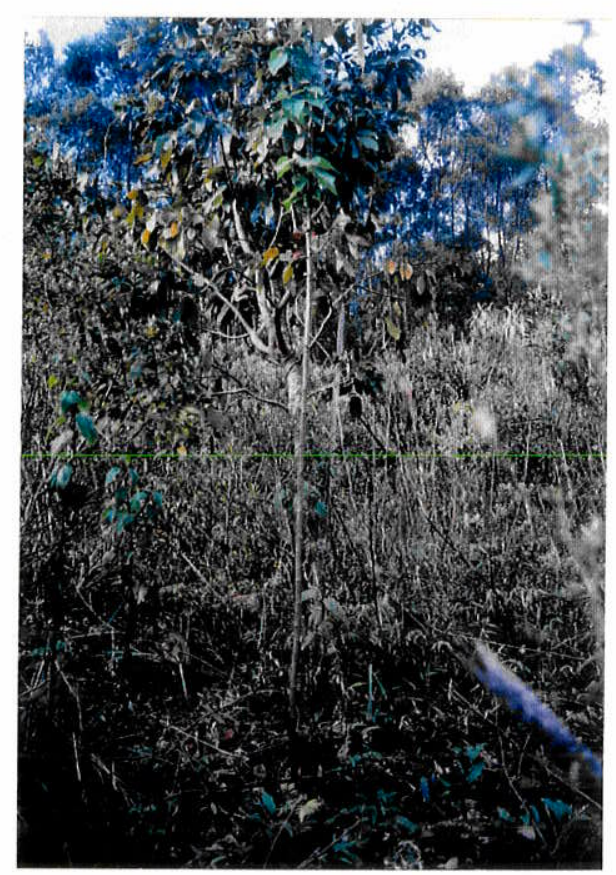



Foto 8D - Área 8 na 3a sub-área, desenvolvimento precário

Foto 8E - Área 8 na 1a. sub-área com serapilheira após 3 anos 


\section{Primeira sub-área}

Resutados da reabilitação - Na primeira visita não foi coletada amostra pois nảo havia desenvolvimento das espécies da serapilheira (foto 8A). Após três anos com a vegetação bem desenvolvida foi aberto um perfil e feitas coletas e observações. As espécies desenvolvidas (foto $8 \mathrm{E}$ ) eram de várias arbustivas e muitas samambaias $e$ sobre o solo muitos musgos. No perfil as evidências da erosão é grande pois a espessura do material não compactado varia entre 10 e $15 \mathrm{~cm}$.

Cor - Na terceira visita entre $0-3 \mathrm{~cm} 7,5 Y R 3 / 4$, entre $3-10 \mathrm{~cm} 7.5 Y R 5 / 8$, entre $10-40 \mathrm{~cm}$ intercalações de cores: 7,5YR 6/8 e 5YR 5/8.

Nódulos - $20 \%$ do volume com dimensões centimétricas e milimétricas.

Textura - Fortemente argilosa em todo o perfil

Estruturas - Poliédricas (colunas) de pequenas dimensões $5 \mathrm{~cm} \times 3 \mathrm{~cm}$ até $10 \mathrm{~cm}$ de profundidade, não aparecem agregados arredondados $e$ as raízes penetram pelas paredes dos poliédros. Abaixo as estruturas poliédricas são pouco definidas mas aparecem algumas paredes verticais lisas.

Atividade biológica - grande quantidade de diferentes espécies de formigas, muitos insetos, muitas folhas em decomposição sobre o solo e muitos musgos.

Raízes - finas e poucas em superfície, não formam tapete e muitas em torno das pequenas estruturas poliédricas.

\section{Segunda sub-área}

Resultado da reabilitação - Após 7 meses da revegetação esta sub-área apresenta um bom desenvolvimento das forrageiras e na área-piloto ao lado está sem vegetação (foto $8 \mathrm{~B}$ ). Na segunda visita, 2 anos após a revegetação, a vegetação estava bem desenvolvida, fechada pelas forrageiras e na área-piloto apareceram alguns tufos de gramineas nos sulcos da subsolagem possiveimente sementes trazidas pelo vento ou pelas chuvas (foto $8 \mathrm{C}$ ). Foram abertos dois perfis: um na área-piloto (foto $8 \mathrm{~F}$ ) e outro na área revegetada (foto $8 \mathrm{G}$ ). $\mathrm{Na}$ figura 7 está a descrição do perfil da área-piloto e na figura 8 a descrição do perfil da área revegetada. As diferenças são nítidas no que diz respeito ao desenvolvimento de raizes associadas a estruturação e a retenção de matéria orgânica, com uma passagem gradual do solo novo para o substrato enquanto que na área-piloto existe um pavimento de nódulos à superfície e o contato brusco entre o substrato e o solo novo. Isto mostra que a atividade das raízes e da vegetação foi decisivo para desenvolver o solo. Após três anos a vegetação ocupou a área-piloto com forrageiras e algumas arbustivas cujas sementes podem ter vindo das áreas adjacentes de mata natural e reabilitadas. Este fenômeno foi descrito por Ricklefs 




Foto 8 F - Perfil aberto na Área 8 sem revegetaçāo

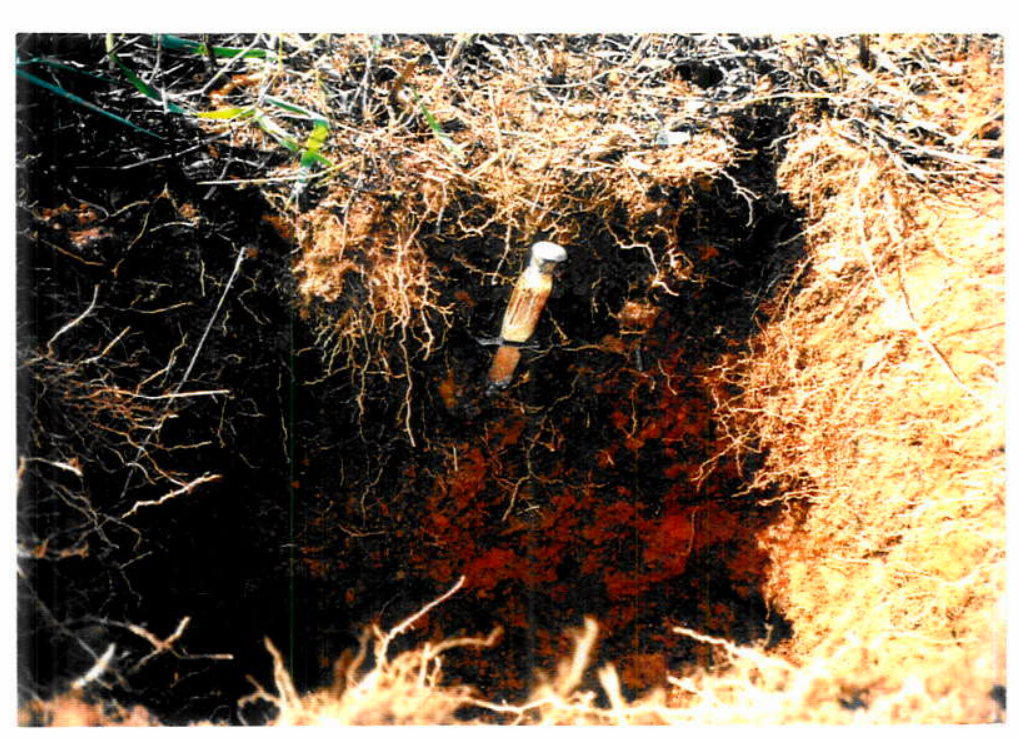

Foto $8 \mathrm{G}$ - Perfil aberto na Área $8 \mathrm{c} /$ capim-gordura e mudas
Peffil esquemátice na Area 8 sl revedetaczo

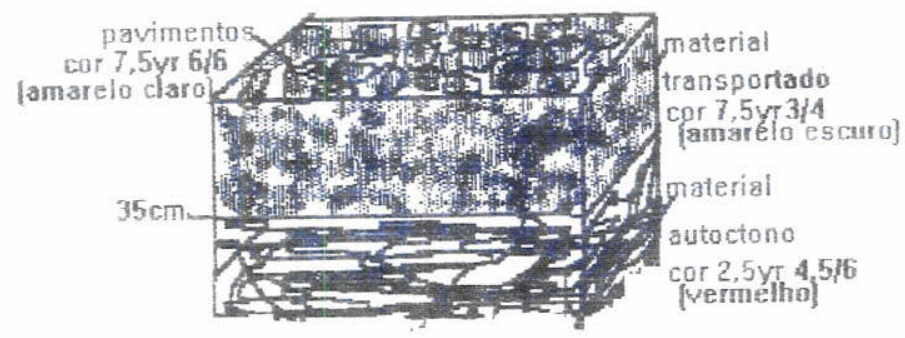

Fignra 6 - Pern! descritivo da foto 8 f
Perfil na parte revegetada há 1 ano

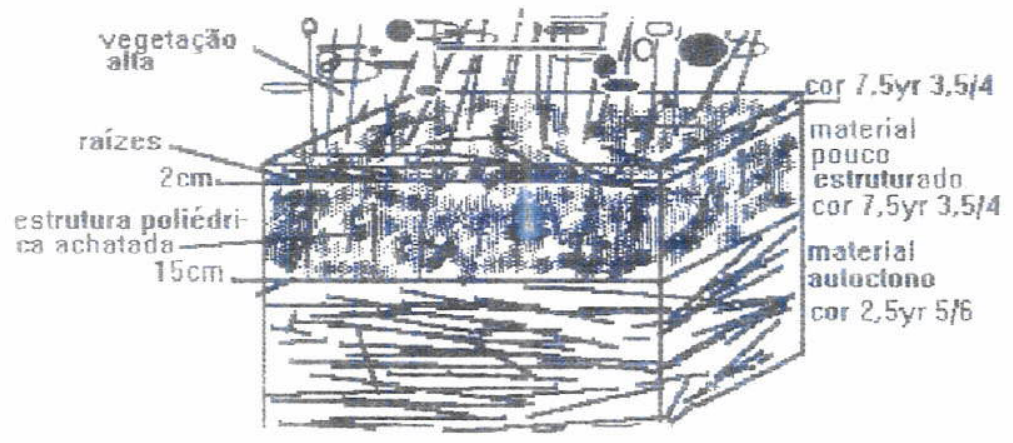

Figura 7 - Pernil describivo da foto $3 G$ 
(1987), discutindo o retomada das espécies existentes nos arredores. No caso em questão o preparo do substrato, mesmo sem revegetação, permitiu que sementes, trazidas das áreas próximas, germnassem.

Textura - na área piloto era argilo-siltosa na primeira visita. Na segunda visita argilosiltosa abaixo do pavimento de nódulos até o contato com o substrato fortemente argiloso. $\mathrm{Na}$ área revegetada à superfície, entre $0-10 \mathrm{~cm}$, a textura era silto-argilosa e entre $10-30 \mathrm{~cm}$ siltosa. Na segunda visita aparece uma textura argilo-areno-siltosa próxima à superfície $(0-5 \mathrm{~cm})$ formando agregados e abaixo argilo-siltosa até o contato com o substrato compacto muito argilosa.

Estruturas - $\mathrm{Na}$ área-piloto ocorre pavimento em superficie e não aparece qualquer vestígio de estruturação nas duas visitas e a porosidade é intersticial. Na área revegetada na primeira visita percebeu-se apenas volumes poliédricos achatados intercalados por raizes com porosidade fissural. Na segunda visita aparece um início de estruturação no material mais escurecido pela matéria orgânica $(0-20 \mathrm{~cm})$ e abaixo os poliédros achatados predominam. A prosidade é fissural.

Nódulos - aparecem à superfície formando pavimento na área-piloto e estão distribuídos ao longo do perfil como $20 \%$ do volume do material. $\mathrm{Na}$ área regevetada os nódulos milimétrico estão associados a estruturação, envolvidos por material fino, junto às raizes finas e em profundidade estão dispesos ( $20 \%$ do volume).

Cor - na área-piloto a cor à superfície era 7,4 YR $6 / 6$ e entre 2 e $35 \mathrm{~cm}$ a cor era 7,5 YR $3 / 4$, o substrato a partir de $35 \mathrm{~cm}$ era $2,5 \mathrm{YR} 4,5 / 6$. Na área revegetada a cor geral do perfil era 7,5YR 3,5/4 com pelotas de cor 2,5YR 6/5.

Atibidade biológica - nenhuma na área-piloto e na área revegetada intensa atividade de formigas e de minhocas, além das raizes finas.

Raízes - finas formando tapete à superficie na área revegetada. 
Resultado da reabilitação - Esta área que não recebeu o campi-gordura teve um desenvolvimento de gramíneas em tufos que não impediram a erosão e em pouco tempo a área ficou sem condições de desenvolver vegetação e obviamente de desenvolver solo (foto $8 \mathrm{D}$ ). Apesar deste problema a erosão não foi total, permanecendo material fino à superfície sob nódulos de diversas dimensões.

Nódulos - Os nódulos aparecem, à superfície, distribuídos irregularmente e predominam os milimétricos em relação aos centimétricos. Em profundidade os nódulos se distribuem na proporção de $20 \%$ do volume.

Textura - à superfície, areno-siltosa (entre $0-5 \mathrm{~cm}$ ), abaixo argilo-siltosa até $50 \mathrm{~cm}$.

Estruturas - Aparecem distribuídas aleatoriamente algumas estruturas colunares em partes onde predominam os nódulos maiores. $\mathrm{Na}$ áreas com nódulos menores não ocorre estruturação. Em profundidade as estruturas são descontinuidades associadas aos sulcos e perpendiculares a estas.

Atividade biológica - Nem raízes nem animais são importantes nesta área Raizes - raras, mais grossas em profundidade 


\subsubsection{DISCUSSÕES PARCIAIS}

O preparo por suavisamento é a opção mais eficiente porque, nas áreas terraceadas, os primeiros efeitos externos é a destruição dos vértices para suavisar o relevo, redistribuindo os materiais e desenvolvendo um novo relevo retardando o desenvolvimento da vegetação. Este fato foi observado na Área 4 onde as bancadas foram demostadas e o material rolado para a bancada imediatamente abaixo. A área no fim dos levantamentos de campo tinha 9 anos e pôde receber invasão de capimgordura porque os materiais ofereceram condições. Os materiais granulares acumulados nas bancadas mantiveram maior umidade e puderam fixar esta graminea.

Outro aspecto importante do preparo é a ripagem que revolve os materiais até a profundiade de $50 \mathrm{~cm}$ e diminui a erosão. Além disso ao longo do tempo ajuda no desenvolvimento dos volumes estruturais e torna o meio mais poroso, o que foi muito importante para o desenvolvimento vertical das raizes que, ao atingirem o substrato pós-minerado, não conseguem penetrar mais.

As espécies vegetais escolhidas para revegetação influiram muito no desenvolvimento do solo e de sua própria fixação. O capim-gordura é uma gramínea de desenvolvimento rápido mas șe não está associada a outras espécies ela seca e pode pegar fogo. As Áreas 2 e 7 tiveram este problema e por este motivo o uso desta graminea deve ser associado a outra espécie arbustiva, como por exemplo a Cassia speciosa que foi semeada na Área 7. Ela aproveita as raizes e os caules do capimgordura em decomposição como matéria orgânica para o solo. Esta associação na Área 7 favoreceu o desenvolvimento do horizonte "O"+A e da estruturação por agregados arredondados. Na Área 5 o capim-gordura somente se espalhou pela área após a semeadura de Cássia e do capim Napiê.

A estruturação dos solos naturais de floresta através de agregados arredondados, passa a ocorrer nos solos novos com o desenvolvimento das raizes finas em presença dos materiais preparados com "top-soil" com ocorreu nas Áreas 5,7 e 8. Este fato também ocorreu na Área 2 depois que o capim-gordura se desenvolveu.

A atividade biológica das raizes foi determinante na estruturação e na fixação $e$ condução da matéria orgânica. No caso da Área 2 as raízes superficiais iniciaram o envolvimento de pelotas aglutinadas à superfície do solo e passaram a penetrar pelos materiais desenvolvendo agregados. As formigas também são importantes porque escavam os materiais e constróem os formigueiros que passam a participar do 
ecossistema. As minhocas também mostraram sua atividade ałaptadas às novas condições, como no caso da Área 6 , onde os ninhos estavam distribuidos por todo o
perfil.

De um modo geral o preparo das áreas por suavisamento e adição de alterita é uma boa opção ajudada pela ripagem que diminui muito a erosão dos finos. Mas o fator decisivo é a fixação dos finos pelas raízes finas, desenvolvendo estruturação e o capim-gordura associado a Cassia speciosa foram as espécies vegetais mais apropriadas para esta fase da reabilitação. Os benefícios com uso de fertilizantes, de termofertilizantes, de pó calcário e de "top-soil" sobre os materiais preparados estão relacionados ao desenvolvimento da vegetação num primeiro momento e depois podem estar associados aos processos pedogenéticos. 


\subsection{CARACTERIZAÇÃO DOS MATERIAIS DOS SOLOS}

4.2.1. CARACTERIZAÇÃO FISICA, QUIMICA, FÍSICO-QUIMICA E MINERALÓGICA DOS MATERAIS

4.2.1.1. pH, U.R., \%C, M.O.T. e composição mineralógica

As medidas de $\mathrm{pH}$, de umidade residual, de carbono, de matéria orgânica e a composição mineralógica foram realizadas nos solos naturais e novos em amostras deformadas coletadas a cada $10 \mathrm{~cm}$, da superficie até a profundidade de $50 \mathrm{~cm}$ para se avaliar como estes dados poderiam mostrar as diferenças e as semelhanças entre os solos naturais e novos. As áreas que foram monitoradas tiveram mais de uma amostragem. Os resultados das análises granulométricas foram plotados em diagramas triangulares de textura (figura $8 \mathrm{~A}$ ) e estão interpretados de acordo com o gráfico da capacidade de retenção de água (figura $8 \mathrm{~B}$ ). Estes estudos estão apresentados separadamente.

\begin{tabular}{|c|c|c|c|c|c|}
\hline Área 1 & $0-10 \mathrm{~cm}$ & $10-20 \mathrm{~cm}$ & $20-30 \mathrm{~cm}$ & $30-40 \mathrm{~cm}$ & $40-50 \mathrm{~cm}$ \\
\hline pH & 3.96 & 3.81 & 4.14 & 4.33 & 4.31 \\
\hline U.R. (\%) & 3.43 & 4.66 & 3.93 & 3.54 & 4.29 \\
\hline C (\%) & 4.25 & 3.56 & 2.82 & 2.36 & 1.65 \\
\hline M.O.T. $(\mathrm{g} / 60 \mathrm{~g})$ & 4.31 & 10.05 & 3.52 & 14.49 & 5.95 \\
\hline
\end{tabular}

Tabela 6 - Caracterização dos materiais da Área 1 


\begin{tabular}{|c|c|c|c|c|c|c|c|c|c|c|}
\hline \multirow[t]{2}{*}{ Área 2} & \multicolumn{2}{|c|}{$0-10 \mathrm{~cm}$} & \multicolumn{2}{|c|}{$10-20 \mathrm{~cm}$} & \multicolumn{2}{|c|}{$20-30 \mathrm{~cm}$} & \multicolumn{2}{|c|}{$30-40 \mathrm{~cm}$} & \multicolumn{2}{|c|}{$40-50 \mathrm{~cm}$} \\
\hline & $1 \mathrm{a} v$ & $2 \mathrm{a} v$ & $1 \mathrm{a}_{\mathrm{v}}$ & $2 \mathrm{a} v$ & $1 \underline{a}_{v}$ & $2 \mathrm{a} v$ & $1 \mathrm{a} v$ & $2 \mathrm{a} v$ & $1 \mathrm{a} v$ & $2 \underline{a} v$ \\
\hline $\mathrm{pH}$ & 6.15 & 5,61 & 4,79 & 4.72 & 4.61 & 4.55 & 4.28 & 4.22 & 4.96 & 5.15 \\
\hline U.R. (\%) & 1.69 & 3.92 & 2.69 & 3.59 & 2.23 & 1.88 & 2.74 & 0.80 & 1.87 & $\therefore$ \\
\hline$C(\%)$ & 0.25 & 0.36 & 0.09 & 0.12 & 0.07 & 0.07 & 0.13 & 0.15 & 0.13 & 0.13 \\
\hline M.O.T. $(\mathrm{g} / 30 \mathrm{~g})$ & 1.33 & 1.71 & 1.31 & 1.53 & 1.26 & 0.91 & 1.26 & 0.31 & - & - \\
\hline
\end{tabular}

Tabela 7 - Caracterização dos materiais da Área 2

\begin{tabular}{|c|c|c|c|c|c|}
\hline Área 3 & $0-10 \mathrm{~cm}$ & $10-20 \mathrm{~cm}$ & $20-30 \mathrm{~cm}$ & $30-40 \mathrm{~cm}$ & $40-50 \mathrm{~cm}$ \\
\hline $\mathrm{pH}$ & 3.70 & 3.91 & 4.01 & 4.18 & 4.26 \\
\hline U.R. (\%) & 5.12 & 6.37 & 4.00 & 4.17 & 3.64 \\
\hline C (\%) & 6.20 & 4.25 & 2.40 & 1.97 & 1.84 \\
\hline M.O.T. $(\mathrm{g} / 60 \mathrm{~g})$ & 6.77 & 13.42 & 4.15 & 2.80 & 2.46 \\
\hline
\end{tabular}

Tabela 8 - Caracterização dos Materiais da Área 3

\begin{tabular}{|c|c|c|c|c|c|c|c|c|c|c|}
\hline \multicolumn{1}{|c|}{ Área 2 } & \multicolumn{2}{|c|}{$0-10 \mathrm{~cm}$} & \multicolumn{2}{c|}{$10-20 \mathrm{~cm}$} & \multicolumn{2}{c|}{$20-30 \mathrm{~cm}$} & \multicolumn{2}{c|}{$30-40 \mathrm{~cm}$} & \multicolumn{2}{c|}{$40-50 \mathrm{~cm}$} \\
\hline & centro & borda & centro & borda & centro & borda & centro & borda & centro & borda \\
\hline pH & 5.49 & & 5.96 & & 5.66 & & 5.69 & & 5.45 & \\
\hline U.R. (\%) & 2.53 & 2.00 & 3.20 & 0.92 & 2.58 & 0.96 & 1.87 & 0.94 & 1.35 & 1.02 \\
\hline C (\%) & 1.22 & 1.08 & 1.24 & 0.25 & 0.72 & 0.15 & 0.51 & 0.08 & 0.43 & 0.03 \\
\hline M.O.T. $(\mathrm{g} / 30 \mathrm{~g})$ & 1.49 & 0.60 & 1.92 & 0.00 & 1.11 & 0.05 & 1.00 & 0.03 & 1.16 & 0.01 \\
\hline
\end{tabular}

Tabela 9 Características dos materiais da Área 4 


\begin{tabular}{|c|c|c|c|c|c|c|c|c|c|c|}
\hline \multirow[t]{2}{*}{ Área 5} & \multicolumn{2}{|c|}{$0-10 \mathrm{~cm}$} & \multicolumn{2}{|c|}{$10-20 \mathrm{~cm}$} & \multicolumn{2}{|c|}{$20-30 \mathrm{~cm}$} & \multicolumn{2}{|c|}{$30-40 \mathrm{~cm}$} & \multicolumn{2}{|c|}{$40-50 \mathrm{~cm}$} \\
\hline & $1 \mathrm{a} v$ & $2 \mathrm{a} v$ & $1 \mathrm{a}_{\mathrm{v}}$ & 2 a v & $1 \mathrm{a} v$ & $2 \underline{a}$ & $1 \mathrm{a} v$ & $2 a_{v}$ & $1 \underline{a} v$ & 2 a $v$ \\
\hline $\mathrm{pH}$ & 3.78 & - & 3.74 & - & 3.82 & $=$ & 3.73 & & 3.89 & - \\
\hline U.R. (\%) & 3.25 & $\begin{array}{l}a-2.21 \\
b-3.35 \\
\end{array}$ & 4.09 & $\begin{array}{l}a-2.16 \\
b-2.46 \\
\end{array}$ & 3.14 & $\begin{array}{l}a-1.82 \\
b-2.21 \\
\end{array}$ & 6.26 & $\begin{array}{r}a-2.41 \\
a-2.39 \\
\end{array}$ & 4.85 & $a-1.87$ \\
\hline C (\%) & 1.45 & - & 1.27 & - & 1.20 & - & 0.94 & & 0.89 & 0.13 \\
\hline M.O.T. $(g / 30 \mathrm{~g})$ & 2.73 & $\begin{array}{l}a-1.20 \\
b-1.57 \\
\end{array}$ & 2.57 & $\begin{array}{l}a-0.22 \\
b-2.88 \\
\end{array}$ & 1.93 & $\begin{array}{l}a-1.24 \\
b-1.00\end{array}$ & 2.03 & $\begin{array}{l}a-1.68 \\
b-1.40 \\
\end{array}$ & 1.72 & $\begin{array}{l}a-0.62 \\
b-1.40\end{array}$ \\
\hline
\end{tabular}

Tabela 10 Características dos materiais da Área 5

\begin{tabular}{|c||c|c|c|c|c|}
\hline Área 6 & $0-10 \mathrm{~cm}$ & $10-20 \mathrm{~cm}$ & $20-30 \mathrm{~cm}$ & $30-40 \mathrm{~cm}$ & $40-50 \mathrm{~cm}$ \\
\hline $\mathrm{pH}$ & 4.12 & 4.49 & 4.32 & - & - \\
\hline U.R. (\%) & 3.22 & 2.73 & 3.30 & - & - \\
\hline C $(\%)$ & 2.02 & 2.08 & 1.78 & - & - \\
\hline M.O.T. $(\mathrm{g} / 50 \mathrm{~g})$ & 3.40 & 5.27 & 2.50 & - & - \\
\hline
\end{tabular}

Tabela 11 Caracteristicas dos materais da Ȧrea 6

\begin{tabular}{|c||c|c|c|c|c|c|c|c|c|c|}
\hline \multirow{2}{*}{ Área 7 } & \multicolumn{2}{|c|}{$0-10 \mathrm{~cm}$} & \multicolumn{2}{c|}{$10-20 \mathrm{~cm}$} & \multicolumn{2}{c|}{$20-30 \mathrm{~cm}$} & \multicolumn{2}{c|}{$30-40 \mathrm{~cm}$} & \multicolumn{2}{c|}{$40-50 \mathrm{~cm}$} \\
\hline & $1 \mathrm{a} v$ & $2 \mathrm{a} v$ & $1 \mathrm{a} v$ & $2 \mathrm{a} v$ & $1 \mathrm{a} v$ & $2 \mathrm{a} v$ & $1 \mathrm{a} v$ & $2 \mathrm{a} v$ & $1 \mathrm{a} v$ & $2 \mathrm{a} v$ \\
\hline $\mathrm{pH}$ & 4.77 & 4.57 & 5.34 & 4.78 & 4.87 & 4.88 & 4.54 & 4.50 & 4.64 & 4.50 \\
\hline U.R. (\%) & 2.00 & 4.47 & 0.90 & 5.80 & 0.96 & 3.39 & 0.94 & 3.59 & 1.02 & 3.50 \\
\hline C (\%) & 0.70 & 1.20 & 0.16 & 1.02 & 0.10 & 0.98 & 0.11 & 0.54 & 0.16 & 0.45 \\
\hline M.O.T. $(\mathrm{g} / 30 \mathrm{~g})$ & 1.91 & 6.30 & 2.32 & 7.6 & 0.29 & 2.3 & 0.58 & 1.9 & 0.33 & 1.10 \\
\hline
\end{tabular}

Tabela 12 Características doa materias da Área 7 


\begin{tabular}{|c|c|c|c|c|c|}
\hline $\begin{array}{c}\text { Área 8 } \\
\text { 1a sub-área }\end{array}$ & $0-10 \mathrm{~cm}$ & $10-20 \mathrm{~cm}$ & $20-30 \mathrm{~cm}$ & $30-40 \mathrm{~cm}$ & $40-50 \mathrm{~cm}$ \\
\hline pH & 3.70 & 3.81 & 3.78 & 3.40 & 3.60 \\
\hline U.R. (\%)2.68 & 2.68 & 1.88 & 2.06 & 1.90 & - \\
\hline C (\%) & 2.48 & 2.55 & 2.00 & 1.20 & 0.9 \\
\hline M.O.T. & 1.08 & 0.72 & 0.87 & - & - \\
\hline
\end{tabular}

\begin{tabular}{|c||c|c|c|c|c|}
\hline $\begin{array}{c}\text { Área 8 } \\
\text { 2a sub-área }\end{array}$ & $0-10 \mathrm{~cm}$ & $10-20 \mathrm{~cm}$ & $20-30 \mathrm{~cm}$ & $30-40 \mathrm{~cm}$ & $40-50 \mathrm{~cm}$ \\
\hline pH & 3.49 & 3.55 & 3.38 & 3.32 & 3.32 \\
\hline U.R. (\%) & 3.25 & 3.29 & 3.38 & 1.90 & 1.43 \\
\hline C (\%) & 2.14 & 2.09 & 1.43 & 0.75 & 0.25 \\
\hline M.O.T. & $\star$ & $*$ & $*$ & $\star$ & $\star$ \\
\hline
\end{tabular}

\begin{tabular}{|c|c|c|c|c|c|}
\hline $\begin{array}{c}\text { Area 8 } \\
\text { área-piloto }\end{array}$ & $0-10 \mathrm{~cm}$ & $10-20 \mathrm{~cm}$ & $20-30 \mathrm{~cm}$ & $30-40 \mathrm{~cm}$ & $40-50 \mathrm{~cm}$ \\
\hline $\mathrm{pH}$ & 3.75 & 3.91 & 3.57 & 3.42 & 3.77 \\
\hline U.R. (\%) & 3.76 & 2.99 & 2.89 & 1.86 & 2.21 \\
\hline C (\%) & 1.97 & 1.42 & 1.24 & 1.00 & 0.63 \\
\hline M.O.T. & $*$ & $*$ & $*$ & $\star$ & $*$ \\
\hline
\end{tabular}

* Os resultados da M.O.T. não foram considerados porque ocorreu hidratação das amostras ou seja o peso final foi maior que o peso inicial.

Tabela 13 - Caracteristicas dos materiais da Área 8.

Os resultados das análises mineralógicas por Difração de Raios $X$ apresentaram como resultados a presença de gibbsitas, caulinitas e goethitas em todos os niveis. $A$ partir destes resultados esta composição mineralógica foi adotada como a predominate para os materiais entre as profundidade de $0-50 \mathrm{~cm}$ nos solos novos e naturais. 


\subsubsection{TEXTURA DOS SOLOS}

A textura dos solos foi interpretada pelo Diagrama da Textura do Solo adotado pela Associação Internacional do Solo (figura 9 A) e com estes resultados foi feito o estudo do efeito da textura na capacidade do solo de reter água (figura $\mathrm{9B}$ ).

De acordo com a textura dos solos a água pode ser retida mais fortemente ou pode passar mais facilmente através dos solos. As águas retidas podem estar disponivel para as planta ou podem estar fortemente adsorvidas às partículas argilosas, e as águas que passam rapidamente pouco se prestam à nutrição das plantas e às reações pedogeoquímicas.

As análises foram realizadas com materiais de diferentes profundidades para as quais foram escolhidos os sehuintes simbolos: $0-2 \mathrm{~cm}(\boldsymbol{t}) ; 0-10 \mathrm{~cm}(\Delta), 10-20 \mathrm{~cm}(\bullet)$, $20-30 \mathrm{~cm}(\square), 30-40 \mathrm{~cm}(\$)$ e $40-50 \mathrm{~cm}(\$)$ e o diagrama triangular distribui os valores relativos das argilas, dos siltes e das areias. A figura 9 apresenta os diagramas 1 a 6 , a figura 10 apresenta os diagramas 6 a 12 e a figura 11 os diagramas 12 a 15 . Segue comentário sobre a interpretação da textura dos solos relacionada a capacidade de retenção da água pelos solos.

Área 1 (figura 9, diagrama 1)

$0-10 \mathrm{~cm}$ - textura argilo-siltosa, pouca água gravitacional, muita água disponivel para as plantas e muita água adsorvida, $10-20,20-30,30-40 \mathrm{~cm}$ - textura argilosa fracamente siltosa, as mesmas características do volume acima,

40-50 cm - textura argilosa fracamente arenosa, pouca água gravitacional, muita água disponivel para as plantas e adsorvida.

Área 2 após 3 anos de reabilitação (figura 9, diagrama 2)

$0-10 \mathrm{~cm}$ - textura areno-siltosa, muita água disponivel para as plantas, pouca água gravitacional e adsovida.

$10-20,20-30,30-40$ e $40-50 \mathrm{~cm}$ - textura siltosa fracamente arenosa, muita água disponivel para as plantas e pouca água gravitacional e adsorvida.

Área 2 após 6 anos de reabilitação (figura 9, diagrama 3) 
0-10cm - textura areno-silte-argilosa - muita água disponivel fara as plantas e adsorvida e pouca água gravitacional,

$10-20 \mathrm{~cm}$ - areno-siltosa - muita água gravitacional, boa quantidade disponivel para as plantas e pouca água adsorvida,

20-30, 30-40 e 40-50cm - argilo-siltosa - pouca água gravitacional, muita água disponivel para as plantas e adsorvida

Área 3 (figura 9, diagrama 4)

$0-10$ e $10-20 \mathrm{~cm}$ - textura siltosa fracamente arenosa - pouca água gravitacional, muita água disponivel para as plantas e pouca água adsorvida,

20-30 e $30-40 \mathrm{~cm}$ - textura argilo-siltosa - quase nenhuma água gravitacional, muita água disponível para as plantas e muita água adsorvida,

$40-50 \mathrm{~cm}$ - textura argilosa - nenhuma água gravitacional, muita água para as plantas e muita água adsorvida.

Área 4 após 6 anos de reabilitação (figura 9, diagrama 5)

0-10, 10-20cm - textura areno-siltosa - muita água disponivel para as plantas e pouca água gravitacional e adsorvida,

$20-30 \mathrm{~cm}$ - textura argilo-silte-arenosa - muita água disponivel para as plantas e adsorvida e pouca água gravitacional,

30-40 e 40-50cm - textura areno-siltosa - muita água disponivel para as plantas e pouca água gravitacional e adsorvida.

Área 5 após 1 ano de reabilitação (figura 9, diagrama 6)

0-10, $10-20$ e $20-30 \mathrm{~cm}$ - textura silto-argilosa - pouca água gravitacional, muita água disponívl para as plantas e muita água adsorvida.

Área 5 após 2 anos de reabilitação (figura 10, diagrama 7)

$0-10,10-20,20-30,30-40$ e 40-50cm - textura argilosa fracamente arenosa - pouca água gravitacional, muita água disponivel para as plantas e adsorvida. 

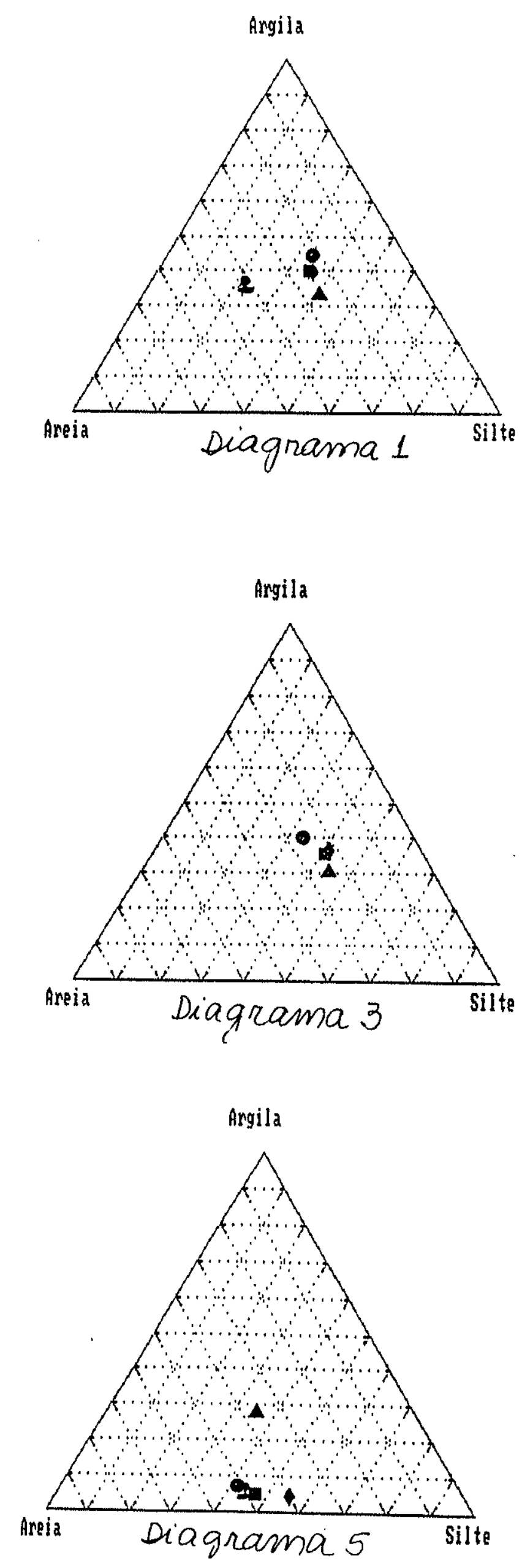
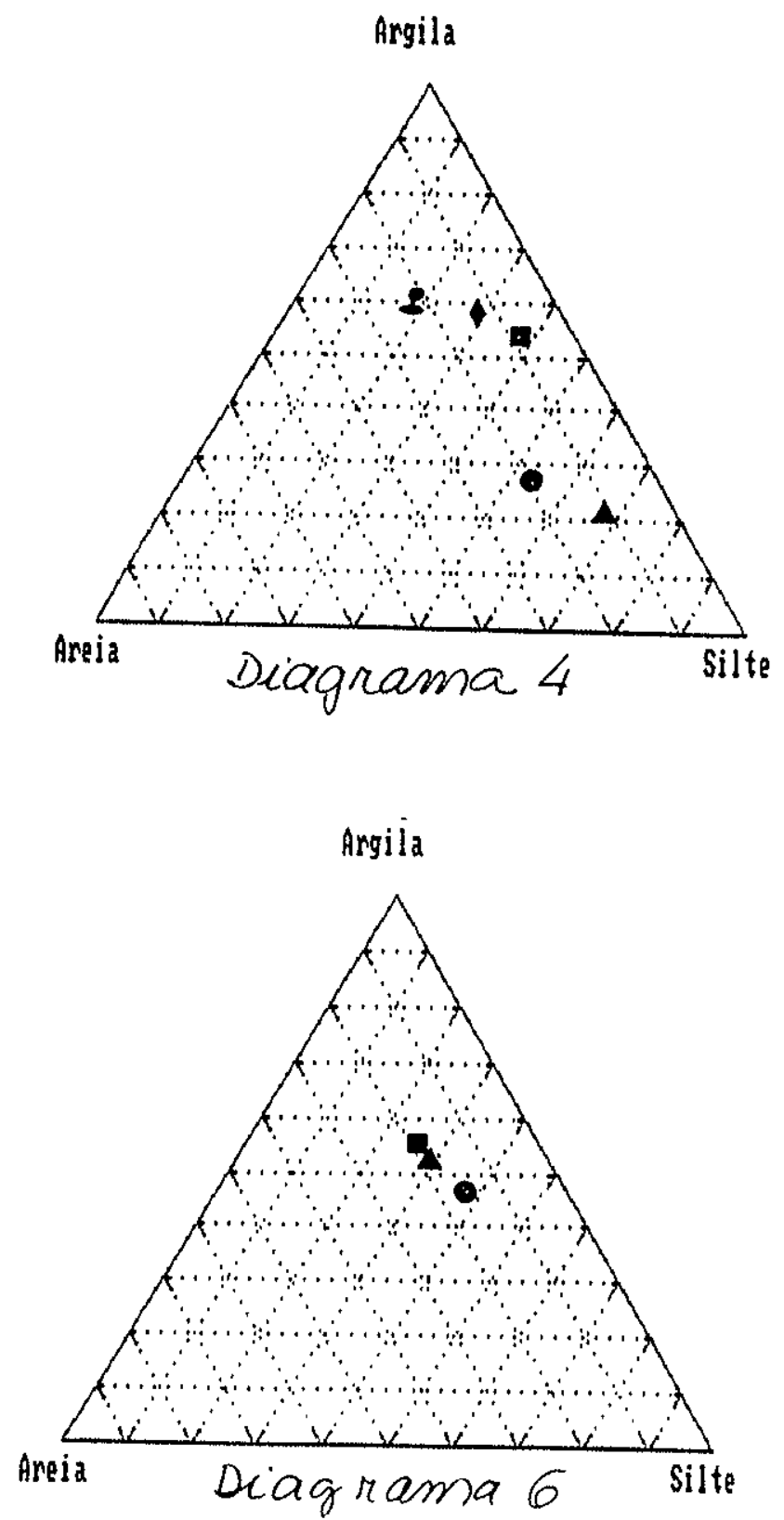

Flgura 9. Dlagramas de Textura dos Solo: Dlagrama 1 - Área 1; Dlagrama 2 - Área 2 reabilitada há 3 anos; Dlagrama 3 - Área reablitada há 6 anos; Dlagrama 4 - Área 3: Dlagrama 5 - Área 4 reabilitada há 6 anos; Dlagrama 6 - Área 5 reabllitada há 7 


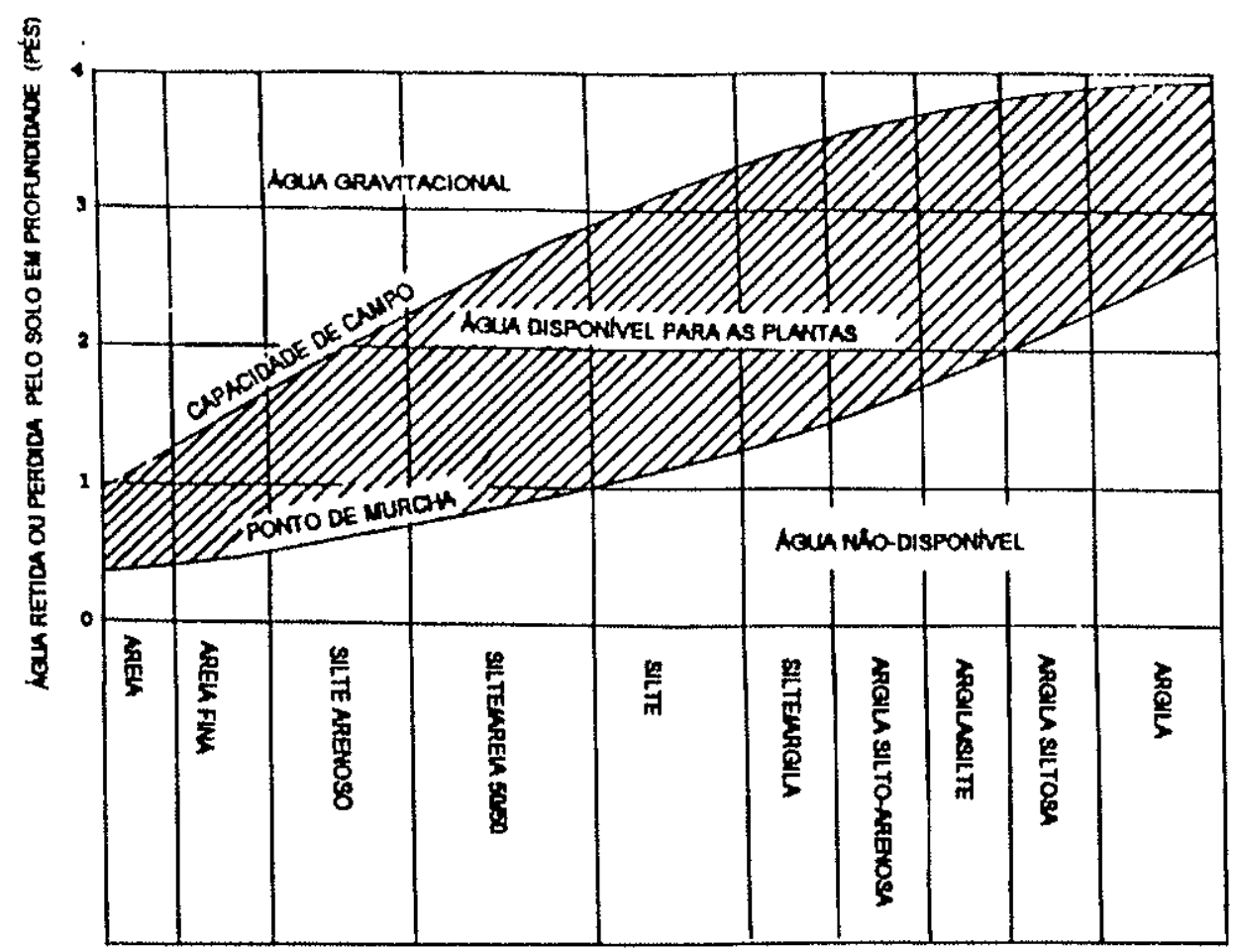

Figura 9B - Gráfico do estudo do efeito da textura na capacidade do solo de reter água (USDA 1961)

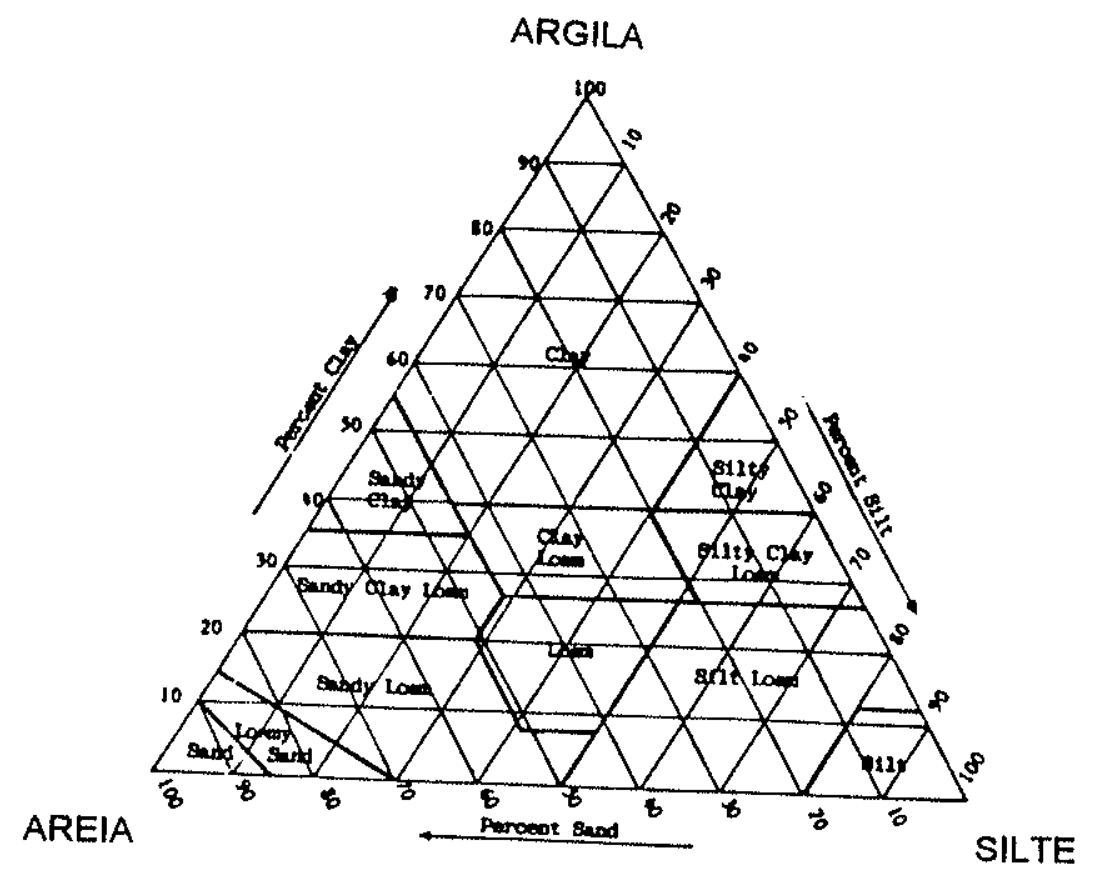

Figura 9A - Diagrama da Textura dos Solos (Associação Internacional de Solos) 
Área 5 após 3 anos de reabilitação (figura 10, diagrama 6)

0-10 e 10-20cm - textura arenosa fracamente argilosa - muita água gravitacional, menos água disponinel para as plantas e pouca água adsorvida

20-30, 30-40 e 40-50cm - textura argilo-silte arenosa - pouca água gravitacional, muita água disponivel para as plantas e adsorvida.

Área 6 após 14 anos de reabilitação (figura 10, diagrama 9)

0-10, $10-20$ e $20-30 \mathrm{~cm}$ - textura silto-argilosa - pouca água gravitacional, muita água disponivel para as plantas e adsorvida,

30-40 e 40-50cm - argilo-siltosa - quase nenhuma água gravitacional, muita água disponivel para as plantas e adsorvida.

Área 7 após 7 meses de reabilitaçäo (figura 10, diagrama 10)

0-10, 10-20,20-30,30-40 e 40-50cm - textura areno-siltosa - muita água gravitacional, suficiente água disponível para a vegetação e pouca água adsorvida

Área 7 após 3 anos de reabilitação (figura 10, diagrama 11)

$0-10,10-20,20-30,30-40$ e 40-50 cm - textura silte-argilosa - pouca água gravitacional, muita água disponivel para as plantas e adsorvida.

Área 8 na parte da área-piloto após 7 meses de reabilitação (figura 10, diagrama 12)

0-10, $10-20$ e $20-30 \mathrm{~cm}$ - silte-argilosa - pouca água gravitacional, muita água disponivel para as plantas e adsorvida

$30-40$ e $40-50 \mathrm{~cm}$ - areno-siltosa - muita água gravitacional, suficiente água disponivel para as plantas e pouca água adsorvida.

Área 8 na parte revegetada com capim-gordura após 7 meses de reabilitação (figura 11, diagrama 13)

$0-10,10-20,20-30 \mathrm{~cm}$ - textura silte-argilosa - pouca água gravitacional, muita água disponível para as plantas e adsorvida 

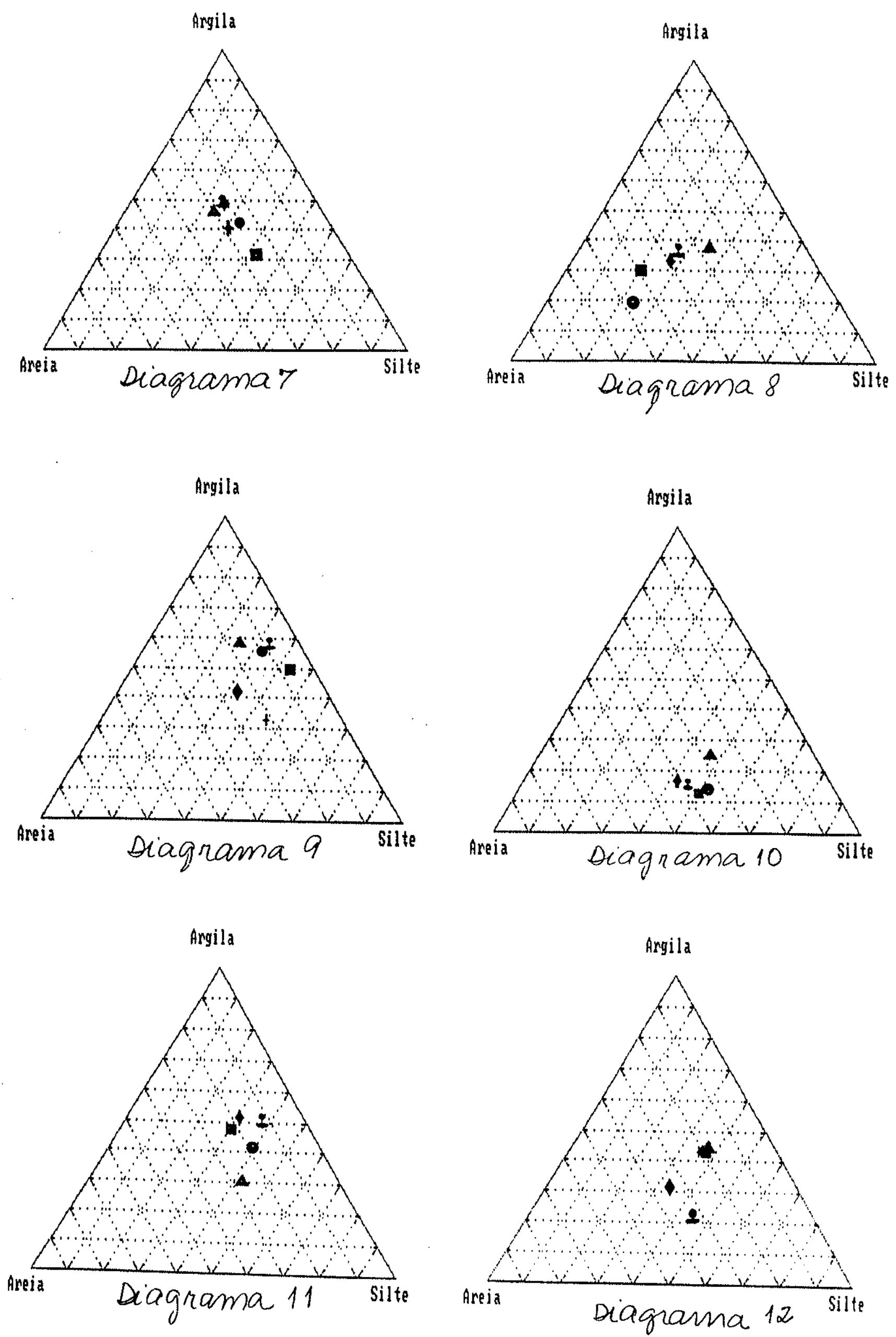

Flgura 10. Dlagramas de Textura do Solos: Diagrama 7 - Área 5 reabilltada há 2 anos; Dlagrama 8 - Área 5 reabilitada há 3 anos; Dlagrama 9 - Área 6 reabilitada há 15 anos; Diagrama 10 - Área 7 reabilitada há 7 meses; Diagrmama 11 - Área 7 reabilitada há 2 anos; Dlagrama 12 - Área 8 na área-piloto após 7 meses. 
$30-40$ e $40-50 \mathrm{~cm}$ - textura areno-siltosa - muita água gravitacional, suficiente água disponivel para as plantas e pouca água adsorvida.

Área 8 na parte que recebeu serapilheira, após três anos de reabilitação (figura 11, diagrama 14)

0-10 e $10-20 \mathrm{~cm}$ - textura areno-siltosa - muita água gravitacional, sufucuente água disponivel para as plantas e pouca água adsorvida

20-30 e $30-40 \mathrm{~cm}$ - areno-silte-argilosa - pouca água gravitacional, muita água disponível para as plantas e muita águas adsorvida.

"Top-soil" usado sobre o preparo da Área numa camada interrompida, de aproximadamente $3 \mathrm{~cm}$ (figura 11, diagrama 15)

Textura argilosa fracamente siltosa - quase nenhuma água gravitacional, muita água disponivel para as plantas e adsorvida.

\subsubsection{DISCUSSÖES PARCIAIS}

As diferenças entre o $\mathrm{pH}$ dos solos naturais e os solos novos, os novos valores maiores que os naturais deve-se provavelmente ao uso de calcário como corretivo de acidez sobre o terreno, porque em profundidade o $\mathrm{pH}$ é muito semelhante em todas as áreas, em torno de 4.00. O gráfico da figura 12 reúne as medidas de $\mathrm{pH}$ em todas as áreas, para comparar o comportamento do $\mathrm{pH}$ entre elas e em profunidade. Os solos naturais apresentam pH ácido variando de 3.7 a 4.2. Alguns solos novos apresentam o $\mathrm{pH}$ próximo dos valores dos solos naturais, mas alguns solos novos que apresentaram valores variando de 5 a 6 provavelmente pelo tratamento com pó calcário.

O teor de carbono nos solos naturais é significativamente maior que nos solos novos, entretanto estes valores aumentam com o desenvolvimento da reabilitação. As áreas reabilitadas a mais tempo apresentam teores mais elevados que as áreas reabilitadas mais recentemente (figura 13). Analisando os teores matéria orgânica a situação é similar entre os solos naturais e novos(figura 14) mas observando os valores encontrados nos solos novos, durante a monitoragem, ficou claro que os valores aumentaram significativamente (tabela 13) com a fixação da vegetação, o que favoreceu a estruturação próximo à superfície. Onde o "top-soil" ficou mais à superfície, sem revolvimento (Área 8) o desenvolvimento das forrageiras foi grande associado ao desenvolvimento do capim-gordura. Sem o capim gordura (Área 8 , 

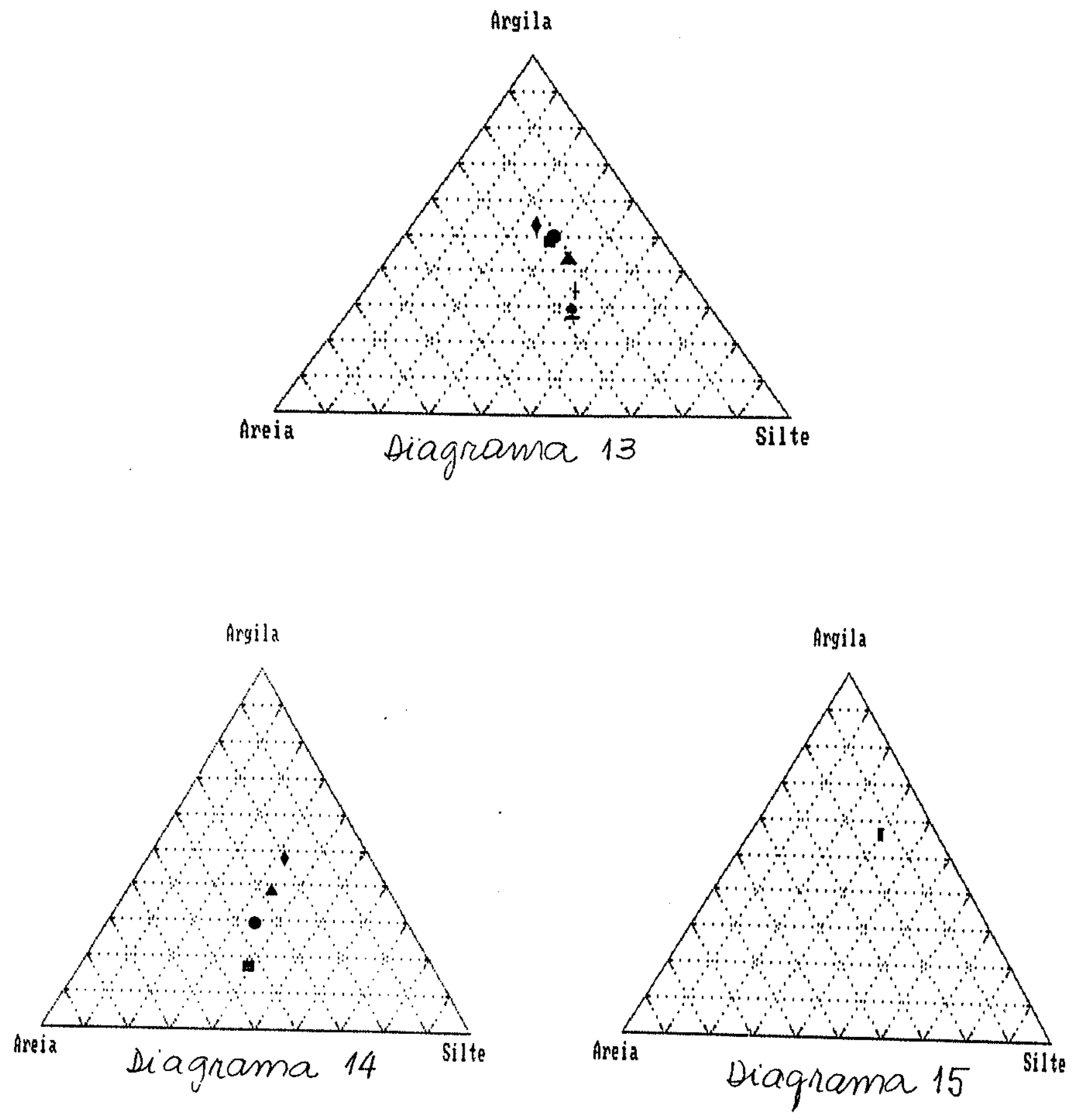

Figura 11. Dlagrama de Textura dos Solos: Dlagrama 13 - Área 8 revegetada há 7 meses; Dlagrama 14 - Área 8 reabilltada com serapilhelra há 3 anos; Dlagrama 15 -
Textura do "top-soll". 


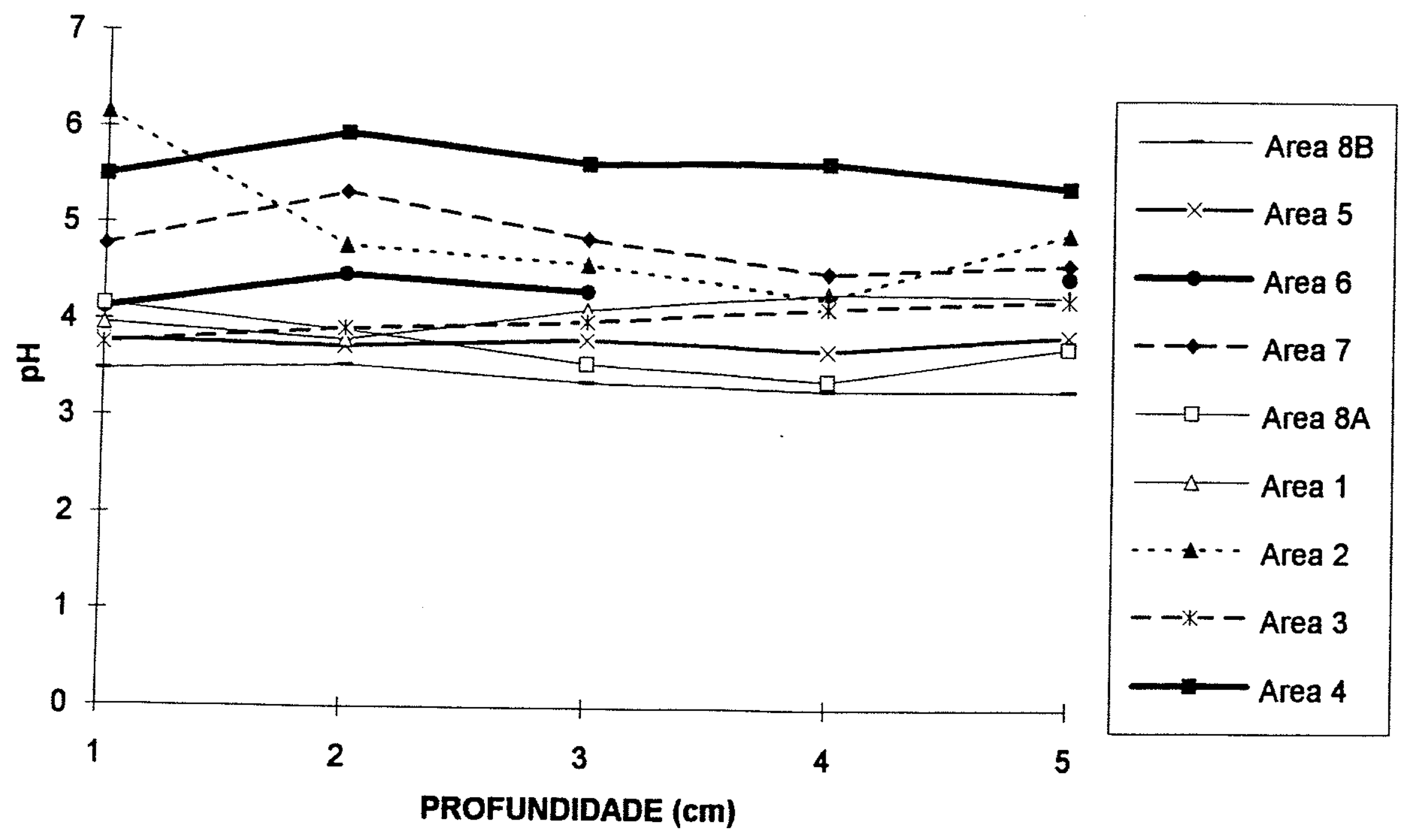

Figura 12. Gráficos das medidas de pH das áreas estudadas. 




Figura 13. Gráfico do Carbono dos materiais estudados 
terceira sub-Área) as forrageiras não tiveram o mesmo sucesso. De maneira geral a fixação e o aumento dos teroes de matéria orgânica ocorre associado ao desenvolvimento da vegetação, que por sua vez participa da reestruturação dos solos.

A umidade residual (U.R.) mostrou ser um parâmetro associado ao desenvolvimento dos solos. No gráfico da figura 15 pode-se ver que os solos naturais apresentam valores maiores de U.R. que os novos e entre os novos o desenvolvimento da estruturação (e da vegetação) está associado a aumento da U.R. (tabelas 8,11 e 13) Desta maneira é possivel concluir que a disponibilidade de materiais finos nos solos é importante se ocorrer fixação rápida da vegetação para favorecer a reestruturação, caso contrário os finos são lavados e a revegetação fica prejudicada. Mesmo tendo condiçōes de reter água os materiais finos mantêm esta água no solo se houver biota associada. $O$ estudo da textura é importante mas todos os demais fatores que participam da revegetação devem existir. Os solos novos com maiores valores de umidade residual também contêm maiores valores de matéria orgânica, mostrando a capacidade higroscópica desta última.

O preparo por bancadas sofre no decorrer do tempo uma estabilização com desmonte das bancada, mas o efeito negativo pode ser percebido nas bordas da área, que são erodidas e perdem matéria orgânica junto com os materiais finos. Este fenômeno foi medido na Área 4, que apesar do bom desenvolvimento da vegetação, o desenvolvimento do solo não é homogêneo, enquanto que as áreas suavisadas sofrem erosão muito menos acentuada e desenvolvimento homogêneo.

A composição mineralógica dos materiais está mostrada no gráfico típico da difrações de Raio $X$ da figura 16 , onde se vê a predominância de gibbsita, tanto bem cristalizada (picos bem definidos) como mal cristalizada (picos mais arredondados), aparecendo também caulinita bem e mal cristalizada e goethita. 


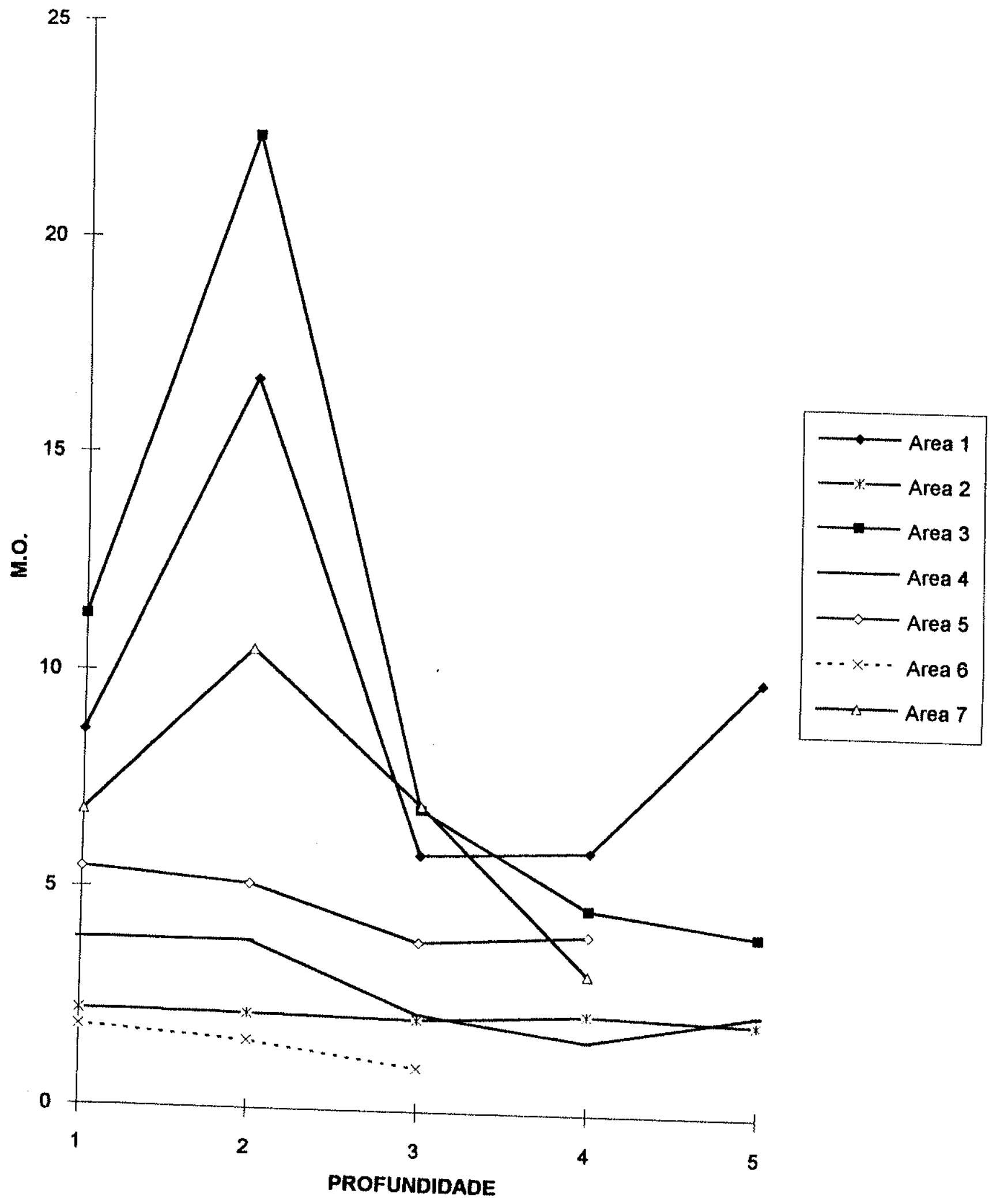

Figura 14. Gráfico da Matéria Orgânica dos materiais estudados 


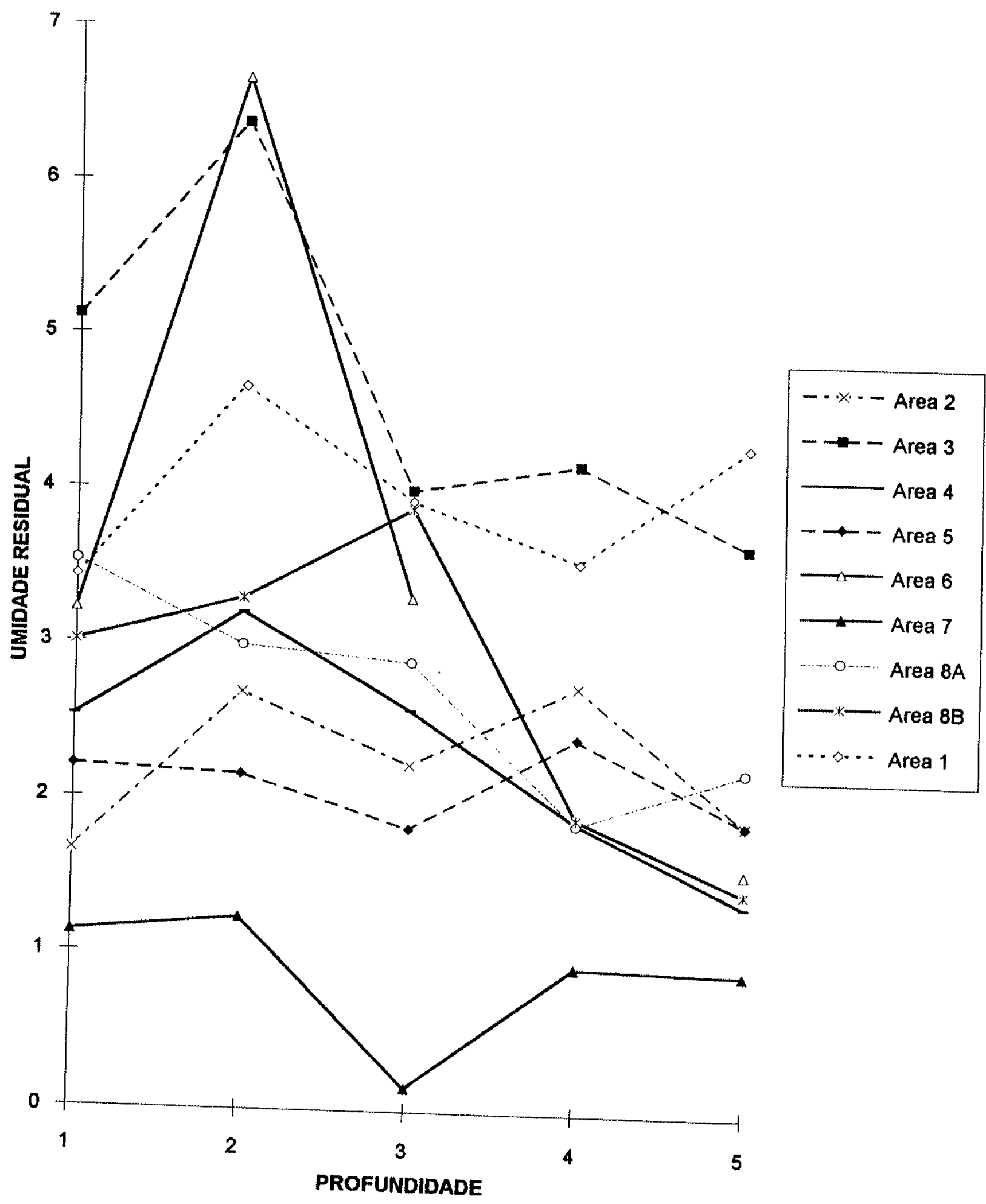

Figura 15. Gráfico da Umidade Residual dos materiais estudados 


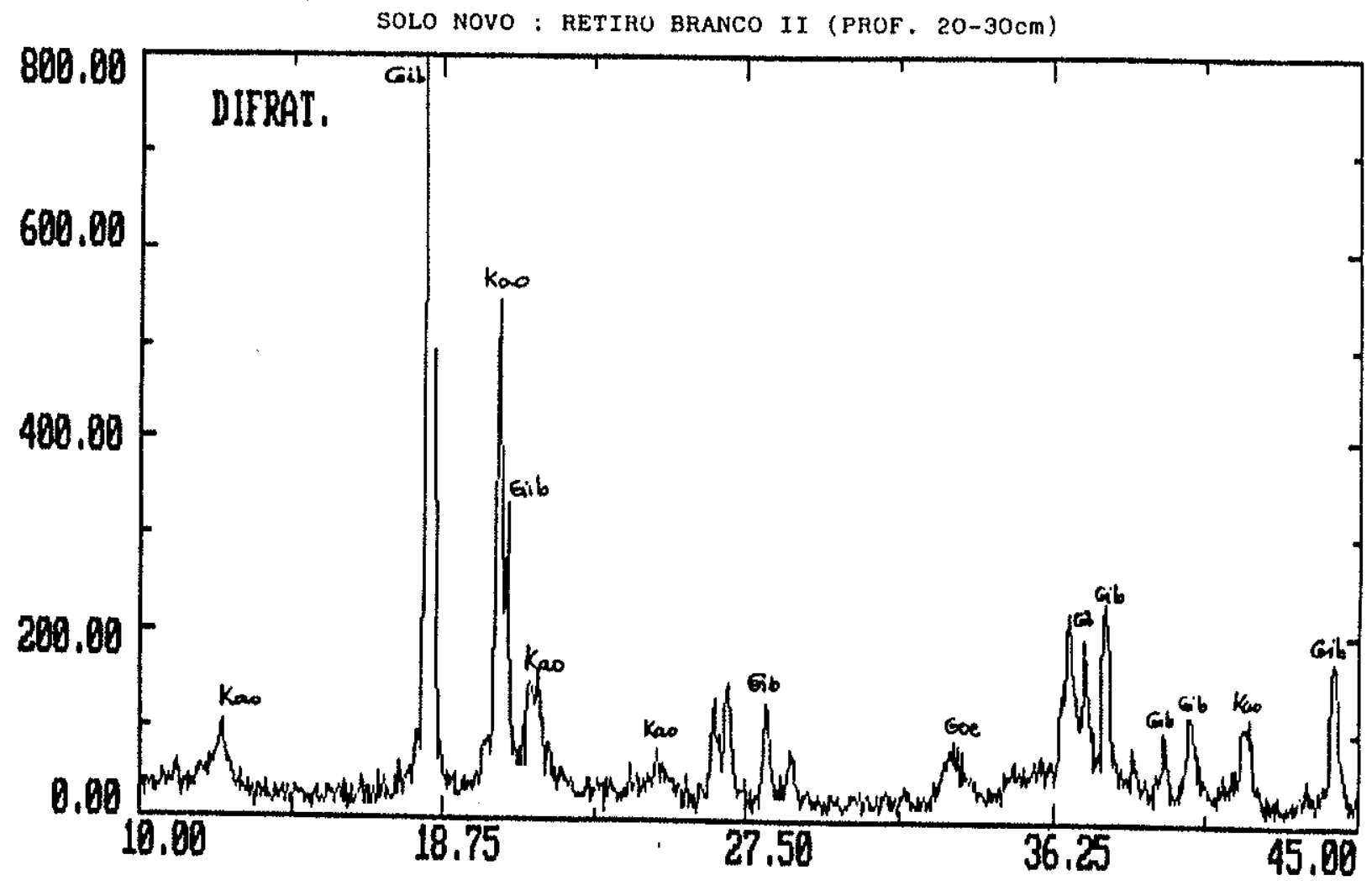

Figura 16 - Difratograma típico das análises de Difração de Raio X dos solos 


\subsubsection{ESTUDOS MICROMORFOLÓGICOS E MICROGEOQUIMICOS}

\subsubsection{ESTUDOS AO MICROSCÓPIO ÓPTICO}

As lâminas de amostras indeformadas de solos naturais e novos foram observadas para o estudo dos aspectos morfológicos utilizando o microscópio óptico polarizante. Muitas imagens foram fotografadas para ilustrar o estudo e foram objeto de maior atenção as feições dos materiais mais próximos da superfície (entre $0-15 \mathrm{~cm}$ ), para conhecer a influência dos processos pedogeoquímicos sobre os solos reabilitados.

As observações de lâminas ao microscópio permitem conhecer o arranjo dos materiais dos solos e a distribuição dos vazios ou poros, além de identificar os minerais secundários, os diferentes tipos de plasmas, as pedofeiçōes relacionadas e a presença de revestimentos (cutãs) relacionados aos processos pedogenéticos.

Estes estudos foram realizados em duas partes: a primeira em solos naturais e a segunda em solos novos.

\section{a) Estudo microscópico dos solos naturais}

Predominam nos solos naturais em niveis próximos à superficie $(0-30 \mathrm{~cm})$ dois tipos de plasma, um incolor predominante, com ataque de material ferruginoso em pontos pequenos disseminados por toda a superfície, além de matéria orgânica também fartamente distribuída, e outro com cores amarelas, alaranjadas e avermelhadas que são prolongamentos dos plasmas brancos, desprendido de suas bordas por fraturamentos (plasma terciário).

Entre 0 e $20 \mathrm{~cm}$ os grãos são da ordem de 1 a $1,5 \mathrm{~mm}$ e os fragmentos do plasma colorido se partem em pequenos granulos que ficam agrupados entre as fissuras maiores. As fissuras maiores medem 4 a $5 \mathrm{~mm}$ e as intragrãos $0,003 \mathrm{~mm}$ de largura. Os pequenos grânulos que se desprendem são envolvidos por matéria orgânica e formam microagregados. Aparecem muitos fragmentos de tecidos vegetais e de carapaças de animais distribuídos pelos plasmas. A presença destes fragmentos revelam intensa atividade biológica (fotos 9,10 e 11). 


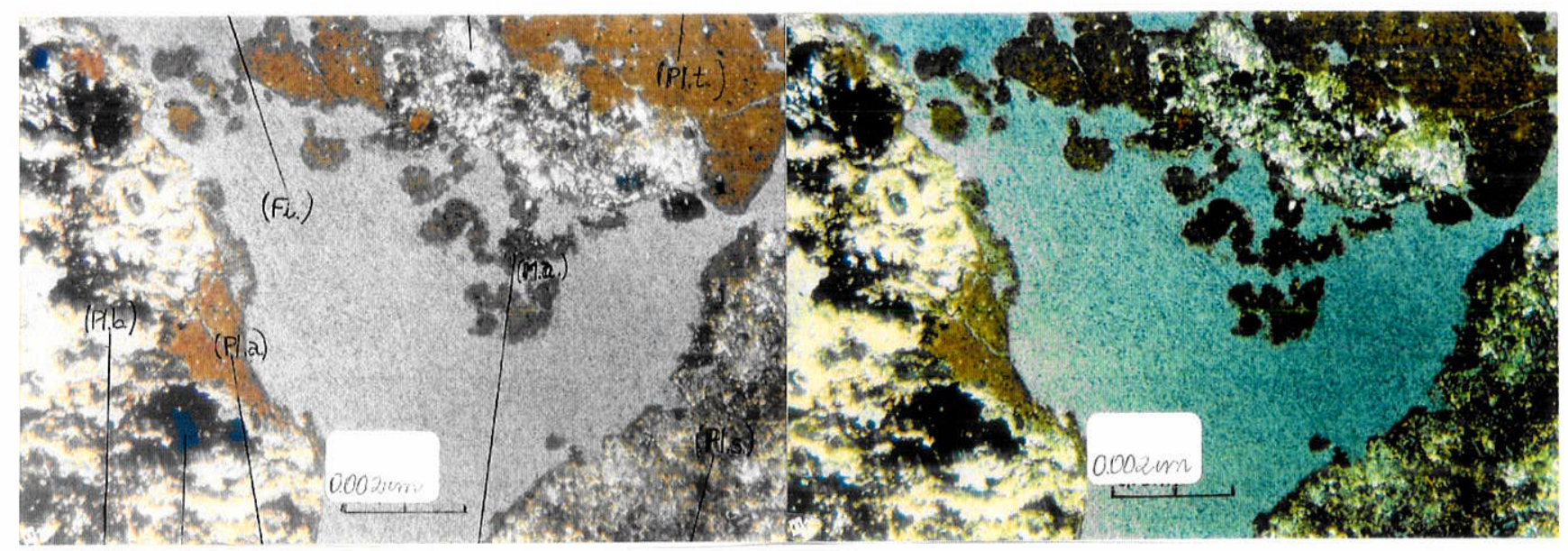

FOTO 9 - Fissura ramificada (Fi) separando plasma branco secundário (PI.s.) com plasma amarelo nas bordas (PI.t.) - estrutura aglomeroplásmica. Presença de microagregados (M.a.). À esquerda, luz natural e à direita nícois cruzados (solo natural de campo cerrado).

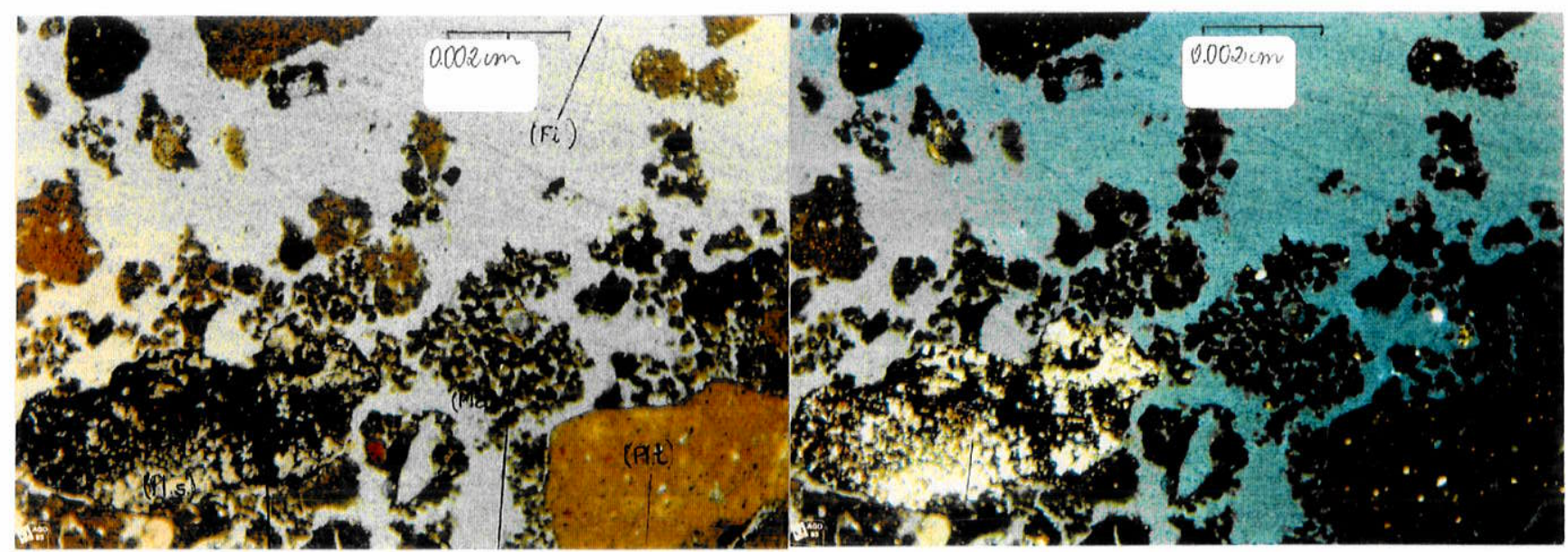

FOTO 10 - Fissura ramificada (Fi) com microagregados (M.a.) dispersos, mineral (Mi) com revestimento preto, plasma secundário (PI.s.) branco e plasma terciário (Pl.t.) alaranjado nas bordas (de solo natural de floresta). À esquerda luz natural e à direita nícois cruzados.

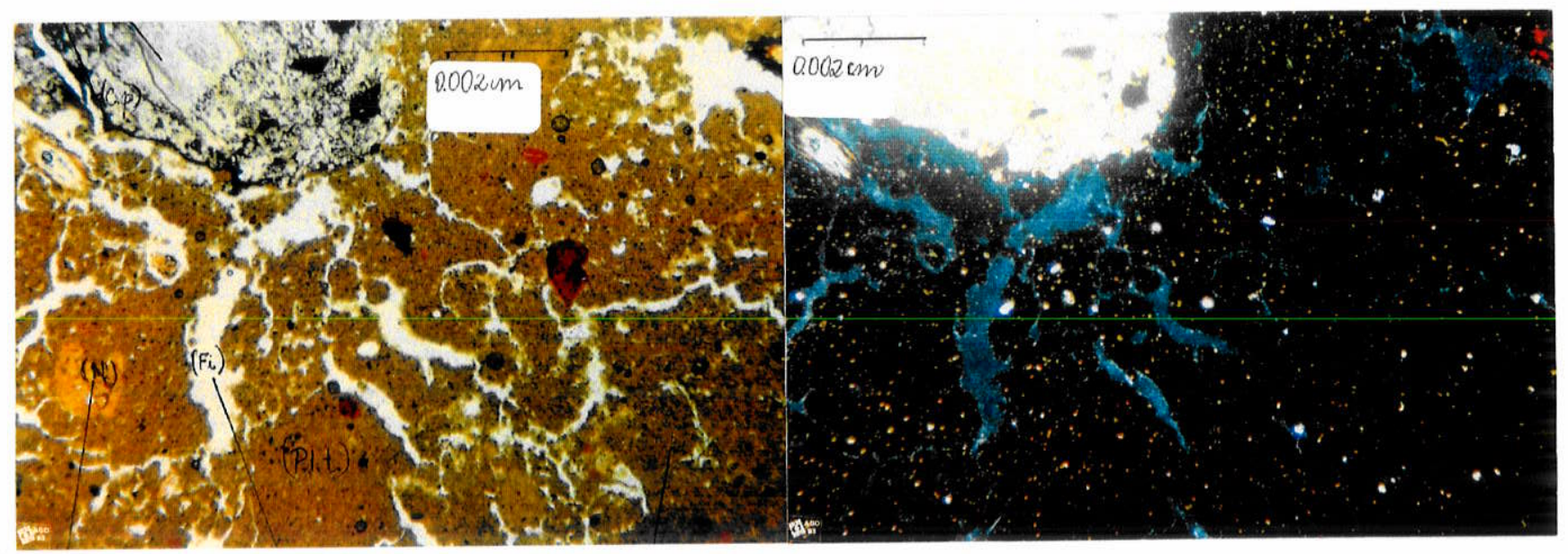

FOTO 11 - Fissuras em forma de rede, plasma terciário (PI.t.), mineral com cutăs pretos (C.p.), nódulos (N), restos de animais - estrutura aglomeroplámica (solo natural de floresta). À esquerda luz natural e à direita nícois cruzados. 
Entre 20 e $30 \mathrm{~cm}$ o plasma branco está muito atacado por material ferruginoso e por matéria orgânica ( $64 \%$ dos materiais da lâmina) cujas dimensões são da ordem de 2 a $3 \mathrm{~mm}$ de diâmetro, e o plasma amarelo alaranjado são porções fragmentadas das bordas do plasma branco, com dimensões da ordem de $0,3 \mathrm{~mm}$ e têm forma retangular. Estes materiais ocupam $35 \%$ do espaço total.

Entre as porções de plasmas coloridos e dispersos ao longo das fissuras mais largas aparecem nódulos ferruginosos, amarelos e brancos de dimensões de até $1 \mathrm{~mm}$ entre 0 e $30 \mathrm{~cm}$. como $1 \%$ dos materiais.

O sistema poral é formado por fissuras mais largas que separam os plasmas, da ordem de 4 a $5 \mathrm{~mm}$, e fissuras mais finas que recortam os plasmas coloridos internamente com largura entre 0,01 a $0,1 \mathrm{~mm}$ compondo uma rede (estrutura aglomeroplásmica).Esta microestruturação está presente em solos de alto grau de pedalidade (Brewer 1976) Estas feiçōes aparecem tanto nas lâminas cortadas verticalmente no perfil como nas cortadas horizontalmente.

Os materiais das partes mais profundas do perfil $(0,90$ a $1,40 \mathrm{~m})$ são predominantemente plasmas brancos (95\%) e estão gradualmente menos atacados por material ferruginoso e matéria orgânica. Os elementos têm dimensões da ordem de centímetros e são atravessados por fraturas retas preenchidas por revestimentos de cristais maiores. Nas bordas dos plasmas aparecem revestimentos ferruginosos que muito raramente se alargam e desprendem framnetos de plasma alaranjado (possivelmente um plasma terciário) que mais em superfície estão em maior quantidade distribuídos pelas fissuras, se desprendendo do plasma branco.

\section{b) Análise de Imagem}

A análise de imagem foi feita a partir da foto 10 (solo natural da floresta). Como esta é apenas uma parte muito pequena da lâmina, seria necessário analisar uma lâmina inteira para se ter idéia de uma pequena faixa do solo. Considerando que a evolução dos solos é um processo que se distribui por toda a superficie do terreno, em determinada posição do relevo, é possível adotar as feições analisadas como o aspecto geral da superfície deste solo.

Foram distintos por cores dois tipos de componentes, o plasma alaranjado com cor laranja-avermelhado, e os minerais brancos com cor azul (figura 17). Os vazios 


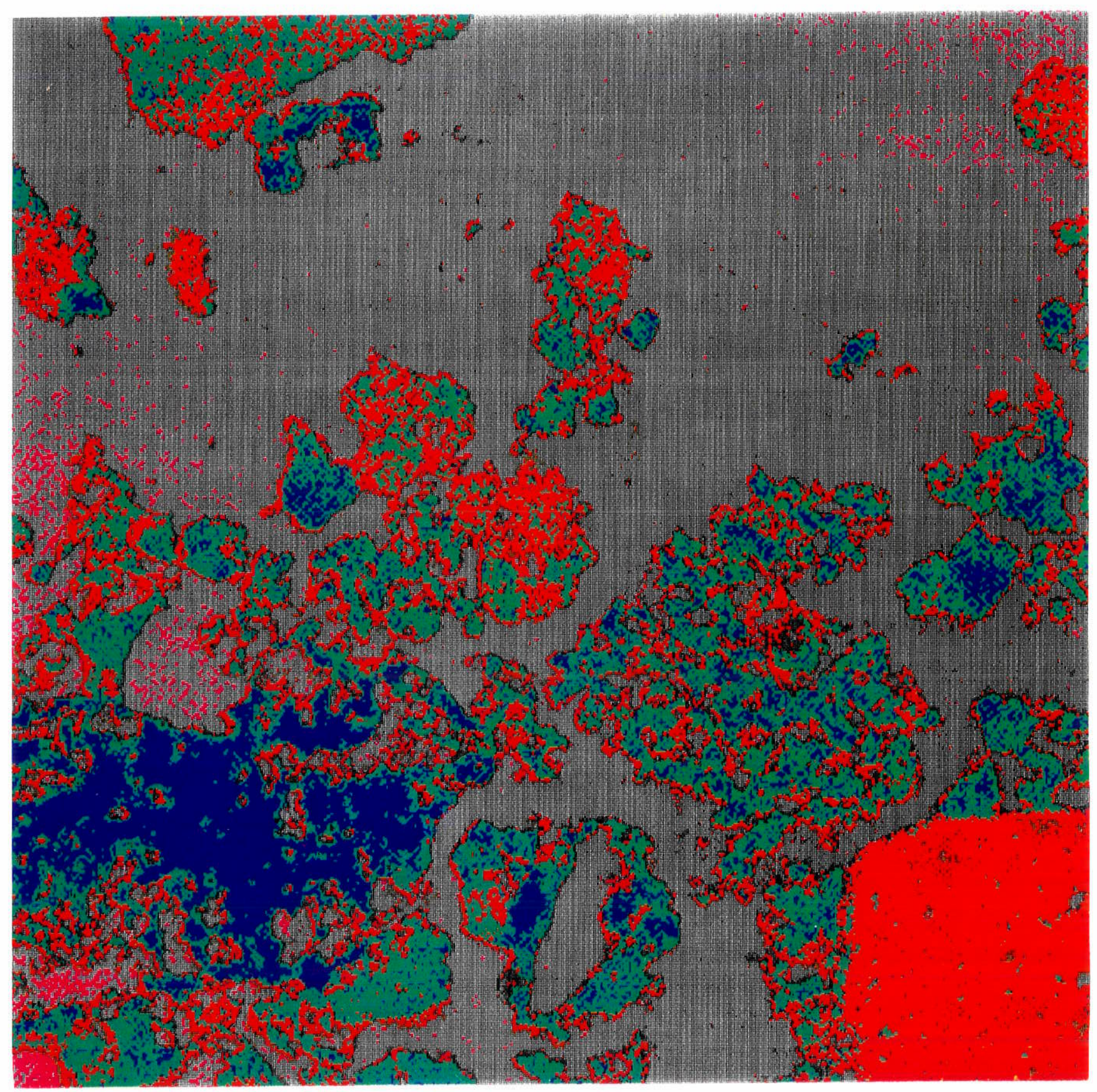

Figura 17. Imagem analisada com uso de cores pelo SITM 
foram coloridos com cinza. A mistura de laranja-avermelhado e azul resultou em verde que colore grande parte dos materiais microagregados.

A mistura de cores que aparece verde, pode levar a conclusão que os materiais que compöem os microagregados são fragmentos muito pequenos de ambos os componentes em estudo, o plasma e o mineral secundário, cimentados ou interligados. Considerando o papel da matéria orgânica na aglutinação de particulas minerais podese concluir que estas pedofeiçãos denominadas microagregados são organo-minerais que se desenvolvem em condições especiais. Numa estrutura onde grandes vazios permitem a circulação fácil de soluçōes e de particulas de matéria orgânica da classe dos colóides que participam na aglutinação de fragmentos ultramicroscópicos dos componentes básicos.

Os resultados de medida relativa das superfícies ocupadas pelos componentes básicos e pelos vazios mostraram que $60 \%$ desta imagem são de vazios e $40 \%$ são componente básicos. Da superficie ocupada pelos componentes básicos $30 \%$ é composta por um grande fragmento de plasma e por um grão de mineral bastante atacado por neoformações e $70 \%$ são microagregados. A partir desta análise pode-se verificar que os mecanismos de superfície, que incluen forte participação de porções muito finas de matéria orgânica, são responsáveis pelo desenvolvimento dos microagregados, cuja função pode éstar associada a nutrição das plantas uma vez que reúne partículas muito pequenas que mantém disponível ions e compostos para serem assimilados pelas raizes mais finas.

\section{c) Estudo microscópico dos solos novos}

Considerando os estudos anteriores realizados com solos naturais e sabendo de antemão que os solos novos são misturas de materiais de várias profundidades dos perfis naturais, o estudo dos solos novos comparou os materiais e fez observações $e$ descrições relativas às microestruturas existentes.

Os solos novos reabilitados a menos tempo ( 7 meses a 2 anos) apresentam mudanças de ordem estrutural primeiro porque são misturas de materiais de diferentes profundidades dos solos naturais e depois porque o preparo muda muito a disposição espacial dos materiais, principalmente das fissuras. Entre $0-7 \mathrm{~cm}$ predomina a mistura de plasma branco com bordas fraturadas (com 0,5 a $2 \mathrm{~mm}$ ) desprendendo partes alaranjadas e porções de plasma alaranjado e amarelado com várias dimensões, desde 0,1 até $0,5 \mathrm{~mm}$ bastante entrecortados por fissuras finas. As fissuras maiores 
têm $0,2 \mathrm{~mm}$ de largura e as menores $0,03 \mathrm{~mm}$. Aparecem nódulos de várias cores (brancos, amarelos, ferruginosos) de dimensões entre 0,1 e $1 \mathrm{~mm}$ entre os fragmentos de plasma alaranjado.

Num maior aumento foi possivel observar que muitas fissuras que estão nas bordas dos plasmas brancos foram revestidas por cutãns (tipo cristalária -foto 12) de material branco e por materiais ferrufinosos. Algumas fissuras foram deformadas e interrompidas e ocorreu também revestimentos das paredes (foto 13). Outra fissuras finas foram deformadas e apresentaram forma de cunha, além de terem sido preenchidas (foto 14).

Entre 10 e $15 \mathrm{~cm}$ o mesmo aspecto das estruturas, com plasmas secundários brancos fissurados nas bordas e desprendendo plasmas alaranjados e as fissuras mais finas também apresentam revestimentos. Em maior aumento é possivel notar que as fissuras de partes do plasma amarelo foram modificadas e revestidas (foto 15)

O solo novo de reabilitação mais antiga (Área 6) entre $0-10 \mathrm{~cm}$ apresenta os dois tipos de plasma, como nos solos naturais, mas o tamanho dos grãos ã superfície é maior, com as dimensões dos grãos que estão entre 20 e $40 \mathrm{~cm}$ nos solos naturais. Apresentam revestimento por material ferruginoso, penetrando na fissuras mais estreitas formando uma rede muito nítida. Em outras porções estas fissuras estão revestidas por material branco. As fissuras mais largas $(0,1 \mathrm{~mm})$ estão separando os grãos maiores e as fissuras mais finas são internas aos grãos, atravessando-os como uma rede mais fina. Em relação aos solos novos o que mais mudou foi a quantidade de fissuras que é menor e a largura que também diminuiu.

Entre 30 e $40 \mathrm{~cm}$ o plasma branco está com material ferruginoso mais disseminado em pontos menores que nos materiais das partes superiores. As porções são maiores $(0,5 \mathrm{~cm})$ e as fissuras internas mais largas, da ordem de $0,1 \mathrm{~mm}$ contêm fragmentos desprendidos de plasma alaranjado com forma retangular.

Em maior aumento observou-se a presença de cristais brancos bem desenvolvidos distribuídos dentro de um poro preenchido por material preto (foto 16) e dentro do plasma branco as fissuras menores apresentam forma de cunhas e estão preenchidas totalmente por cristalárias (foto 17). 


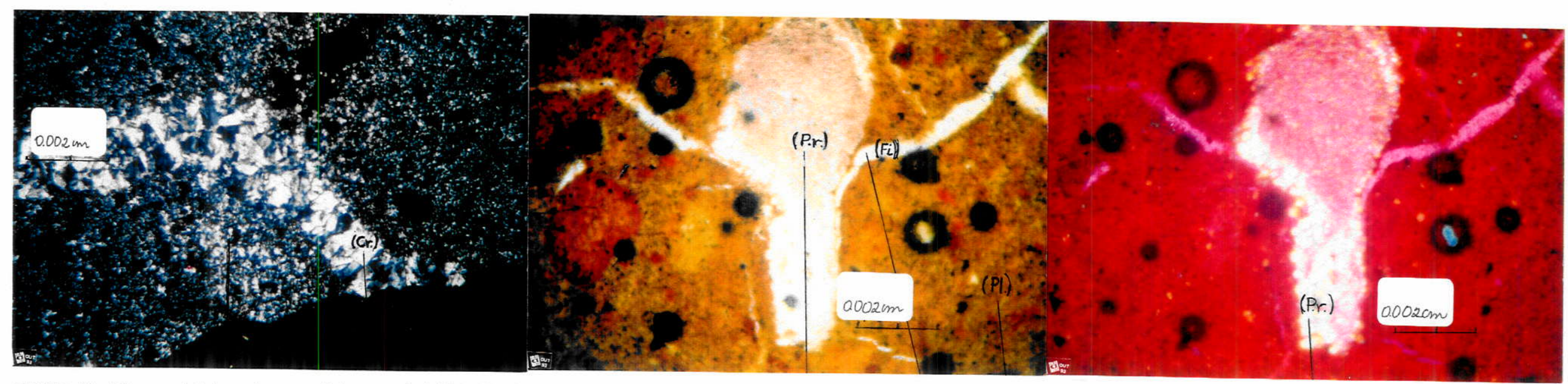

FOTO 12 - Fissura totalmente revestida por cristalária $(\mathrm{Cr}$ ) em plasma alaranjado (solo novo com 2 anos de reabilitado Área 2) à luz polarizada.

FOTO 13 - Poro deformado parcialmente revestido (P.r.), fissuras (Fi), plasma alaranjado (PI.). À esquerda luz natural, à direita nícois cruzados e cunha de gipso (solo novo da Área 5 após 2 anos de reabilitaçăo).

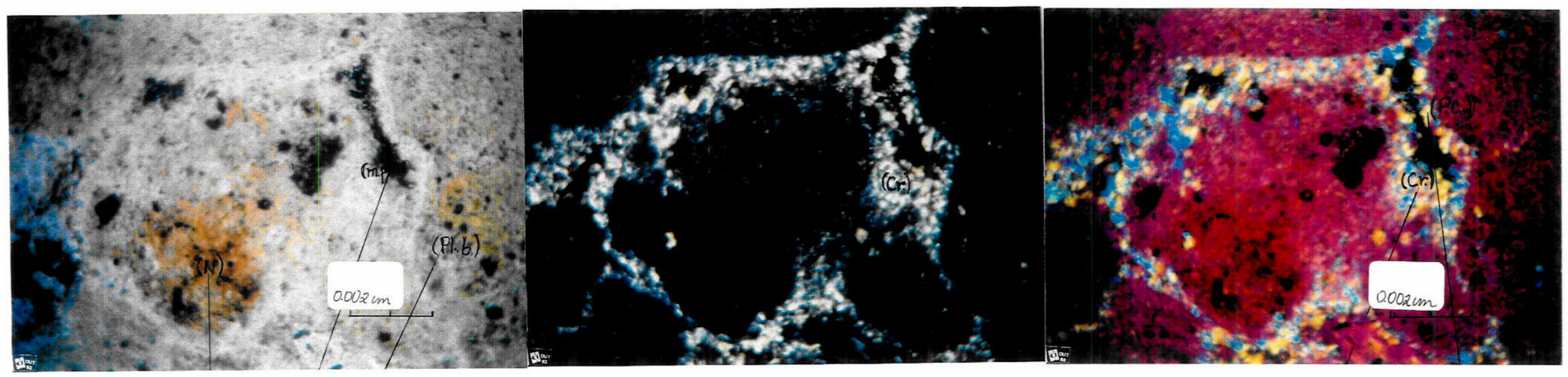

FOTO 14 - Plasma branco (PI.) com nódulos (N), com poros em forma de cuna (P. revestido por cristalária $(\mathrm{Cr})$ e por material preto (m.p.). A esquerda luz natural, no centro nícois cruzados e à direita com cunha de gipso (solo novo da Área 8 revegetada há 2 anos) 


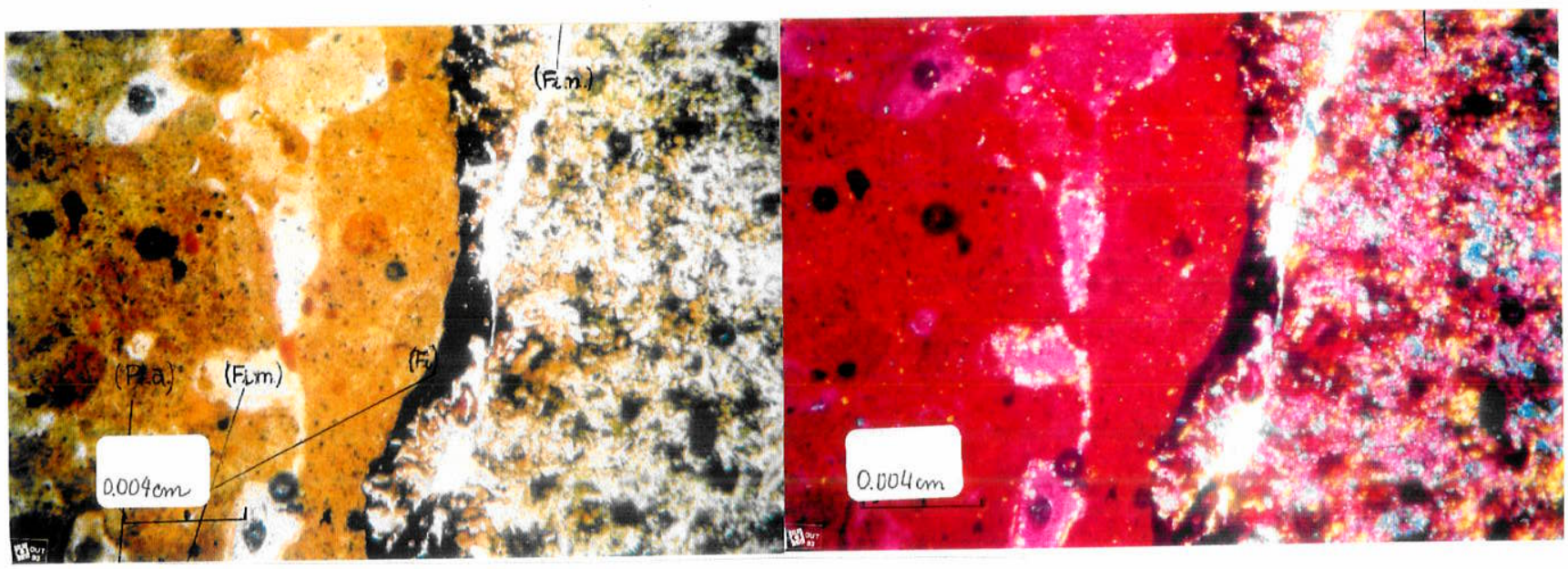

FOTO 15 - Plasma amarelo (PI.a.) com fissuras modificadas (Fi.m.) e plasma branco (PI.b.) com uma nova fissura (Fi.n.) separados por fissura preenchida por material ferruginoso ( $\mathrm{Fi}$ ) (em solo novo da Área 2 reabilitada há 3 anos). À esquerda luz natural e à direita nícois cruzados.

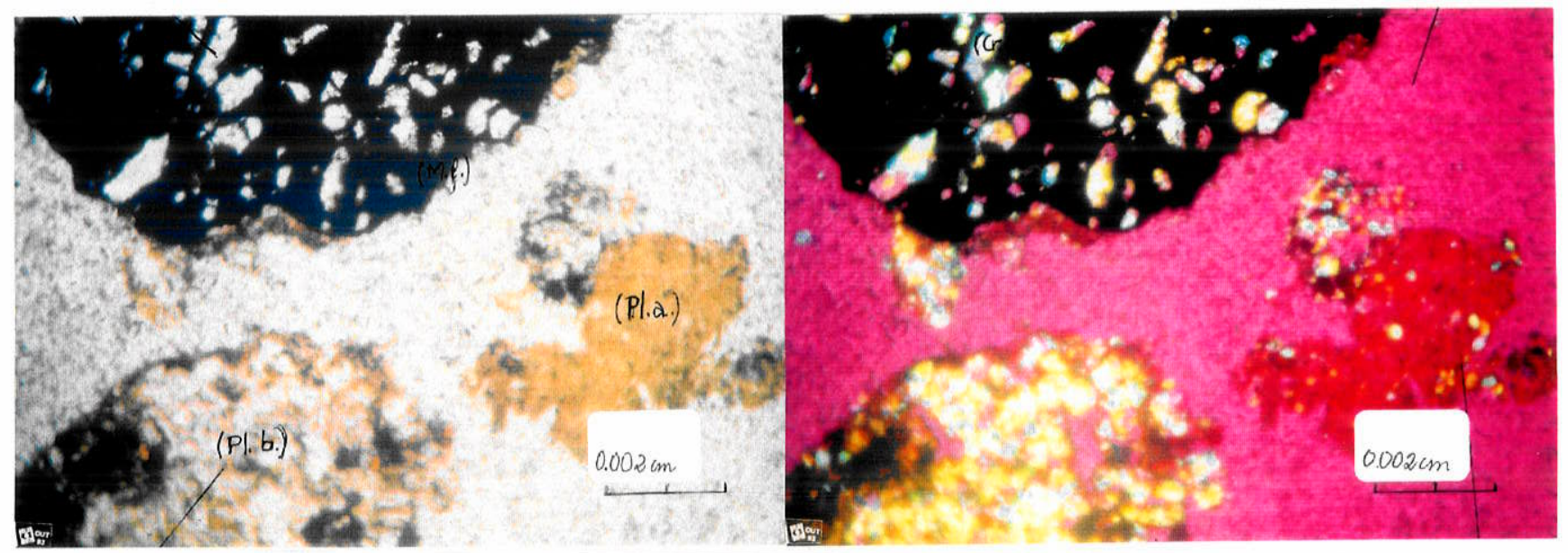

FOTO 16 - Plasma branco (PI.b.) com plasma alaranjado (pl.a.) nas bordas e cristais bem desenvolvidos de gibbsita (Cr.g.) dentro de material ferruginoso (M.f.) (solo novo da Área 4 reabilitada há 6 anos). À esquerda luz natural e à direita nícois cruzados.

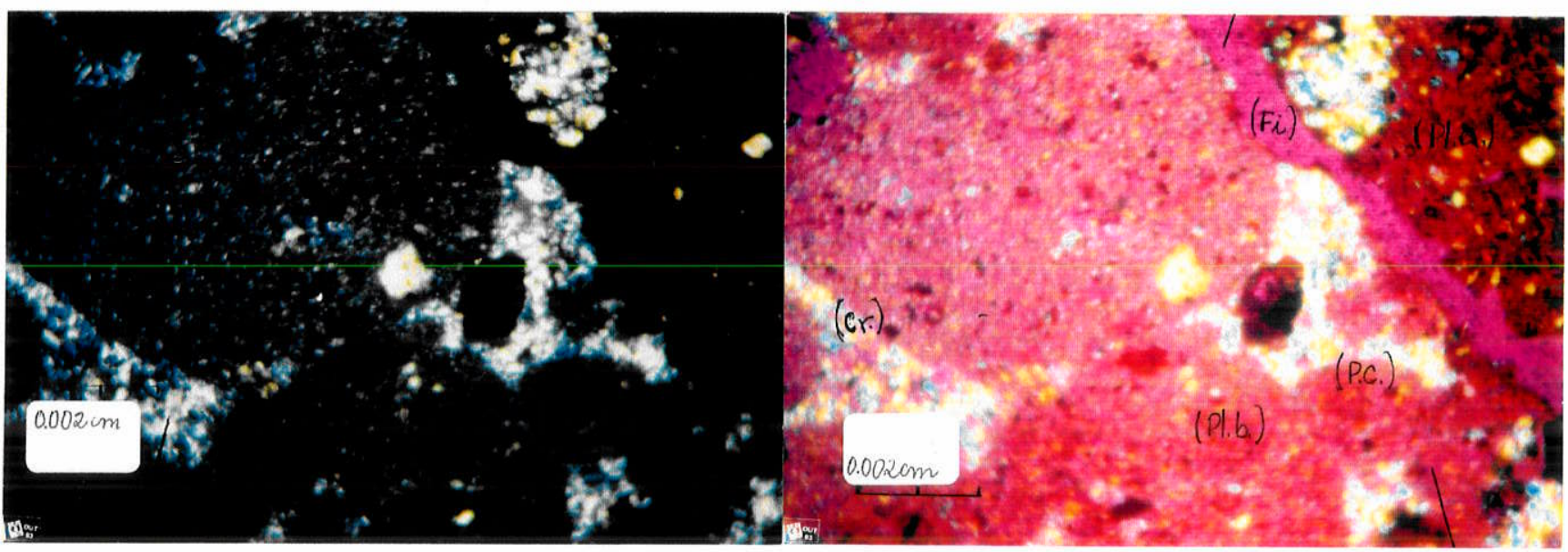

Foto 17 - Plasma branco (PI.b.) com poros em forma de cunha (P.c.) revestidos com cristalária $(\mathrm{Cr})$ e plasma alaranjado (Pl.a.) separados por fissural natural (Fi) (solo novo da Área 8, revegetado há 2 anos) À esquerda nícois cruzados e à direita com cunha de gipso. 


\subsubsection{OBSERVAÇÖES E ANÁLISES AO MEV - EDS}

Os materiais usados no estudo ao MEV fazem parte dos agregados dos solos naturais e do substrato resultante das áreas pós-mineradas (a aproximadamente $15 \mathrm{~m}$ de profundidade do manto). Estes agregados estão participando na reabilitação associados ao "top-soil" distribuído sobre as áreas. Além de observar e fotografar a estruturação, considerando as ampliações do equipamento, foi feita análise química qualitativa dos componentes, por EDS, tanto dos agregados (foto 18) como do substrato (foto19).

Os agregados dos solos naturais mostraram grande porosidade, com placas de caulinita e grãos de gibbsita justapostos, e alguns cristais de goethita num arranjo espacial mostrado na foto 20 . O espectro EDS-1 da figura 18 mostra a composição química qualitativa típica deste material, com presença de Al, si e Fe.

Os fragmentos do substrato minerado (alterita estéril) mostraram a presença dos minerais secundários com maiores dimensões que nos agregados dos solos naturais (caulinita em placas hexagonais ou pseudohexagonais, gibbsita em cristais prismáticos bem formados e goethita em cristais alongados) e num arranjo menos poroso que nos solos (fotos 21 e 22). O espectro EDS-2 (figura 18) mostra a: composição química qualitativa de úm ponto central, sobre vários cristais justapostos e o espectro EDS-3 refere-se à composição química qualitativa em uma linha cortando um destes fragmentos do substrato; estão presentes, além de $\mathrm{Al}$, Si e Fe (e traços de Ti), elementos químicos que mostram a influência de minerais primários ainda não totalmente desestabilizados: $\mathrm{Ke} \mathrm{Ca}$.

\subsubsection{ESTUDOS MICROGEOQUÍMICOS À MICROSSONDA ELETRÔNICA}

O estudo foi feito em lâmina de solos naturais e novos sobre pontos selecionados e relacionados com a evolução pedogenética das feições e dos materiais. Os resultados das análises da lâmina do solo natural de campo cerrado (entre 7-10cm) está apresentado no Diagrama M.1 da figura 19. Foram escolhidos 17 pontos sobre a lâmina, 6 sobre plasma amarelo-alaranjado, 2 sobre plasma amarelomarrom, 4 sobre minerais brancos, 4 sobre pontos pretos e 1 sobre ponto cinza (tabela 15). 


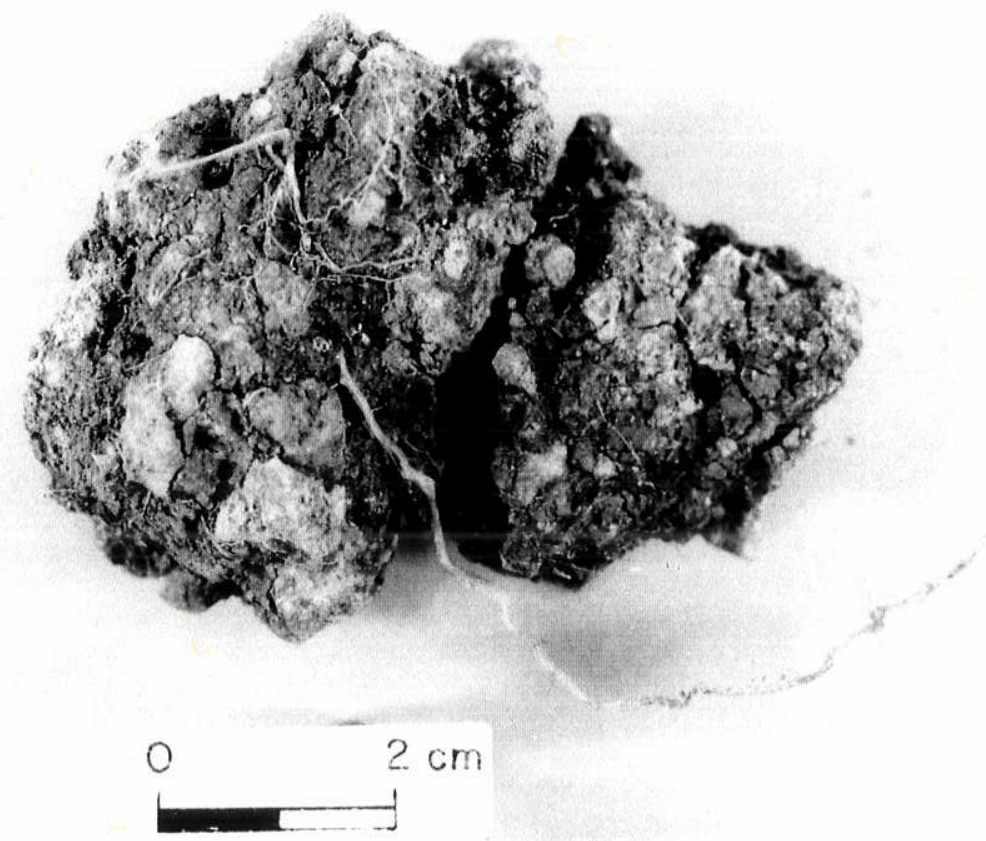

Foto 18 - Agregado do solo natural de floresta

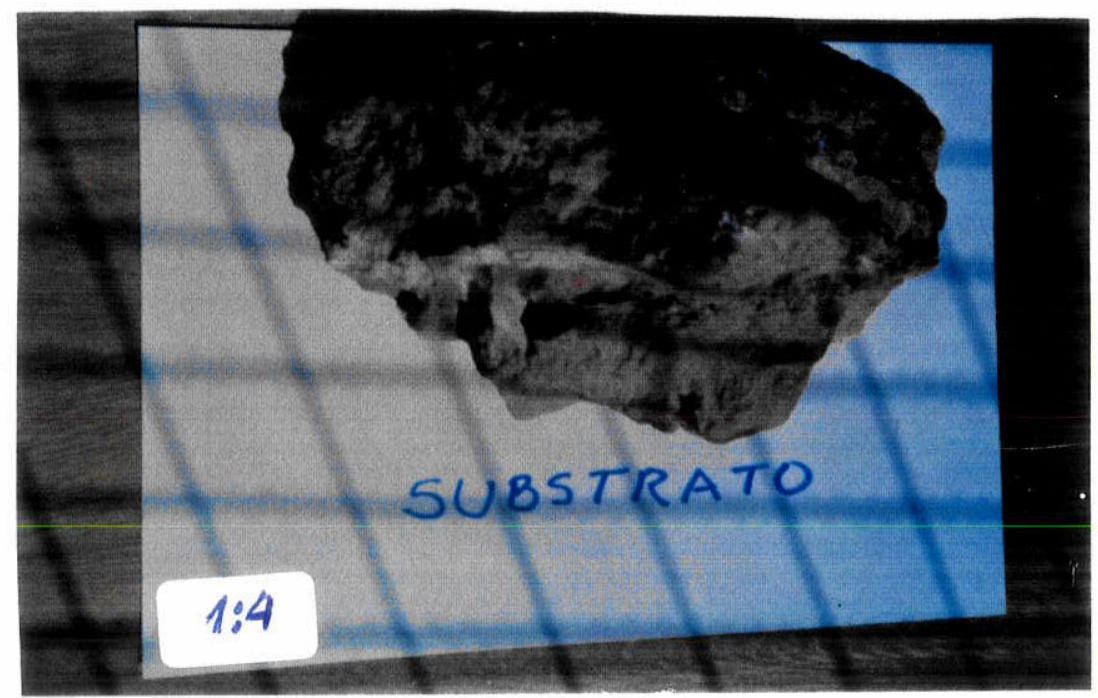

Foto 19 - Bloco do substrato pós-minerado 



Foto 21 - Imagem do MEV fragmento do bloco de substrato



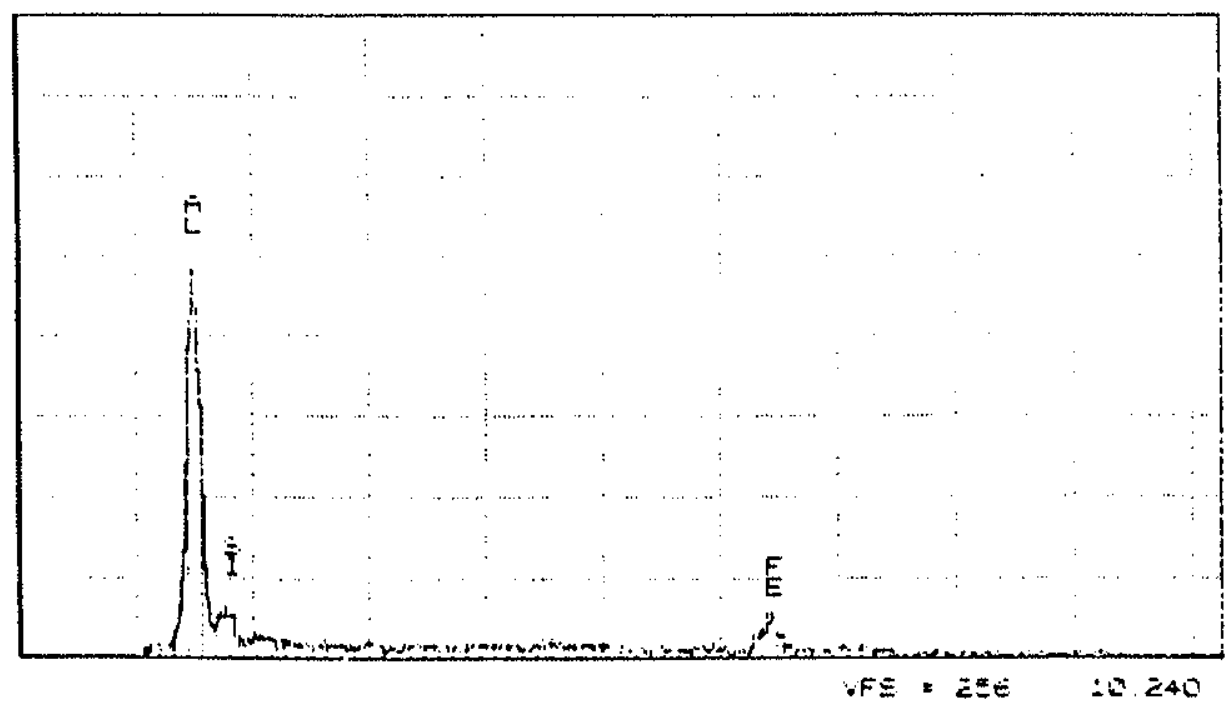

ESPECTRO EDS-1

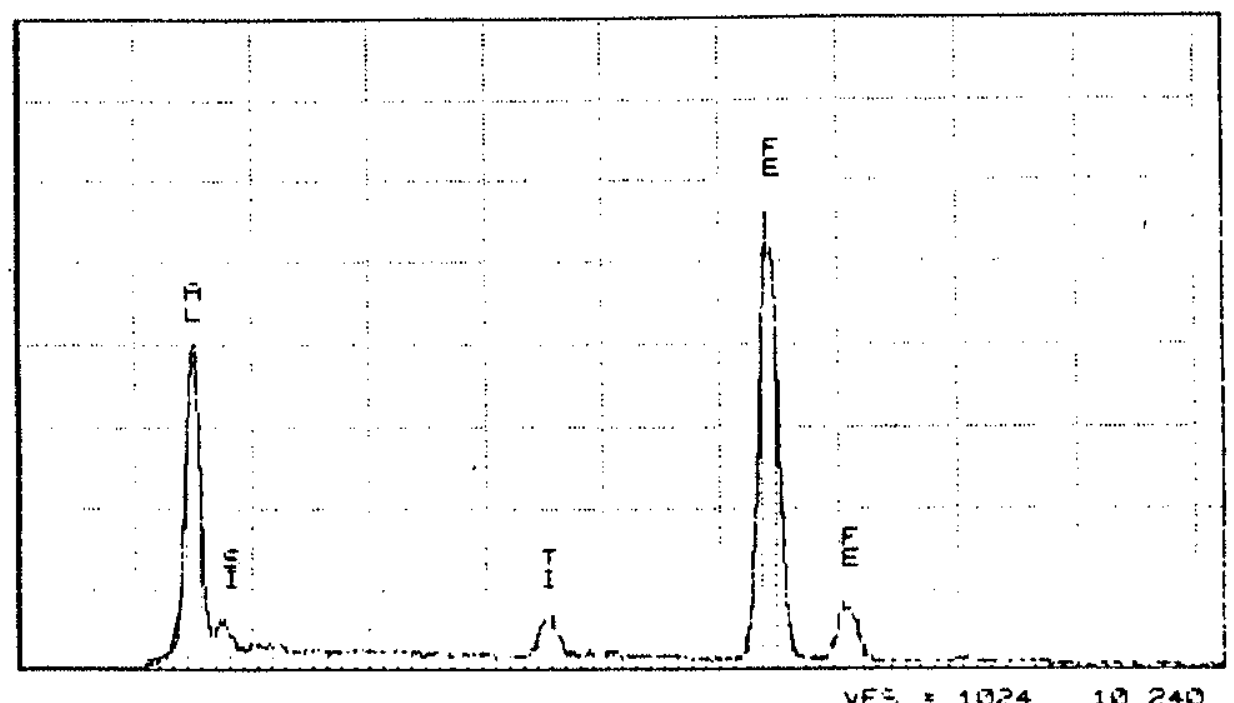

ESPECTRO EDS-2

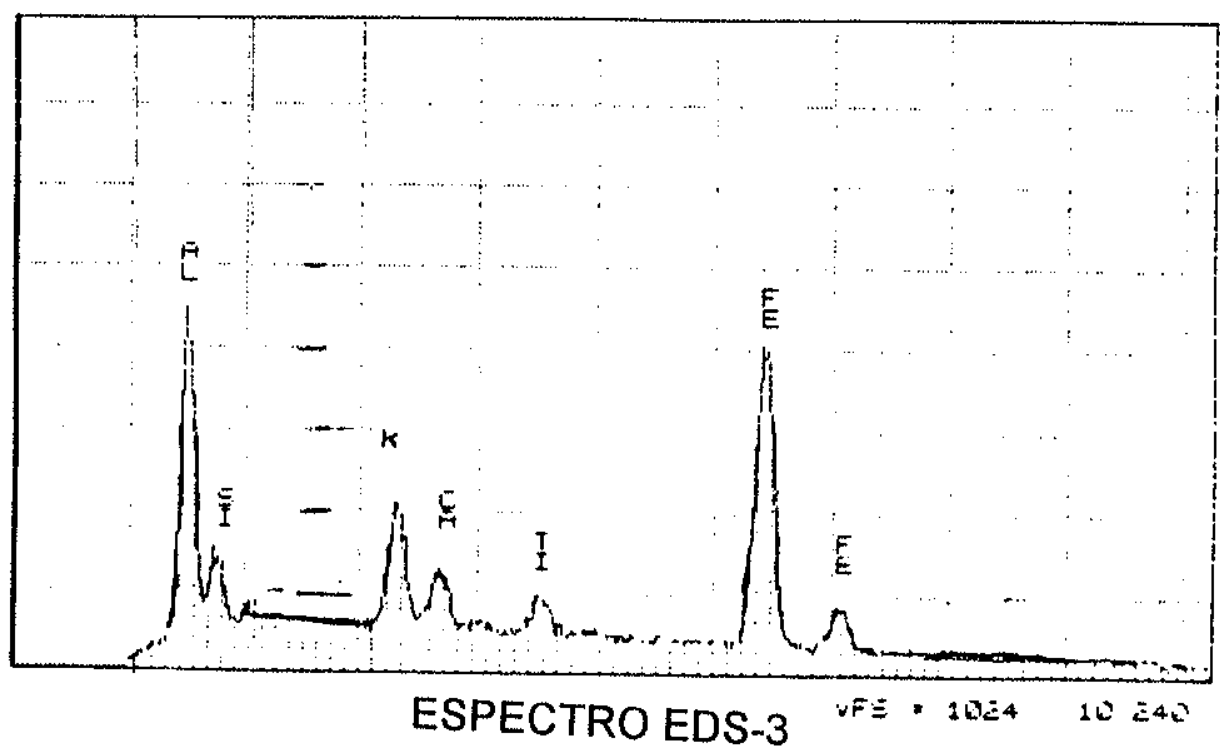

Figura 18 - Espectros EDS: Espectro EDS-1 - análise de partículas arredondadas (imagem da foto 20); Espectro EDS-2 - análise de cristal alongado (imagem do substrato placas, cristais alongados e romboédricos); Espectro EDS - 3 análise do substrato através de uma linha horizontal no centro da foto 22 


\begin{tabular}{|c|c|c|c|c|c|c|c|}
\hline \multicolumn{7}{|c|}{ Lâmina 1 Amostra de solo indeformado do Campo Cerrado } & \\
\hline & Área 1 solo natural com vegetação típica & & & \\
\hline & Profundidade 7 a 10cm & & & & \\
\hline & & & & & & & \\
\hline Ponto & SiO2 & Al203 & Fe203 & Si & Al & Fe & 0 \\
\hline 1 & 0.120 & 68.465 & 0.480 & 0.059 & 39.787 & 0.178 & 59.976 \\
\hline 2 & 1.068 & 64.991 & 3.275 & 0.535 & 38.371 & 1.235 & 59.860 \\
\hline 3 & 0.374 & 26.968 & 33.290 & 0.287 & 24.320 & 19.169 & 56.224 \\
\hline 4 & 44.356 & 38.304 & 0.000 & 18.036 & 18.357 & 0.000 & 63.607 \\
\hline 5 & 61.838 & 16.493 & 0.487 & 26.332 & 8.277 & 0.156 & 65.235 \\
\hline 6 & 12.739 & 14.828 & 2.659 & 14.828 & 20.342 & 2.329 & 62.500 \\
\hline 7 & 2.002 & 48.101 & 23.640 & 1.093 & 30.925 & 9.705 & 58.278 \\
\hline 8 & 1.874 & 55.143 & 1.282 & 1.102 & 38.224 & 0.567 & 60.107 \\
\hline 9 & 0.644 & 14.681 & 48.571 & 0.544 & 14.627 & 30.901 & 53.929 \\
\hline 10 & 0.130 & 59.648 & 0.080 & 0.074 & 39.883 & 0.034 & 60.008 \\
\hline 11 & 0.359 & 46.391 & 12.162 & 0.230 & 35.033 & 5.865 & 58.873 \\
\hline 12 & 0.729 & 65.361 & 2.160 & 0.369 & 38.901 & 0.821 & 59.901 \\
\hline 13 & 0.071 & 38.943 & 0.962 & 0.061 & 39.430 & 0.622 & 59.888 \\
\hline 14 & 0.265 & 18.662 & 20.893 & 0.305 & 25.214 & 18.024 & 56.456 \\
\hline 15 & 0.212 & 56.964 & 1.042 & 0.124 & 39.482 & 0.461 & 59.993 \\
\hline 16 & 0.244 & 64.431 & 0.080 & 0.128 & 39.821 & 0.033 & 60.019 \\
\hline 17 & 0.738 & 9.642 & 42.791 & 0.778 & 11.957 & 33.887 & 53.378 \\
\hline $1,3,4,9,13$ pontos amarelos da lâmina & & & & \\
\hline $2,6,10,14,15$ pontos pretos da lâmina & & & & \\
\hline $5,12,17,18$ pontos branco da lâmina & & & & \\
\hline 8,16 pontos marrom & & & & & & \\
\hline 11 ponto laranja & & & & & & \\
\hline 7 ponto cinza & & & & & & \\
\hline
\end{tabular}

Tabela 14. Resultados das análises à M.E. sobre amostras do solo natural de campo cerrado Área 1

Os resultados da composição química não corresponde às diferentes cores dos minerais ou plasmas porque a matéria orgânica pode mascarar os materiais microcristalinos. Assim, nos solos naturais de campo cerrado, entre 7 e $10 \mathrm{~cm}$, as composições com maiores teores de sílica encontradas estavam em dois plasmas de cor branca e um em cor cinza, e um material muito rico em silica tinha cor preta (matéria orgânica). As composições de altos teores de alumínio foram encontradas em 6 pontos de plasma amarelo ou marrom, 2 pontos em material preto e um em plasma branco. As composições com altos teores de ferro estavam em um ponto sobre plasma amarelo-avermelhado e em dois em plasma branco. Com a presença de matéria orgânica distribuída sobre os materiais dos solos os pontos pretos apresentam a 
composição química do material abaixo. Considerando a linha da caulinita no diagrama triangular, dois pontos da lâmina referem-se a plasmas com esta composição. (Diagrama M.1, Figura 19).

O Diagrama M.2 da figura 19 apresenta os resultados de outro lâmina do mesmo solo natural à profundidade entre $33 \mathrm{e} 40 \mathrm{~cm}$ (tabela 15). Foram analisados apenas 4 pontos porque os materiais são dois plasmas, um branco e outro marromavermelhado. Os três pontos sobre o plasma branco apresentaram composição com predominância de alumínio e um ponto em plasma marrom-avermelhado apresentou composição com predominância de alumínio e teor importante de ferro.



Tabela 15. Resultados das análises à M.E. sobre amostra de solo natural de campo cerrado

Nas lâminas de solos novos, os revestimentos e principalmente as cristalárias foram escolhidas e comparadas com a composição dos plasmas próximos.

O Diagrama M.3 da figura 20 apresenta os resultados das análises de 15 pontos selecionados numa lâmina de solo novo do Retiro Branco I amostrado emtre 7$10 \mathrm{~cm}$, após 6 anos de reabilitação. Três pontos indicaram composição predominante de sílica, sendo um ponto em plasma branco e um em plasma amarelo. Sete pontos indicaram ser sobre plasma aluminoso com altos teores de ferro, dois de cor amarela, 3 de cor branca, um preto e outro cinza. Cinco pontos indicaram material rico em alumínio, dois de cor branca, dois de cor preta e um laranja. Considerando a linha da caulinita no diagrama triangular, dois pontos estão próximos ou seja dois pontos indicam material caulinítico. 


\begin{tabular}{|c|c|c|c|c|c|c|c|}
\hline & Lâmina & Amostra & olo do & mpo Reti & Branco & & \\
\hline & Area 2 So & revegeta & o há 3 an & & & & \\
\hline & Profundid & de 0 a $7 \mathrm{cr}$ & & & & & \\
\hline & $\mathrm{SiO} 2$ & $\mathrm{~A} 1203$ & $\mathrm{Fe} 2 \mathrm{O3}$ & $\overline{S i}$ & $\mathrm{Al}$ & $\mathrm{Fe}$ & 0 \\
\hline 1 & 1.632 & 10.386 & 43.232 & 1.623 & 12.172 & 32.350 & 55.855 \\
\hline 2 & 1.074 & 8.368 & 38.635 & 1.249 & 11.465 & 33.795 & 53.491 \\
\hline 3 & 0.028 & 0.019 & 0.081 & 10.775 & 8.697 & 22.965 & 57.562 \\
\hline 4 & 1.159 & 8.219 & 34.180 & 1.465 & 12.240 & 32.501 & 53.793 \\
\hline 5 & 2.079 & 10.345 & 43.070 & 2.061 & 12.088 & 31.798 & 54.053 \\
\hline 6 & 2.429 & 0.905 & 0.567 & 22.665 & 9.693 & 3.886 & 63.756 \\
\hline 7 & 12.795 & 25.502 & 8.684 & 10.107 & 23.741 & 5.162 & 60.989 \\
\hline 8 & 1.239 & 61.463 & 0.480 & 0.668 & 39.043 & 0.195 & 60.095 \\
\hline 9 & 1.149 & 9.689 & 36.276 & 1.327 & 13.188 & 31.525 & 53.960 \\
\hline 10 & 0.336 & 59.870 & 0.320 & 0.189 & 39.665 & 0.135 & 60.011 \\
\hline 11 & 1.356 & 59.674 & 0.880 & 0.749 & 38.809 & 1.765 & 60.077 \\
\hline 12 & 1.356 & 53.161 & 3.823 & 0.138 & 38.422 & 1.765 & 59.675 \\
\hline 13 & 0.255 & 53.161 & 3.823 & 0.138 & 38.422 & 1.765 & 59.675 \\
\hline 14 & 1.649 & 12.451 & 30.387 & 1.888 & 16.796 & 26.173 & 55.143 \\
\hline$\frac{1,2,15 p}{3,6,9,10}$ & $\frac{\text { os amarelos }}{\text { pontos bran }}$ & $\frac{\text { a lâmina }}{\text { ss na lâm }}$ & & & & & \\
\hline 4,8 pont & inza da lâm & & & & & & \\
\hline $5,11,12$ & os pretos de & âmina & & & & & \\
\hline $7.13 \mathrm{pon}$ & Laranja da la & nina & & & & & \\
\hline
\end{tabular}

Tabela 16. Resultados das análisesà M.E sobre amostras do solo novo da Área 2 .

O Diagrama M.4 da figura 20 apresenta estudo de 32 pontos sobre a lâmina de solo novo da Área 6 entre $6-15 \mathrm{~cm}$. Considerando a linha da caulinita no diagrama triangular. este mineral foi identificado em 20 pontos dos quais 5 pontos em plasma branco e $4 \mathrm{em}$ cristalárias, $7 \mathrm{em}$ plasma amarelo avermelhado mais marrom, $2 \mathrm{em}$ material preto 1 em plasma cinza e um na borda de um material azul. Os materiais ricos en alumínio foram indentificados em 10 pontos, $6 \mathrm{em}$ plasmas brancos, $2 \mathrm{em}$ plasma amarelo, um em mineral azul e um em ponto preto. A goethita foi detectada em apenas um ponto. 

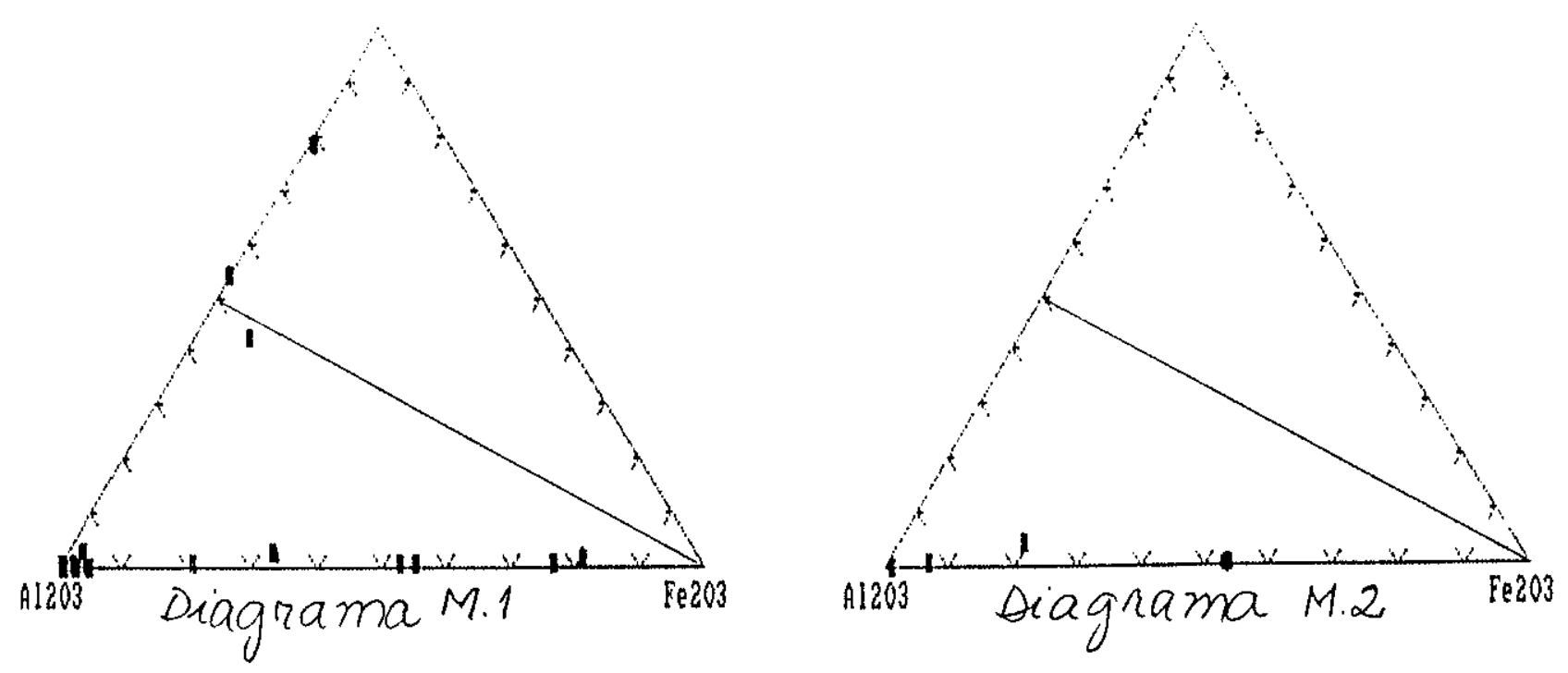

Flgura 19. Dlagramas da Composição Mineralóglca: Dlagrama M.1 - 17 pontos em lâmina de solo natural da Área 1, profundidade $7-10 \mathrm{~cm}$; Dlagrama $M .2-4$ pontos de lâmina de solo natural da Área 1, profundldade $35-40 \mathrm{~cm}$.
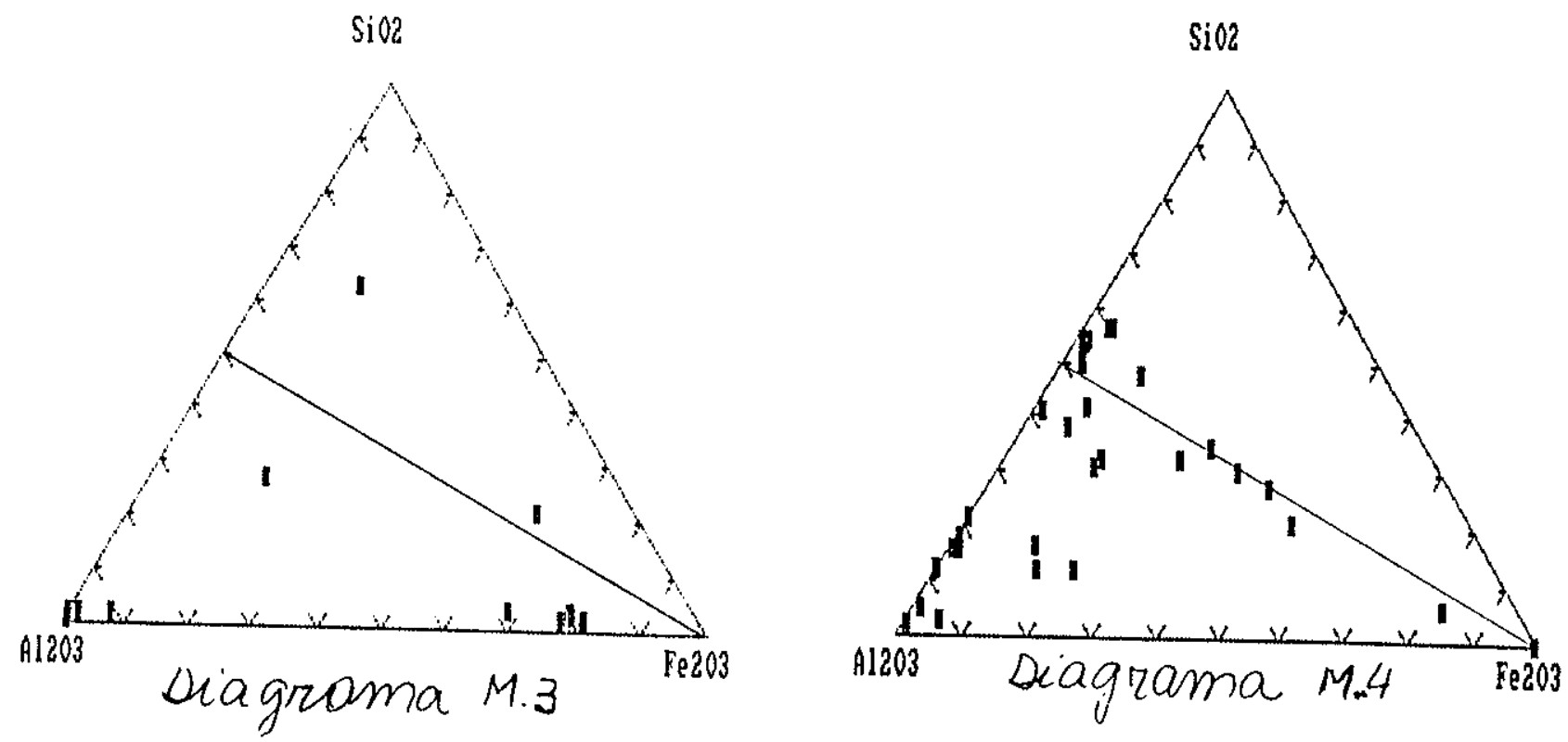

Flgura 20. Dlagramas da Composição Mineralógica: Dlagrama M.3 - 15 pontos em lâmina de solo novo da Área 2, profundidade $7-10 \mathrm{~cm}$; Dlagrama M.4 - 32 pontos em lâmina de solo novo da Área 6 , profundldade $6-15 \mathrm{~cm}$. 


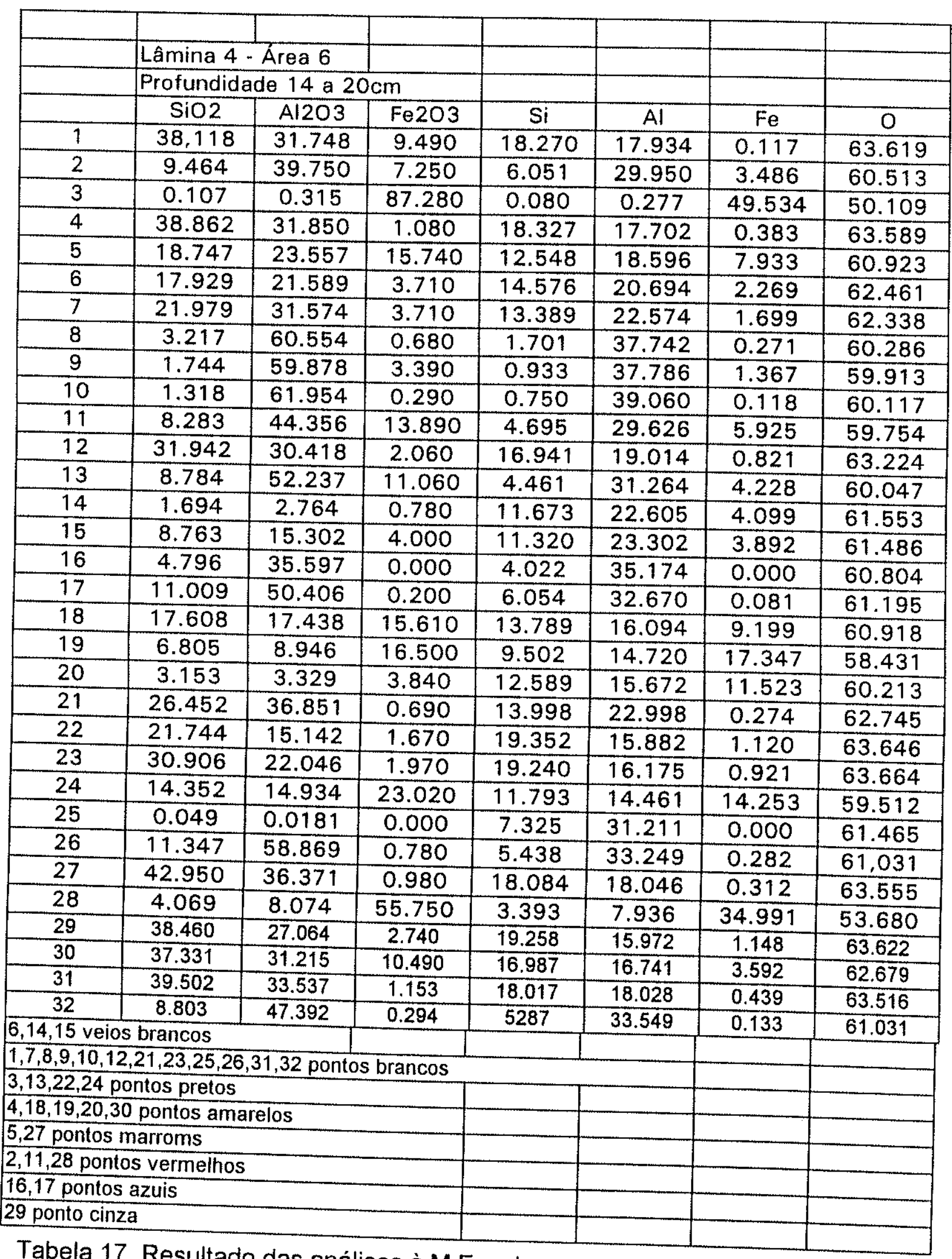

Tabela 17. Resultado das análises à M.E. sobre amostras de solo novo da Área 4

O Diagramam M.5 da figura 21 apresenta estudo de 11 pontos sobre os materias da lâmina de solo novo do Campo de Santa Rosália na parte revegetada, 
entre $0-10 \mathrm{~cm}$ (tabela 18). A composição predominante de alumínio foi encontrada em 9 pontos, 4 em plasma branco, 2 em plasma laranja, $2 \mathrm{em}$ material preto e um em plasma cinza. Dois pontos são ricos em ferro, um em plasma amarelo outro em plasma branco.

O Diagrama M.6 da figura 21 apresenta estudo de 11 pontos sobre os materiais da lâmina de solo novo do Campo de Santa Rosáila na área-piloto, entre $0-10 \mathrm{~cm}$ (tabela 19). A composição predominante de alumínio foi identificada em 8 pontos, $3 \mathrm{em}$ plasma branco, $2 \mathrm{em}$ materiais pretos, 2 em plasma laranja e em um material azul. A composição química rica em ferro foi identificada em dois pontos, um em plasma laranja e outro em plasma vermelho.

O Diagrama M.7 da figura 21 apresenta os resultados de análise de 3 pontos sobre materiais da lâmina do solo novo do Campo de Santa Rosália, entre $40-46 \mathrm{~cm}$ (tabela 20). A composição química com predominância em alumínio foi indentificada em dois pontos de plasma branco e composição rica em ferro em um ponto preto.

\begin{tabular}{|c|c|c|c|c|c|c|c|}
\hline & & & & & & & \\
\hline & Lâmina 5 & Amostra d & n. & ormado & . & ta Rosáli & \\
\hline & Área 8 so & novo rev & getado co & mudas & gramíneas & ha 2 anos & \\
\hline & Profundide & de 0 a $10 c$ & & & & & \\
\hline Ponto & & & & & & & \\
\hline & & A 1203 & $\mathrm{Fe} 2 \mathrm{O} 3$ & $\mathrm{Si}$ & $\mathrm{Al}$ & $\mathrm{Fe}$ & 0 \\
\hline 1 & 0.385 & 58.003 & 0.640 & 0.222 & 39.511 & 0.278 & 59.989 \\
\hline 2 & 8.228 & 38.301 & 6.855 & 5.565 & 30.531 & 3.489 & 60.415 \\
\hline 3 & 0.304 & 59.234 & 0.000 & 0.173 & 39.792 & 0.000 & 60.035 \\
\hline 4 & 0.982 & 75.604 & 0.951 & 0.432 & 39.227 & 0.319 & 60.023 \\
\hline 5 & 1.799 & 17.262 & 48.854 & 1.386 & 15.675 & 28.327 & 54.612 \\
\hline 6 & 1.350 & 13.855 & 49.101 & 1.136 & 13.748 & 31.110 & 54.005 \\
\hline 7 & 2.809 & 38.729 & 3.833 & 2.189 & 35.574 & 2.249 & 59.988 \\
\hline 8 & 0.173 & 57.709 & 0.720 & 0.101 & 39.626 & 0.316 & 59.957 \\
\hline 9 & 0.240 & 58.293 & 0.962 & 0.137 & 39.502 & 0.416 & 59.944 \\
\hline 10 & 0.329 & 68.208 & 1.840 & 0.161 & 35.265 & 0.676 & 59.897 \\
\hline 11 & 0.488 & 53.148 & 11.064 & 0.279 & 35.853 & 4.766 & 59.103 \\
\hline $1,2,6,7,1$ & pontos br & ncos & & & & & \\
\hline 3,8 ponto & pretos & & & & & & \\
\hline 4,9 ponto & laranja & & & & & & \\
\hline 11 cinza & & & & & & & \\
\hline
\end{tabular}

Tabela 18. Resultado das análises à M.E. dos materiais do solo da Área 8 revegetada. 

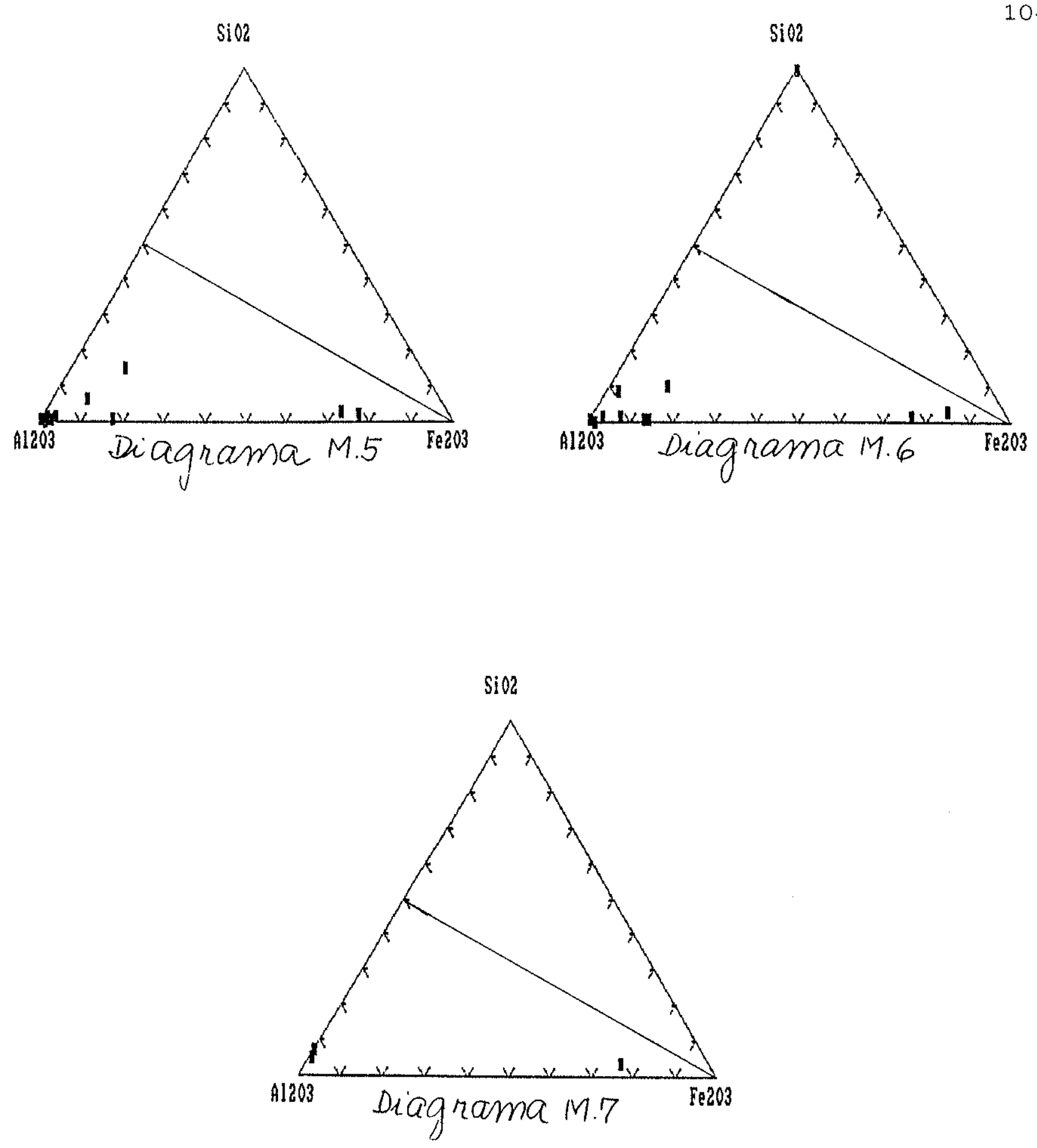

Figura 21. Diagramas da Composição Mineralógica: Diagrama M5 - 12 pontos em lâmina de solo novo da Área 8 revegetada, profunidade 2-10cm; Diagrama M6 - 11 pontos em lâmina de solo novo da Área $8 \mathrm{~s} /$ vegetação, profundidade $2-10 \mathrm{~cm}$; Diagrama M7 - 3 pontos da Área 8 revegetada, profundidade $43 \mathrm{~cm}$. 


\begin{tabular}{|c|c|c|c|c|c|c|c|}
\hline & \multicolumn{7}{|c|}{ Lâmina 6 Amostra de solo indeformado do Campo Santa Rosália } \\
\hline & \multicolumn{7}{|c|}{\begin{tabular}{|l|l|l|} 
Área 8 solo novo sem revegetaçao, área-piloto & \\
\end{tabular}} \\
\hline & \multicolumn{3}{|c|}{ Profundidade 0 a $10 \mathrm{~cm}$} & & & & \\
\hline & & & & & & & \\
\hline Ponto & $\mathrm{SiO} 2$ & $\mathrm{~A} 1203$ & $\mathrm{Fe} 203$ & Si & $\mathrm{Al}$ & $\mathrm{Fe}$ & $\mathrm{O}$ \\
\hline 1 & 0.362 & 63.609 & 0.087 & 0.191 & 39.740 & 0.039 & 60.030 \\
\hline 2 & 6.495 & 48.481 & 8.763 & 3.700 & 32.554 & 3.757 & 59.989 \\
\hline 3 & 1.803 & 8.172 & 50.531 & 1.708 & 9.126 & 36.030 & 53.136 \\
\hline 4 & 5.603 & 55.453 & 1.555 & 3.070 & 35.803 & 0.641 & 60.486 \\
\hline 5 & 0.237 & 70.064 & 1.069 & 0.113 & 39.556 & 0.385 & 59.946 \\
\hline 6 & 77.821 & 0.166 & 0.197 & 33.221 & 0.084 & 0.064 & 66.631 \\
\hline 7 & 0.943 & 65.809 & 1.942 & 0.473 & 38.847 & 0.732 & 59.948 \\
\hline 8 & 0.255 & 47.476 & 7.152 & 0.169 & 36.954 & 3.555 & 59.323 \\
\hline 9 & 0.620 & 14.587 & 30.837 & 0.620 & 14.587 & 30.837 & 53.957 \\
\hline 10 & 0.482 & 29.462 & 2.916 & 0.482 & 37.523 & 2.372 & 59.622 \\
\hline 11 & 0.415 & 31.676 & 6.014 & 0.400 & 36.029 & 4.368 & 59.206 \\
\hline $1,2,15 \mathrm{p}$ & tos amare & & & & & & \\
\hline $3,6,9,10$ & 4 pontos & ancos & & & & & \\
\hline 4,8 , pont & cinza & & & & & & \\
\hline $5,11,12$ & ntos preto & & & & & & \\
\hline 7,13 pon & s laranja & & & & & & \\
\hline
\end{tabular}

Tabela 19. Resultados das análises de solo novo da Área 8 sem vegetação à M.E.

\begin{tabular}{|c|c|c|c|c|c|c|c|}
\hline & \multirow{2}{*}{\multicolumn{7}{|c|}{$\begin{array}{l}\text { Lâmina } 7 \text { Amostra de solo indeformado do Campo Santa Rosália } \\
\text { Área } 8 \text { solo novo revegetado há } 2 \text { anos }\end{array}$}} \\
\hline & & ovo reve & do há 2 & & & & \\
\hline & \multicolumn{3}{|c|}{ Profundidade $40-46 \mathrm{~cm}$} & & & & \\
\hline & & & & & & & \\
\hline Ponto & $\mathrm{SiO2}$ & $\mathrm{A} 1203$ & $\mathrm{Fe} 2 \mathrm{O} 3$ & $\mathrm{Si}$ & $\mathrm{Al}$ & $\mathrm{Fe}$ & 0 \\
\hline 1 & 4.728 & 62.181 & 0.000 & 2.395 & 37.124 & 0.000 & 60.479 \\
\hline 2 & 1.981 & 12.334 & 43.919 & 1.827 & 13.412 & 30.494 & 54.267 \\
\hline 3 & 4.097 & 79.539 & 0.489 & 1.656 & 37.094 & 0.149 & 60.301 \\
\hline \multicolumn{2}{|c|}{1,3 pontos brancos } & & & & & & \\
\hline \multicolumn{2}{|c|}{2 ponto preto } & & & & & & \\
\hline
\end{tabular}

Tabela 20. Resultados de análises de solo novo da Área 8 à M.E.

\subsubsection{DISCUSSÕES PARCIAIS}

O estudo ao microscópio revelou modificações importantes no sistema de poros; nos solos naturais este sistema está bem desenvolvido e interconectado e nos solos novos houve diminuição dos espaços porais com mudanças de forma e interrupção das fissuras, além da formação de poros novos em forma de cunhas. As fissuras podem estar parcial ou totalmente revestidas por cutãs do tipo cristalária ou não. Este rearranjo não é favorável ao desenvolvimento da vegetação num primeiro instante, 
pois as raízes finas não recebem água e demais nutrientes da mesma maneira que num sistema poral bem desenvolvido.

Os efeitos dos movimentos de terra no preparo atingem as microestruturas deformando e interrompendo o sistema poral que posteriormente recebe soluções que se precipitam e desenvolvem revestimentos (cutãs iluviais e neoformações). Muitos destes poros ou fissuras são totalmente revestidos, o que impede o funcionamento deste vazio para transporte de liquidos e gases.

Considerando o preparo e o uso de calcário e termofertilizante, além dos fertilizantes comuns, algumas questões surgem para explicar principalmente este fenômeno de revestimento e interrupção das fissuras. É sabido que o termofertilizante, contendo sílica e em presença de ácidos orgânicos dos solos, sofre dissolução e liberação dos nutrientes contidos inclusive a sílica. Esta, em presença de alumínio em solução tende a formar caulinita e, no caso de haver excesso de alumínio, que é o caso, há formação de gibbsita. Esta associação caulinita-gibbsita parece comum nestes solos, tanto nos naturais como nos novos.

Para confirmar esta idéia da precipitação de caulinitas e gibbsitas nas fissuras foram marcados pontos nas lâminas, tanto sobre os plasmas e cristais de minerais secundários em solos natural como em plasmas e em cristalárias de lâminas de solos novos e foram analisadas em microssonda eletrônica.

A predominância da composição aluminosa em plasmas de cores branca, amarelo, alaranjado, marrom mostra que os plasmas gibbsíticos predomina nos materiais dos solos tanto os naturais como os novos cujas cores variam em função dos teores variáveis de óxidos hidratados de ferro existentes nos plasmas e presença de matéria orgânica.

A caulinita é menos predominante nos materiais, aparecendo em grande quantidade no solo novo da Área 6 reabilitado há 12 anos. Materiais analisados que apresentaram predominante composição de alumínio e silica secundariamente pode ser que o ponto estava entre material gibbsítico com pouca caulinita. Como foi visto ao M.E.V. placas de caulinita estão justapostas a cristais prismáticos de gibbsita. As cristalárias (veios brancos) têm composição mineralógica de caulinita (pontos que caíram na linha da caulinita nos diagramas triangulares) e de gibbsitas, conforme observação ao microscópio óptico de cristais de prismas alongados justapostos em muitos revestimentos de poros. 
De modo geral os materiais dos solos apresentam composição química rica em alumínio e ocorrem nos diferentes tipos de plasma secundário e a caulinita ocorre nos solos naturais em alguns plasmas ricos em aluminio e nas cristalárias associadas aos cristais de gibbsita. A mobilidade do ferro e do aluminio é menor nestes solos pois estes elementos aparecem na grande maioria dos plasmas, e a sílica que aparece em pouca quantidade é a mais mobilizada.

\subsection{EXPERIMENTO DA SOLUBILIDADE DO ALUMINIO}

O equipamento (figura 6) foi montado para desenvolver o experimento com solo e bauxita destinado a estudar dois aspectos importantes para completar esta pesquisa: a solubilidade do minério e o papel do solo como agente redutor desta solubilidade, e as mudanças das características das águas depois de pecolar o solo e a bauxita, além de composições entre porções de solo sobre porções de bauxita.

\begin{tabular}{|c|c|c|c|c|c|}
\hline Amostra & $\mathrm{pH}$ & $E h(m V)$ & C.E. $\mu S / \mathrm{cm}$ & Temperatura & Teor de Al \\
\hline água pura & 5.5 & 310 & 3.1 & 24 & $<1.0 \mathrm{ppm}$ \\
\hline 10 conjunto & 5.5 & 260 & 50 & 24 & $<1.0 \mathrm{ppm}$ \\
\hline $\begin{array}{c}20 \\
\text { conjunto }\end{array}$ & 4.9 & 340 & 8.6 & 24 & $1.1 \mathrm{ppm}$ \\
\hline 3o conjunto & 6.0 & 265 & 15 & 24 & $<1.0 p p m$ \\
\hline 40 conjunto & 6.9 & 210 & 23 & 24 & $<1.0 \mathrm{ppm}$ \\
\hline
\end{tabular}

Tabela 21. Os resultados das medidas após 24 horas de percolação 


\begin{tabular}{|l||c||c|c||c|c|}
\hline Amostra & $\mathrm{pH}$ & Eh & C.E. & temperatura & teor de Al \\
\hline água pura & 5.7 & 310 & 3.1 & 21 & $<1.00 \mathrm{ppm}$ \\
\hline 10 conjunto & 6.0 & 205 & 130 & 21 & $<1.00 \mathrm{ppm}$ \\
\hline 20 conjunto & 4.9 & 270 & 116 & 21 & $2.8 \mathrm{ppm}$ \\
\hline 3o conjunto & 5.8 & 240 & 136 & 21 & $<1.00 \mathrm{ppm}$ \\
\hline \hline 40 conjunto & 6.1 & 230 & 115 & 21 & $<1.00 \mathrm{ppm}$ \\
\hline
\end{tabular}

Tabela 22. Os resultados das medidas após 168 horas de percolação

Os resultados referentes ao 20 conjunto, onde a água percolou apenas a bauxita, indicam que o $\mathrm{pH}$ torno-se mais ácido, passando de 5.5 para 4.9 tanto no período de 24 horas como no período de uma semana. No caso dos demais conjuntos $\circ \mathrm{pH}$ aumentou em presença do solo, de 5.5 para 6.0. O Eh diminuiu onde a água percolou o solo e manteve-se alto em contato com a bauxita o que mostra que a diferença de potencial da água diminui ao percolar o solo enquato de mantém alta após percolar a bauxita pura.

$\mathrm{O} \mathrm{pH}$ mais ácido dissolve mais o alumínio, cujo $\mathrm{pH}$ de solubilidade está na faixa menor que 4 e maior que $8 . \mathrm{O} \mathrm{pH}$ da água que percola o solo aumenta ou seja diminui a quantidade de ions $\mathrm{H}+$, ou a reatividade da água. Caberia este tipo de estudo principalmente em casos de materiais tóxicos que fazem parte dos estéreis da mineração que precisam ser reabilitados e também precisam neutralizar a ação das águas na solubilidade dos íns tóxicos. Os solos com teores altos de alumímio são considerados tóxicos à vegetação e geralmente os teores de hidrogênio livre $(\mathrm{H}+)$ são altos também.

$\mathrm{Na}$ Área 8 foram analisados os teores de $\mathrm{Al+++}$ e $\mathrm{H}+$ na sub-área revegetada com capim-gordura e na área-piloto, e os resultados mostraram que em alguns niveis estão com teores acima ou próximo do limite tolerável pelas plantas $(0.5 \mathrm{mg} / 100 \mathrm{~g}$ de solo) na área-piloto (sem vegetação). 


\begin{tabular}{|l|l|l|}
\hline Área 8 (revegetada) & Al $^{3+}$ & $\mathrm{H}+$ \\
\hline $0-10 \mathrm{~cm}$ & 0.26 & 0.41 \\
\hline $10-20 \mathrm{~cm}$ & 0.23 & 0.51 \\
\hline $20-30 \mathrm{~cm}$ & 0.21 & 0.40 \\
\hline $30-40 \mathrm{~cm}$ & 0.01 & 0.40 \\
\hline $40-50 \mathrm{~cm}$ & 0.01 & 0.27 \\
\hline
\end{tabular}

Tabela 23. Resultados das análises de $\mathrm{Al}^{3+} \mathrm{e}^{+}$nos solos

\begin{tabular}{|l|l|l|}
\hline Área 8 sem vegetação & Al3+ & $H+$ \\
\hline $0-10 \mathrm{~cm}$ & 0.40 & 0.66 \\
\hline $10-20 \mathrm{~cm}$ & 0.59 & 0.56 \\
\hline $20-30 \mathrm{~cm}$ & 0.55 & 0.58 \\
\hline $30-40 \mathrm{~cm}$ & 0.02 & 0.45 \\
\hline $40-50 \mathrm{~cm}$ & 0.01 & 0.29 \\
\hline
\end{tabular}

Tabela 24. Resultados das análises de Al3+e $\mathrm{H}+$ nos solos

Nas profundidades entre 10 e $30 \mathrm{~cm}$ os teores de aluminio excedem os limites permissiveis para as plantas e estão na área-piloto onde não foi feito plantio nem semeadura. Possivelmente toda área, antes da revegetação tinha teores elevados de alumínio livre. O desenvolvimento da vegetação reduziu esses teores ou é possivel também que haja uma concentração destes íons em áreas sem vegetação.

\subsubsection{DISCUSSÕES PARCIAIS}

O experimento mostrou que sob ação das chuva a bauxita sofre a ação da atividade das águas e libera o alumínio que pode ir para as águas superficiais e subterrâneas. O uso de uma camada de solo natural da região, retirado dos $10 \mathrm{~cm}$ iniciais, funcionaram como sistema redutor da atividade da água que ao percolar a bauxita abaixo dissolveu muito menos o alumínio, a níveis abaixo de $0,1 \mathrm{ppm}$. No solo também existe bauxitas de baixos teores, mas em áreas sem vegetação ocorre um aumento da disponibilidade de alumínio, enquanto em áreas revegetadas os teores ficam dentro dos limites permissiveis para a vegetação. Neste caso a atividade da matéria orgânica e da microfauna sobre o alumínio dos solos produz complexos pouco solúveis que reduzem também a liberação deste ion. Desta maneira a importância do solo é muito grande nesta atividade de reduzir a solubilidade do alumínio. 
Em outros casos, com outros tipos de minério, experimento semelhante pode ser desenvolvido para avaliar este comportamento do solo para evitar problemas até então sem solução para controle de poluição de vários rejeitos de mineração. 


\section{CAPITULO 5}

\section{CONCLUSÕES E SUGESTÕES TÉCNICAS}

\subsection{CONCLUSÕES}

As transformações pelas quais os materiais lateríticos passam, sob ação dos processos pedogeoquímicos de superfície, do preparo das áreas e das substâncias adicionadas, conduzem a adaptações que reestruturam pedologicamente os materiais e otimizam o desenvolvimento da vegetação neles plantada. Neste sentido, as medidas tomadas para caracterizar os solos naturais e os novos mostraram as semelhanças e as diferenças entre os materiais e evidenciaram o grau de evolução da reabilitação dos solos.

O estudo da matéria orgânica total e carbono mostrou que estes parâmetros refletem de forma evidente a evolução da reabilitação; os solos naturais, com alto grau de pedalidade e vegetação instalada, apresentam teores mínimos de $3 \%$ de carbono e $5 \%$ de M.O.T. enquanto que os solos novos apresentam teores mais baixos. Nestes, os teores mais altos ( $2 \%$ de carbono e $2,5 \%$ de M.O.T.) correspondem à reabilitação melhor sucedida, e os teores mais baixos $(0.2 \%$ de carbono e $1.1 \%$ de M.O.T.) correspondem aos solos com mais dificuldade para fixar a vegetação e para iniciar o desenvolvimento da reestruturação do solo.

O estudo da textura dos solos novos mostrou que ocorreu perda dos finos e da matéria orgânica associada nas partes superficiais, por ausência da vegetação. No entanto, nas áreas onde houve desenvolvimento da vegetação, os solos foram protegidos e desenvolveram a estruturação pedológica, com fixação da matéria orgânica e das classes granulométricas mais finas.

As mudas de arbóreas e arbustivas em geral possuem quantidades variáveis de raizes finas mas as gramíneas, além de possuirem somente este tipo de raiz, ainda apresentam um desenvolvimento lateral (ramificação) que ajuda muito na fixação das frações finas. A espécie de graminea que mais se desenvolveu foi o capim-gordura, que apresenta, contudo, o problema de secar totalmente na estiagem, diminuindo a proteção ao solo. Uma espécie arbustiva (Cássia speciosa) também apresentou um bom desenvolvimento de raizes finas e de indivíduos muito próximos, formando capoeira (vegetação fechada). Esta espécie vegetal da familia mimosóide tem um 
papel muito importante, que é o de fixar em suas raizes bactérias que sintetizam nitrogênio e fixam este elemento no solo. A sucessão desta graminea e desta arbustiva apresentaram um bom resultado para o desenvolvimento do solo.

A evolução das macroestruturas está associada à evolução de microestruturas e o estudo das pedofeições em solos naturais ajudou muito a comparar a evolução destas microestruturas nas áreas reabilitadas de diferentes idades. As áreas com dificuldade para desenvolver a vegetação apresentam o sistema de fissuras muito modificado, com interrupção e revestimento total ou parcial do sistema poral. Considerando que este sistema representa os caminhos para a circulação de água, nutrientes e gases para as plantas e animais associados, as modificações de origem física (preparo com máquinas) e de origem pedogeoquímica acelerada pelas substâncias químicas adicionadas iniciam um processo de fechamento das fissuras num primeiro momento e a atividade biológica das raízes, formigas e cupins é responsàvel pela inversão do processo, construindo passagens ou biotubos além de contribuírem com restos orgânicos que são substâncias importantes nos processos macro e micropedogenéticos.

O estudo microestrutural dos solos permitiu visualizar o arranjo geral dos seus componentes e a disposição dos poros, permitindo uma comparação evolutiva dos solos naturais em relação aos novos. O estudo microgeoquímico à microssonda eletrônica foi importante para identificar o processo geoquímico que ocorre, com o revestimento dos poros, talvez ampliado pelas substâncias adicionadas no preparo das áreas para a revegetação. Nos solos naturais, os revestimentos de poros são principalmente ferruginosos, enquanto que nos solos novos, principalmente gibbsíticos. Neste aspecto, o estudo mostrou que o mecanismo de gibbsitização, responsável pela formação das jazidas da área, continua ocorrendo, sob ação da pedogênese, nos materiais retrabalhados pela reabilitação, e em curto intervalo de tempo.

A importância da reabilitação de áreas mineradas reside não somente na fixação da vegetação mas também no desenvolvimento pedológico dos materiais. Os solos assim desenvolvidos passam a reduzir a atividade das águas de chuva tanto na erosão como na dissolução de elementos ou substâncias tóxicas existentes nos materiais descartados pela mineração. A passagem para os recursos hídricos superficiais ou subterrâneos destas substâncias ou ions tóxicos podem atingir tanto a vegetação como os animais $e$, no caso de cidade próxima, a população. $O$ experimento com solo e bauxita mostrou que uma camada de solo (que pode ser 
dimensionada em experimento semelhante) pode reduzir a teores abaixo dos limites de detecção a solubilidade do alumínio, que, em contato direto com água, seria solubilizado. De modo geral, a reabilitação dos solos recompõe a paisagem profundamente modificada pela mineração e protege os recursos hidricos de substâncias ou íons tóxicos, evitando problemas para a vegetação e para os demais consumidores.

\subsection{SUGESTÕES TÉCNICAS}

A experiência adquirida ao longo desta pesquisa mostrou algumas soluções para problemas que vêm ocorrendo nos programas de recuperação de áreas mineradas. Algumas sugestōes e explicações podem fornecer subsidios para que sejam otimizados os trabalhos de reabilitação destas áreas.

A primeira preocupação deve ser quanto ao futuro uso da área para que seja planejada a sua recuperação. As opções são muitas, mas estão principalmente voltadas ao reflorestamento. Em geral, as empresas de mineração procuram deixar a área com a vegetação que pode trazer retorno a médio prazo. Uma vez implantadas as leis ambientais a revegetação é exigida quando a área mantinha uma floresta ou alguma reserva de vegetação típica. Esta é a opção mais difícil e sem retorno direto. Em outros casos a área estava sendo usada para agricultura ou o proprietário decidese por reflorestamento. Nestes casos são usadas mudas de Eucaliptus ou Pinus, que podem representar um retorno sem muitos investimentos para o proprietário. Raramente tenta-se ocupar a área com a cultura inicialmente explorada.

Após esta decisão sobre o futuro uso é importante programar os trabalhos para que o preparo da lavra e a própria explotação tenha em conta a reabilitação. $O$ desmatamento pode ser precedido pela colheita de sementes, aproveitamento da serapilheira (liteira) e o solo dos primeiros $20 \mathrm{~cm}$ deverá ser extraído por máquinas e armazenados sem muito revolvimento, mantendo ao máximo suas estruturas. Este trabalho exige a disponibilidade de área para armazenagem de serapilheira e de solo, além do aproveitamento das sementes para serem desenvolvidas em viveiro.

Concluida a lavra o terreno estará profundamente modificado e a próxima etapa é então o seu preparo para receber o solo, as sementes e as mudas. O preparo pode
ser feito de várias maneiras: 
1. movimento de grandes volumes de terra para entulhar grandes cavidades esvaziadas,

2. suavizamento dos terrenos de onde foram retiradados volumes esparsos dentro do manto laterítico,

3. modificações topográficas para outros usos que não somente a revegetação, como áreas de lazer, lagoas para piscicultura e etc,

4. recuperação das pilhas dos materiais não aproveitados, tais como estéreis e rejeitos,

5. recuperação das áreas que foram barradas para receberem os efluentes mais finos.

Estes diferentes tipos de preparo dos terrenos minerados ou todos eles associados, estarão sujeitos a revegetação, que é a principal meta e a mais complexa.

Etapas a serem seguidas:

Antes da lavra:

1.retirada e armazenamento da serapilheira

2. retirada e armazenamento do "top-soil"

Após a lavra:

3. preparo do terreno para receber os materiais acima descritos

4. análise dos materias preparados antes e depois da adição do "top-soil" e da serapilheira.

Escolha das espécies vegetais:

5. estudo das espécies nativas e desenvolvimento em viveiro

6. estudo das espécies pioneiras e desenvolvimento em viveiro

7. escolha das mudas de espécies definitivas ou primárias

8. estudo do período do ano mais favorável para o plantio com base na pluviometria

Acompanhamento de campo:

9. estudo do desenvolvimento do solo

10. estudo do desenvolvimento das espécies vegetais

11. estudo do aparecimento das espécies animais

12. avaliação da retomada espontânea das espécies de áreas vizinhas

As etapas 1 e 2 são simultâneas e os materiais podem ser misturados ou separados. A etapa 3 requer um estudo do possivel suavizamento da área e a abertura 
de suicos paralelos às curvas de nivel para minimizar a erosão pelas chuvas. A análise dos materiais se presta para definir a necessidade de fertilizantes e corretivos, comparando-se com as características dos solos naturais. A adição do "top-soil" e da serapilheira pode ser posterior ao preparo, quando o tempo de armazenagem foi longo ou pode preceder a subsolagem ou abertura dos sulcos.

A escolha das espécies vegetais para o plantio deve acompanhar o estudo prévio da vegetação típica da área, o que facilita a retomada das espécies das áreas vizinhas não atingidas pela mineração. As espécies pioneiras devem ser usadas de modo a suprir as necessidade de preparo do microambiente do solo, por isto sua importância. Obviamente o preparo das mudas deve preceder a fase de plantio.

A escolha da época mais favorável para o plantio é um fator importante para que as chuvas sejam suficientes para umidecer o solo mas não causem a erosão capaz de remover parte dos materiais preparados. As chuvas que mais se enquadram neste requisito são as de 100 a $150 \mathrm{~mm}$ num mês, ou seja, em torno de 3 a $5 \mathrm{~mm}$ por dia. O material preparado pode absorver esta quantidade de água sem que ocorra grande escoamento superficial.

Para evitar que chuvas fortes possam prejudicar os trabalhos é necessário estudar os dados pluviométricos, através de gráficos com distribuição mensal das chuvas para estabelecer o melhor periodo para o plantio. As chuvas devem medir por volta de $100 \mathrm{~mm}$ num mês para que não falte umidade nem haja erosão forte. Uma vez em desenvolvimento, as raizes das plantas contribuem fortemente para segurar o solo ou os materiais que suportam as sementes.

Durante o desenvolvimento da vegetação é importante que se acompanhe o desenvolvimento do solo, das raizes e da microfauna para se ter certeza que está ocorrendo uma evolução.

Quando ocorre a ocupação de espécies vindas de áreas próximas pode-se considerar que o trabalho foi bem sucedido. Apesar disso o estudo continua até que as espécies permanentes apareçam ou se desenvolvam as inicialmente plantadas.

A reabilitação é um processo dificil uma vez que o solo natural é um produto que evoluiu "in loco", ao longo do tempo, a partir de processos biogeoquímicos que estabeleceram um equilíbrio dinâmico, o qual foi interrompido com as atividades da mineração. A retirada e armazenamento do solo após o desmatamento é um cuidado 
que pode manter algumas das suas caracteristicas naturais: 1. o grau de estruturação original do solo (macro e microagregados), 2. a matéria orgânica também se mantém em grande quantidade como foi visto nesta pesquisa, 3. os materiais mais finos, principalmente as argilas permanecem na ausência de chuvas fortes, principalmente nos agregados.

A área que vai receber o solo anteriormente armazenado deve estar bem drenada e bastante suavizada para que as primeiras chuvas não promovam a total erosão, que levará todo o solo transplantado antes que a vegetação cresça o suficiente para segurar o solo. Em outros tipos de relevo resultante, quando não é possivel fazer o suavizamento, a hidrossemeadura ou a semeadura manual podem ser uma solução. Para tanto, o preparo consiste em abrir sulcos pouco profundos (alguns centímetros) para que as sementes preparadas possam se fixar.

O uso de fertilizantes e de corretivo de acidez depende de estudo prévio do material que receberá o solo armazenado ou "top-soil". As análises de fertilidade definem a disponibilidade de nutrientes nos materiais do substrato preparado.

A opção de uso do termofertilizante foi determinada pela liberação lenta dos nutrientes que este fertilizante propicia porque à superficie os fertilizantes comuns são carreados ou abvsorvidos na primeira etapa do desenvolvimento da vegetação, restando muito pouco para a fase seguinte. Além disso o termofertilizante é feito a partir de rochas fundidada e resfriadas bruscamente e não contém substâncias químicas artificiais.

Considerando o tipo de preparo do terreno, o terraceamento é menos eficiente que o suavizamento das áreas, construindo novas drenagens intercaladas no contato entre superficies adjacentes. O revolvimento do solo promovido por implementos agrícolas é desfavorável pois ajuda a compactar e destruir as estruturas dos materiais. O uso do top-soil que foi retirado antes da lavra deve ser feito de maneira a não destorroá-lo muito, mantendo assim alguns do agregados pré-existentes. Não se aconselha misturar o top-soil ao material usado para suavizamento do terreno.

A armazenagem do top-soil deve ser do tipo mais simples possivel, atentando para não revolvê-lo e desestruturá-lo. O uso de fertilizantes e de pó calcário, normalmente distribuido após a adição de todos os materiais (alteritas e top-soil) precede o uso do implemento subsolador. Esta ordem deve ser modificada, deixando o top-soil para o fim do preparo e da subsolagem. O top-soil vai compor uma camada de 
alguns centimetros e pode ser lançado acima de tudo, mesmo acima da subsolagem, nos sulcos abertos.

O uso de pó calcário para elevar o pH não mostrou eficiência, pois a alteração foi mínima e não parece ser a causa do mal desenvolvimento dos solos novos. Além disso pode ter sido o calcário o material que promove a dissolução de silicatos existentes no termofertilizante usado. Esta solução penetra pelos poros e em condições favoráveis vêm a se cristalizar e fechar o poro, impedindo os movimentos de água, nutrientes e gases para as plantas em desenvolvimento.

A distribuição de serapilheira em áreas-teste mostrou que um grande número de espécies secundárias pode ser desenvolvida em viveiros e usada nas próximas revegetações. É obvio que as espécies secundárias são as preparadoras dos solos para receber as espécies definitivas das matas.

O uso do capim gordura mostrou ser uma forrageira de crescimento fácil e bom, ajudando na manutenção da umidade, evitando a evaporação direta, além de amortecer as gotas de chuva e diminuir a erosão dos solos. O controle do capimgordura já se mostrou possivel, usando vegetação mais sombreadora associada (leguminosa) que acaba transformando-o em adubo verde. 


\section{REFERÊNCIAS BIBLIOGRÁFICAS}

Alen, B.L. \& Hajek, B.F., 1989, "Mineral Occurence in Soil Environments", In: Dixon, J.B. \& Weed, S.B. (eds) Mineral in Soil Environments. 2a.ed. Madison, SSSA, p.199-278. (Soil Science Society of America Book Series, 1)

Anderson, J.M. \& Ingram, J.S.I. ,1983, "Tropical Soil Biology and Fertility: A Handbook of Methods - UNESCO - ISSS, C.A.B. International, 120pp.

Atkinsons, K.. ; Edwards, R.P.; Waller,C., 1990, "Roles of Industrial Minerals in Reducing the Impact of Metalliferous Mine Waste in Cornwall" Transaction of Mining and Metallurgy, Vol 9: Al58-Al72.

Biella, L.C. ; Farrenberg M.L.A. ; Toledo, A.E.P., 1989, "Recuperação de Áreas Degradadas - Áreas de Empréstimo" In: Seminário Nacional de Grandes Barragens, 18 Foz do Iguaçu, 1989, Anais, Foz do Iguaçu, CESP 24pp.

Bocquier, G. ; Muller, J.P. et Boulange, B. , 1975, "Les laterites: conaissance et perspectives actuelles sur les mecanismes de leur differenciation", 30pp.

Bolin, B., 1991, The greenhouse effect, climatic changes and ecosystem. Ed. Bert Bolin el al, Chichester: Wiley - Interscience Publication, New York. 541pp.

Brewer, R. \& Sleeman, J.R., 1988, "Soil structure and fabric: their definition and description' . J. Soil Sci. 11:172-185.

Briassoulis, H., 1989, "Theoretical Orientation in Environmental Planning: An Inquiry into Alternative Approaches". Environmental Management, 12 (4): 381-392.

Brookins,D.G., 1987, Eh-pH Diagrams for Geochemistry. Berlim, Springer. 176pp.

Bui, E.N. ; Mermut, A.R. ; Santos M.C.D., 1989, "Microscopic and Ultramicroscopic Porosity of an Oxisol as Determined by Image Analysis and Water Retention". Soil Science Society of American Journal, 53:661-665.

Bullock, P.; Federoff, N.; Jongerius, A.; Stoops, E.; Tursina, T., 1985, "A handbook of soil thin section description". Published by Intern. Soc. of Soil Sci, 152pp.

Cambier, P. \& Protz, R. , 1981, Etude des association argeli-oxide organization des constituants d'un materieu ferralitique. Agronomic, 1 (9):713-722.

Castro, S.S., 1990, "Compilação organizada para estudo de micromorfologia do solo: pequeno guia para descrição de lâminas delgadas, 87pp.

Cerri. C.C.; Eduardo,B.P.;Piccolo, M.C., 1990, "Métodos de Análises em Matéria Orgânica do Solo" - Centro de Energia Nuclear na Agronomia (USP-SP), 30pp 
Chauvel, A. ; Grimaidi, M. ; Tessier, D. , 1991, "Changes in soil pore-space distribution following deforestation and revegetation: An example from the Central Amazon Basin, Brazil. Forest Ecology and Management, 38:259-271.

Dias, A.C., 1980, "Recuperação de áreas mineradas", Anais do III Congresso Brasileiro de Conservação do Solo, Brasiilia.

Dias, A.C., 1981, "Recomposição paisagística de áreas mineradas de bauxita", Anais do Simpósio Nacional de Ecologia, Belo Horizonte, M.G.

Dias, A.C., 1981, "Reabilitação de áreas mineradas de bauxita" Anais do XII Congresso Brasileiro de Agronomia, Guarapari, E.S.

Dias, A.C., 1982, "Reabilitação de áreas mineradas de bauxita", Anais do 40 Congresso Florestal Brasileiro, Belo Horizonte, M.G.

Dias, A.C., 1983, Reabilitação de áreas mineradas de bauxita em Poços de Caldas, M.G., apresentado pelo Grupo de trabalho sobre poluição do solo do Instituto Brasileiro de Mineração - IBRAM, Poços de Caldas.

Dias, A.C., 1985, "Reabilitação de áreas mineradas", Anais do I Congresso Brasileiro de Mineração, Brasilia, publicado também no volume "Coletânea de Trabalhos Técnicos sobre Controle Ambiental na Mineração, Editado pelo DNPM, Brasília, 1985, pg 175.

Dixon, J.B., 1989, "Kaolin and Serpentine Group Minerais. In: Dixon, J.B. \& Weed,S.B. (eds). Minerals in Soil Environments, 2a. ed Madison, SSSA. 467-525. (Soil Science Society of America Book Series, 1).

Drees, L.R. ; Wilding, N.E. ; Senkayi, A.L., 1989, "Sílica in soils: quartz and disordered silica polimorph. In: Dixon, J.B. \& Weed, S.B. (eds). Minerals in Soil Environments. 2a.ed, Madison, SSSA, 913-934. (Soil Science Society of America Book Series, 1).

Douglas, L.A., 1985, "Soil micromorphology and soil classification" ed SSS of Am. $350 p$ p.

Ellert, R., 1959. "Contribuição à Geologia do Maciço de Poços de Caldas. Bol Fac. Fil Ciên. Letras. Univ. São Paulo (Geologia 18), 237:5-63.

Ellert, R., Björnberg, A.J.S. and Coutinho, J.M.V., 1959. Mapa geológico do Maciço Alcalino de Poços de Caldas, Brasil. In: R. Ellert, 1959, Contribuição à Geologia do Maciço Alcalino de Poços de Caldas, Brasil. Bol. Fac. Fil. Ciên. Letras, Univ. São Paulo (Geologia 18), 237:5-63. 
Feller, C., 1979, "Une methode de fractionnement granulometrique de la matiere organique des sols, Cahiers d'ORSTOM. Serie Pedologie, 18 (4):339-346.

Fernandez-Rubio, R. ; Lorca, S.F. ; Arlegim, J.E., 1986, "Abandono de Minas - impacto hidrológico. Spain, Instituto Geologico e Minero". 267pp.

Fyfe, W.S., 1981, "The Environmental Crisis: Quantifying Geosphere Interactions". Science, $223(3): 105-110$.

Galle, P., 1986, "La toxicité de l'aluminium". La Recherche, 17:766-775.

.Gascuell-Odoux, C., 1986, "Utilizations de la geostatistique pour l'étude des variations spatiales du transfert de l'eau dans le sol"., Hydrogeologie 2:147-152.

Gascuel-Odoux, C., 1987, "Variabilité spatiale des propriétés hydrique du sol. Methode et résultats; cas d'une seule variable: revue bibliografique, Agronomic, 7 (1):61-7.

Goeller, H.E. \& Zucker, A., 1984, "Infinite Resources: The ultimate strategy", Science, $223(3): 456-461$.

Golley, F.B.; McGinnis, J.T.; Clements, R.G.; Cild, G.I.; Duever, M.J., 1978, "Ciclagem de Minerais em Ecossistema de Floresta Tropical Húmida" São Paulo, EPU, 258pp.

Graedel, T. E., 1989, "Regional and Global Impacts on the Biosphere". Environment, $31(1): 8-13,36-41$.

Grimaldi, M. \& Boulet, R. , 1990, Relation entre l'espace poral et le fontionnement hydrodinamique d'une couverture pedologique sur socle de Guyane Française". Cahiers d'ORSTOM, Serie Pédologie. 25 (3) :263-275.

Groot, R.S. de, 1987, "Environmental Function as a Unifying Concept for Ecology and Economics. The Environmentalist, 7 (2): 105-109.

Helgeson, H.C., 1968, "Evaluation of irreversible reaction in geochemical processes involving minerals and aqueous solutions- 1 . Thermodynamic relations", In: Geochimica e Cosmochimica Acta, 32:853-877.

Hsu, P.H., 1989, "Aluminium Oxides and Oxihydroxides" in Dixon, J.B. \& Weed, S.B.(eds) Minerals in soil environments. 2a ed. Madison, SSSA, 331-368. (Soil Science Society of America Book Series, 1).

Icole, M., 1984, "Various ways of approaching rock weathering: lessons and applications. Soc. Nat. Elf-Aquitaine.

Jacobs, M., 1988, "The Tropical Rain Forest - AFirst Encounter, Berlim. SpringerVerlag, 259p. 
Johnson, W.M.; McCelland, J.E.; McCaleb, S.B.; Ulrich, R.; Harper, W.G. \& Hutchings, T.B., 1960, "Classification and description of soil pores". Soil Science. 89:319312.

Jonhson, A.R. , 1988, "Diagnostic Variables as Predictors of Ecological Risk", Environmental Management, 12(14):515-523.

Jordan, C.F., 1985, : "Nutrient Cycling in Tropical Forest Ecosystems - Principles and their Application in Management and Conservation, Chichester, Joh Wiley and sons, 190p.

Krauskopf, K.B., 1979, Introduction to Geochemistry, 2a. ed. Tokio, Mcgraw-Hill Kogakusha, $617 \mathrm{p}$.

Kubiena, W.L., 1938, "Micropedology". Collegiate Press Inc., Ames, lawa. 243pp.

Lucas, Y.; Chauvel, A.; Ambrosi, J.P. , 1986, Processes of aluminium and iron accumulation in latossols developed on quartz-rich sediments from Central Amazonia (Manaus - Brazil). In: Rodrigues-Clement \&

Tardy, Y. Geochemistry and Mineral Foramtion in Earth Surface - Proceeding of the International Meeting "Geochemistry of the earth surface and processes ao mineral formation, held in Granada. Spain. 289-300p.

Marcos, Z.Z., 1982, "Ensaio sobre epistemologia pedológica. 1. Definição de solo. 2. Natureza e Comportament do solo. Cahiers d'ORSTOM, Serie Pédologie, 19(1):528.

Mason, B. ; Moone, C.B., 1982, "Principles of Geochemistry, 4a.ed. New York, Jonh Wiley \& sons. 344p.

Mello,L.G.F.S., 1990, Disposição de rejitos de mineração e suas implicações ambientais. Saneamento Ambiental, 10: p.

Mermut, A.R., 1992, Introduction to Soil Micromorphology, University of Saskatchewan. Department of Soil Science. Saskatoon, SK. Canada, 115p.

Moniz, A.C. ; Medina, H.P., 1972, Elementos de Pedologia. São Paulo, Poligono. 459p.

Nahon, D. , 1986, "Microgeochemical environmental in lateritic weathering". In: Rodrigues-Clement ${ }^{\wedge}$ Tardy, Y. Geochemistry and mineral formation in the earth surface"- Proceeding of the international meeting held in Granada, 141-156.

Oades, J.M., 1989, "An Introduction to Organic Matter in Mineral Soils. In: Dixon, J.B. \& Weed, S.B. (eds). Minerals in Soil Environments, 2a.ed Madison, SSSA. 89-156.

Odum, E.P., 1969, "Teh strategy of ecosystem development. Science, 164 (18):262268. 
Pa, H.H., 1989, "Aluminium Oxides and Oxihydroxides. In: Dixon, J.B. \& Weed, S.B. (eds) Mineral in Soil Environments. SSSA Soil Science Society of America Book Series, 1. 7:331-378.

Prigogine, I., 1978, "Time, structure, and Fluctuation'. Science 201 (4358):777-785.

Paula, J.R. de, 1992, "Estudo da influência das substâncias húmicas na absorção de metais por plantas através de técnicas analiticas. São Carlos, 93p. (Dissertação de Mestrado- Instituto de Física e Química- USP)

Pedro, G., 1987, Geochimie, mineralogie et organisation des sols. Aspects coordennés des problémes pedogénétiques. Cahiers d'ORSTOM, serie Pédologie 23(3):169186

Pedro, G. 1982, "Papel e influência das características mineralógicas sobre as modalidades de organização dos materiais argilosos nas condições de meio superficial". Inst. National de la Recherche Agronomique. 90p

Pedro, G., 1987, Géochimie, minéralogie et organisation des sols: aspects coordonnés des problèmes pédogénétiques, Cah. dÓRSTOM, ser. Pédol., vol XXIII, 3:169186.

Protz, R; Teesdale, W.I. ; Campbell, J.A. ; Duke, C. , 1992, "Earthworm transport of heavy metals from sewage sludge: a micropixe application in soil science, Papers of University of Guelph, Ontario, Canada, N1G 2W1. 275-287.

Protz, R.; Sweeney, S.J. and Fox, C., 1992, "An Application of spectral image analysis to soil micromorphology, 1. Methods of analysis". Geoderma, 53:341-355.

Rai, D. ; Kittric, J. , 1989, "Mineral equilibria and the soil system". In: Dixon, J.B. \& Weed, S.B. (eds). Minerals in Soil Environment 2a.ed. Madison, SSSA (Soil Science Society of America Book Series, 1) 161-198.

Reichardt, K. , 1985, Processos de transferência no sistema solo-planta-atmosfera. 4a. ed Campinas, Fund. Cargill.

Ricklefs, R.E., 1987, "Community Diversity: Relative rules of local and regional processes. Science. 235(9):167-171.

Ruellan, A. , 1987, "Soil vertical and lateral differentiation". 120p

Ruellan, A. ; Dosso, M. ; Fritch, E. , 1989, L'Analise structural de la couverture pédologique. Science du sol. 27 (4):319-334.

Ruellan, A., 1987, "Contribuição das pesquisas em zona tropical ao desenvolvimento da ciência do solo. In: Congresso Brasileiro de Ciência do Solo, 21

Ruellan, A. , 1988, As estruturas da cobertura pedológica. 55p. 
Ruellan, A., 1991, "Soil vertical and lateral differentiation. 120p

Santos, M.C.D. ; Mermut, A.R. ; Ribeiro, M.R. , 1989, "Submicroscopy of Clay Microaggregates in an Oxisol from Pernambuco, Brazil. Soil Science Society od American Journal 55:1895-1901.

Schaeffer, D. J. ; Herricks, E.E. ; Kerter, H.W. , 1988, Ecosystem Health: 1. Measuring Ecosystem Health. Environmental Management. 12 (4):445-455.

Schnitzer, M. \& Schuppli, P, 1989, Method for the Sequential Extraction of organic Matter from Soil Fraction. Soil Science Society American Journal. 53:1418-1424.

Schorscher, H.D. \& Shea, M.E., 1992, " The regional geology of the Poços de Caldas alkaline complex: mineralogy and geochemistry of selected nepheline syenite and phonolites, Journal of Geochemical Exploration, 45:25-51, Elsevier Science Publishers B.V., Amsterdam.

Schwerrmann, U. \& Taylor, R. M. , 1989, "Iron Oxide In: Dixon, J.B. \& Weed, S.B. (eds) Mineral in Soil Environment 2a. ed. Madison, SSSA (Soil Science Society of American Book Series, 1) 379-438.

Sedjo, R.A., 1989, "Forest - A tool to moderate global warming?, Environmental. 31 (1):8-13,36-41.

Selby, M.J., 1982, Hillslope material and processes. New York, Oxford University Press, 254p.

Stoops G. J. \& Buol, S.W., 1985, Micromorphology of Oxisols. In: Douglas, L.A. \& Thompson, M. L. (eds). Soil Micromorphology and Soil Classification. USA, Soil Science Society of America. p 105-120. (SSSA Special Publication, 15).

Swain, F.M., 1963, Geochemistry of Humus In: Geochemistry Organic. New York, Irving A. Berger.

Sweeney, S.J. ; Protz, R. ; Fox, C.A. , 1992, An Application of Spectral Image Analisis to Soil Micromorphology, 2. Comparizon of two soil profiles. Geoderma, 53:341. 355.

Tardy, Y. \& Novikoff, A. , 1988, "Activité de l'eau et deplacement des équilibres gibbsite-kaolinite dans les profils latéritique. Comptes Rendus Academie Science de Paris. Serie II, 306:39-44.

Tardy, Y. ; Gueddari, M. ; Fritz, B. , 1985, "Equilibres Physico-chimique entre l'eau et les mineraux des argiles - Activité de l'eau et des ions en solution. In: Jean Cases ed. Interations solide-liquide dans les millieux poreux. Paris, Editions Techniques 
Tardy, Y. , 1985, 'Equilibres Physico-chimiques entre l'eau et les mineraux des argiles

- Domaines de stabilité des argiles in interations solide-liquide dans les milieux poreux. In: Jean Cases ed. Interations solide-liquide dans les milieux poreux. Paris, Editions Techniques . 3-18.

Tardy, Y. ; Kehrus, A. ; Rico, R. , 1985, "Equilibres Phhysicochimiques entre l'eau et les mineraux des argiles III - Echanges cationiques, hydratation et gonflement. In: Interations solide-liquide dans les milieux poreux. Paris, Editions techniques. 3348

Tardy, Y. , 1986, Le cycle de l'eau: Climats, paleoclimats e geochimie globale. Paris. Masson. 338p.

Tardy, Y. \& Roquin, C. , 1991, "Geochemistry and evolution of lateritic landscapes. Université Louis Pasteur/CNRS. 30p

Terrible, F. \& FritzPatrick, E.A., 1992, "The Application of multilayer digital image processing techniques to the description of soil thin section. Geoderma. 55:159174.

Ulbrich, M.N.C., 1983, "Aspectos mineralógicos e petroquímicos de nefelina sienitos de Poços de Caldas, M.G.-S.P." Tese de Doutoramento, Instituto de Geociências, Univ. São Paulo, 369pp.

Ulbrich, M.N.C., Gomes, C.B., Ulbrich, H.H.G.J., 1984, "Nefelina sienito do maciço alcalino de Poços de Caldas, M.G.- S.P.: Caracterização mineralógica e petrológica. $33^{\circ}$ Cong. Bras. Geol., Rio de Janeiro, Anais, Vol 9 pp. 4362-4376.

Ulbrich, M.N.C. \& Gomes, C.B., 1981, Alkaline rocks from continental Brazil. Earth Sci. Rev., 17:135-154.

Weissberg, I., 1989, "Aspectos Geoquímicos do Impacto Ambiental da Mineração na Amazônia. Serra dos Carajás, Pará." Disserração de Mestrado apresentada no Instituto de Geociências - USP, 220pp.

Wilding, L.P. \& Flach, K.W., 1985, "Micropedology and Soil Taxonomy. In: Duglas, L.A. \& Thompson M.L. Eds. Soil Micromorphology and Soil Classification. USA, Soil Science Society of America. p1-16 (SSSA Special Publication, 15).

Williams, D.D., 1982, "Recomendações para implantação de programa de reabilitação de áreas mineradas", I Seminário de Lavra à Céu Aberto, Belo Horizonte, IBRAM, Mineração e Metalurgia, 46 (440) p. 41.

Williams D.D., 1984, "Reabilitação de minas de bauxita exauridas em Poços de Caldas, M.G., Anais do Simpósio Brasileiro sobre Técnicas Exploratórias Aplicadas à Geologia, Salvados, Ba., publicado também no Volume "Coletânea 
de Trabalhos Técnicos sobre Controle Ambiental na Mineração" Ed. DNPM, Brasilia, 1985, p 52.

Williams, D.D., 1986, "Reabilitation of mined bauxite lans at Poços de Caldas, Minas Gerais State, Brazil", paper of National Meeting of the American Society for Surface Mining and Reclamation, Jackson, Mississipi.

Zoon, S.V., 1986, Tropical and subtropical soil science. Moscow, Mir Publishers, 355p. 
ANEXOS 
ANÁLISES GRANULOMÉTRICAS

TABELA 1

AREA 1 - SOLO NATURAL DE CAMPO CERRADO

$\begin{array}{cccc}\begin{array}{c}\text { Profund. } \\ (\mathrm{cm})\end{array} & \text { Argila } & \text { Silte } & \text { Areia } \\ (0-10) & 29,27 & 34,86 & \\ (10-20) & 38,86 & 28,89 & 22,65 \\ (20-30) & 35,19 & 30,63 & 19,3 \\ (30-40) & 36,51 & 30,03 & 22,36 \\ (40-50) & 32,74 & 19,86 & 21,29 \\ & & & 37,07\end{array}$

AREA 2 - SOLO NOVO DO RETIRO BRANCO IREVEGETADO HA 3 ANOS

$\begin{array}{cccc}\begin{array}{c}\text { Profund. } \\ (\mathrm{cm})\end{array} & \text { Argila } & \text { Silte } & \text { Areia } \\ (0-10) & 25,9 & 33,26 & \\ (10-20) & 22,74 & 50,53 & 36,96 \\ (20-30) & 28,15 & 52 & 22,7 \\ (30-40) & 26,82 & 53,14 & 15,25 \\ (40-50) & 24,68 & 52,89 & 14,91 \\ & & & 16,85\end{array}$

AREA 2 - SOLO NOVO DO RETIRO BRANCO I REVEGETADO HA 6 ANOS

$\begin{array}{cccc}\begin{array}{c}\text { Profund. } \\ (\mathrm{cm})\end{array} & \text { Argila } & \text { Silte } & \text { Areia } \\ (0-10) & & & \\ (10-20) & 29,78 & 41,96 & 23,91 \\ (20-30) & 37,41 & 31,24 & 24,77 \\ (30-40) & 35,49 & 39,78 & 22,73 \\ & 37,33 & 40,27 & 22,19\end{array}$

AREA 3 - SOLO NATURAL DA MATA SUBTROPICAL

$\begin{array}{cccc}\begin{array}{c}\text { Profund. } \\ \text { (cm) }\end{array} & \text { Argila } & \text { Silte } & \text { Areia } \\ (0-10) & 19,58 & 61,99 & \\ (10-20) & 26,41 & 51,22 & 10,56 \\ (20-30) & 49,67 & 34,52 & 18,85 \\ (30-40) & 53,04 & 26,12 & 7,8 \\ (40-50) & 55,28 & 16,62 & 12,03 \\ & & & 21,15\end{array}$


ANALISES GRANULOMETRICAS

TABELA 2

AREA 4 - SOLO NOVO REVEGETADO COM BRACAATINGA HÁ 6 ANOS

Profund.

(cm)

0-10

10-20

20-30

$30-40$

40-50
Argila

26.62

7.14

5.20

4.99

6.53
Silte

32.97

40.28

45.49

53.87

42.01
Areia

34,73

49.52

47.45

39.36

48.17

AREA 5 - SOLO NOVO REVEGETADO HA 7 MESES

Profund. (cm)

0-10

10-20

20-30

30-40

40-50
Argila

44.06

39.16

35.80

43.65

42.22
Silte

19.05

25.49

29.14

25.20

23.97
Areia

33.50

32.96

27.21

28.43

27.63

AREA 5 - SOLO NOVO REVEGETADO HA 2 ANOS

Profund.
(cm)
$0-2$
$2-10$
$10-20$
$20-30$
$30-40$
$40-50$

Argila

37.12

46.10

39.98

29.27

46.00

46.92
Silte

27.95

23.72

30.18

39.22

24.31

22.58
Areia

26.18

30.82

23.41

24.34

25.38

24.40

AREA 5 - SOLO NOVO REVEGETADO HA 3 ANOS

Profundidade

(cm)

0-10

10-20

20-30

30-40

40-50
Argila

36.11

19.07

28.97

32.74

35.70
Silte

33.06

22.43

19.37

25.62

25.87
Areia

25.57

55.39

48.00

38.06

34.50 
ANALISES GRANULOMETRICAS

TABELA 3

Area 6 Solo novo revegetado com mudas e forragem ha 7 meses

$\begin{array}{llll}\begin{array}{l}\text { Profunid. } \\ (\mathrm{cm})\end{array} & \text { Argila } & \text { Silte } & \text { Areia } \\ 0-10 & & & \\ 10-20 & 50.08 & 27.36 & 17.80 \\ 20-30 & 45.08 & 36.45 & 15.58 \\ & 51.91 & 23.55 & 17.86\end{array}$

Area 6 Solo novo revegetado com Eucaliptus ha 19 anos

$\begin{array}{llll}\begin{array}{l}\text { Profund. } \\ (\mathrm{cm})\end{array} & \text { Argila } & \text { Silte } & \text { Areia } \\ 0-2 & 30.19 & & \\ 2-10 & 50.89 & 41.67 & 19.79 \\ 10-20 & 52.83 & 22.06 & 14.84 \\ 20-30 & 56.20 & 30.96 & 11.74 \\ 30-40 & 48.55 & 32.40 & 8.83 \\ 40-50 & 39.98 & 42.41 & 7.00 \\ & & 30.18 & 23.41\end{array}$

Area 7 Solo novo aplainado e revegetado com mudas ha 7 meses

$\begin{array}{llll}\begin{array}{l}\text { Profund. } \\ (\mathrm{cm})\end{array} & \text { Argila } & \text { Silte } & \text { Areia } \\ 0-10 & & & \\ 10-20 & 24.37 & 45.19 & 27.68 \\ 20-30 & 13.66 & 48.97 & 32.67 \\ 30-40 & 13.26 & 51.56 & 38.48 \\ 40-50 & 16.42 & 42.01 & 40.74 \\ & 15.50 & 44.34 & 37.62\end{array}$

Area 7 Solo novo uso de "mimosoide" apos 2 anos

$\begin{array}{llll}\begin{array}{l}\text { Profund } \\ \text { (cm) }\end{array} & \text { Argila } & \text { Silte } & \text { Areia } \\ 0-10 & & & \\ 10-20 & 29.27 & 39.87 & 26.05 \\ 20-30 & 38.45 & 35.73 & 17.42 \\ 30-40 & 47.32 & 29.71 & 22.07 \\ 40-50 & 51.30 & 30.35 & 18.03 \\ & 49,26 & 35.97 & 11.77\end{array}$


ANALISES GRANULOMETRICAS

TABELA 4

Area 8 Solo novo area-piloto apos 7 meses

$\begin{array}{llll}\begin{array}{l}\text { Profund } \\ (\mathrm{cm})\end{array} & \text { Argila } & \text { Sitte } & \text { Areia } \\ 0-2 & & & \\ 2-10 & 31.11 & 37.63 & 21.89 \\ 10-20 & 40.80 & 32.36 & 19.48 \\ 20-30 & 45.49 & 26.14 & 19.39 \\ 30-40 & 46.20 & 27.20 & 21.33 \\ 40-50 & 45.69 & 20.98 & 19.92 \\ & 28.76 & 41.67 & 26.56\end{array}$

Area 8 Solo novo revegetado ha 7 meses

Profund.

(cm)

$0-2$

Argila

Silte

Areia

2-10

40.08

32.83

19.59

$10-20$

0.41

34.23

16.46

41.31

34.24

17.59

40.69

33.27

18.77

33.76

35.91

37.33

40-50

21.52

41.74

30.98

Area 8 Solo novo revegetado ha 3 anos

Uso de serapilheira

$\begin{array}{llll}\begin{array}{l}\text { Profund. } \\ (\mathrm{cm})\end{array} & \text { Argila } & \text { Silte } & \text { Areia } \\ 0-10 & 28.66 & 33.64 & \\ 10-20 & 18.05 & 38.82 & 34.77 \\ 20-30 & 46 & 31.82 & 42.26 \\ 30-40 & 38.96 & 33.53 & 19.51 \\ & & 27.33\end{array}$

Top-Soil usado para revegetar area 8

$0-20 \mathrm{~cm}$

51.20

27.06

12.57 